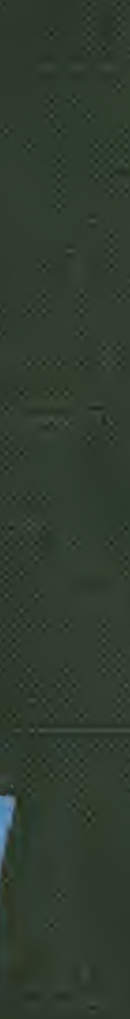

lifornia ional ity 
NOV 1932

N. Y.S. L.

aut.

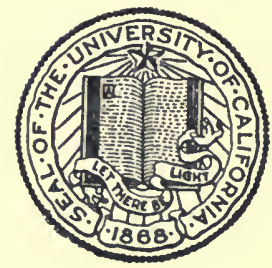

THE LIBRARY

OF

THE UNIVERSITY

OF CALIFORNIA

LOS ANGELES 

Digitized by the Internet Archive in 2007 with funding from Microsoft Corporation 
AGRICULTURAL EDUCATION IN THE PUBLIC SCHOOLS 
THE UNIVERSITY OF CHICAGO PRESS CHIOAGO, ILLINOIS

Agents

THE BAKER \& TAYLOR COMPANY NEW YORK

THE CAMBRIDGE UNIVERSITY PRESS LONDON AND EDINBUROE 


\section{Agricultural Education in the Public Schools}

A Study of Its Development with

Particular Reference to the

Agencies Concerned

BY

BENJAMIN MARSHALL DAVIS

Professor of Agricultural Education in Miami University

WITH AN INTRODUCTION BY

CHARLES HUBBARD JUDD

Director of the School of Education

The University of Chicago

THE UNIVERSITY OF CHICAGO PRESS

CHICAGO, ILLINOIS 
Copyright igiz By

The University of Chicago

All Rights Reserved

Published March 1912 


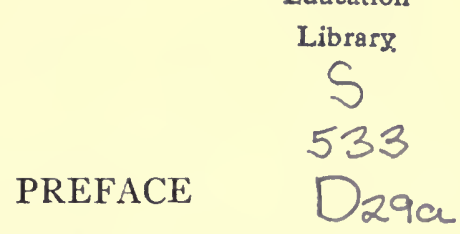

This work comprises a series of studies, carried on since the fall of I909, on agricultural education in the elementary and secondary schools of the United States with special reference to the various agencies promoting it. Much care has been taken to make the bibliography representative of the literature of the different phases of the subject, and to annotate each title so as to give the reader a brief account of the original article or book. This seemed more essential than to undertake to give even an approximately complete summary of the literature of the subject, especially since such a summary would include many times the number of titles cited.

The writer has attempted, as the subtitle indicates, to bring together the work of the various agencies promoting agricultural education in the public schools, and to show the contribution each has made or is making to its development. In this new and rapidly developing subject of education it is important for all who are interested to know the methods used and results obtained in different parts of the country, and to recognize the extent of public interest as expressed in federal, state, and private activities in its behalf.

The demands for instruction in agriculture in elementary and secondary schools have grown so rapidly as to present a serious problem to teachers, both as to readjustment of their school work and as to their own preparation to teach the subject. If this account of the development of agricultural education, such as is actually taking place in different parts of the country, with illustrations of types of instruction, and with sources of further information, may be of some service to the teachers of our rural schools, or to others interested in rural education, the writer will feel well repaid for all his efforts.

The material for these studies has been gathered from all 
available sources, much of it from personal correspondence. The writer wishes to express his appreciation of the cordial and ready response with which his numerous inquiries have been met. $\mathrm{He}$ is under particular obligation to Director Charles $\mathrm{H}$. Judd, School of Education, the University of Chicago, for writing the introduction, and for his many helpful suggestions during the progress of the work; to Mr. D. J. Crosby, United States Department of Agriculture, for the critical reading of several chapters, and for other assistance; to the United States Bureau of Education, to the State Departments of Education, and to many individuals who have furnished information not otherwise accessible.

Benjamin Marshali Davis

Miami University, Oxrord, OHo

March, I9r2 


\section{TABLE OF CONTENTS}

INTRODUCTORY NOTE

PAGE CHAPTER

I. The United States Departient of Agriculture a 7

II. United States Bureau of Education . . . . . 14

III. State Departments of Education and State LegislaTION . . . . . . . . . . . . . . . . 19

IV. Summary of State Legislation and of Work of State Departments of Education for igio-i . . . . 27

V. Agricultural Colleges, Including Extension Work, Departments of Agricultural Education, and Summer SCHOOLS FOR TEACHERS . . . . . . . . . . 38

VI. State Normal Schools . . . . . . . . . . 47

VII. National Education Association-State and Other Teachers' Associations . . . . . . . . . . 58

Viti. Educational Periodicals . . . . . . . . . . 67

IX. Periodical Literature . . . . . . . . . 75

X. State Organizations for Agriculture-Farmers' INSTITUTES . . . . . . . . . . . . . . 85

XI. Agricultural Societres . . . . . . . . . . 94

XII. Boys' Agricultural Clubs . . . . . . . . 105

XIII. Elementary and Secondary Schools . . . . . II5

XIV. Textвoокs . . . . . . . . . . . . . . . $\mathrm{I} 27$

BIBLIOGRAPHY . . . . . . . . . . . . . . . $\mathrm{I}_{32}$

INDEX . . . . . . . . . . . . . . . . . . I6I 



\section{INTRODUCTORY NOTE}

Agricultural education is the most widely and energetically cultivated form of industrial education in this country at the present time. Federal and local grants have made possible agricultural courses of different grades, and there is a large body of literature relating to scientific agriculture. This development of agricultural education is due, in the first place, to the large number of people who are dependent upon agriculture for their livelihood. Any improvements which can be made in the methods of raising crops or live stock are of immediate importance to a large body of American citizens. In the second place, the economic value of the products of agriculture has made it important for the community at large to organize agencies which shall improve agricultural conditions throughout the country. Even the federal government has found it expedient to organize bureaus of investigation, and these bureaus of investigation have naturally come to be centers of educational activity. There have thus arisen organized centers for the collection and distribition of agricultural information. In the third place, the social movement which has been carrying the population in very large measure away from rural districts to the cities has made everyone aware of the necessity of developing an educational system that shall make farm activities attractive to intelligent and well-trained people. Finally, students of education have come to see that the needs of children, quite apart from the needs of society at large, dictate a greater emphasis upon outdoor experiences. The doctrine that children need to come into contact with Nature has been presented in different ways at different times. On the negative side it has been said that children should be taken away from books and from the artificial surroundings of large communities and should be brought into contact with things and natural laws. This, 
we are told, can be accomplished best on the farm. Again, on the affirmative side, it has been said that the resourcefulness of the man who is engaged in the various occupations of the farm cultivates breadth of character and initiative in dealing with all the engagements of life. Whatever the terms employed, the professional educator has come to regard the opportunities which are presented in farm life as valuable means of training children.

With the recognition of these numerous and strong motives for the development of agriculture as a part of the educational system, there comes a whole train of difficult problems of organization. Even those who recognize the importance and value of agricultural education are in doubt as to the best methods of attaining the result that they regard as ideal. One of the first questions that arises is the question of the level of training at which agricultural courses shall be introduced. Is the study of any phase of farming a suitable subject for elementary school children, and, if so, what simple elements of the subject can properly be taught at this early stage of school work? On the other hand, the problem of finding suitable agricultural courses for higher institutions is no less difficult. The agricultural colleges have found themselves in frequent conflict with the traditional colleges. The agricultural colleges have sometimes been criticized for conducting a lower grade of work than that which is conducted by other institutions of higher learning. In spite of these criticisms, in some quarters the agricultural courses have developed to such an extent that the conventional academic courses have almost disappeared from the institutions in the state. In either of these cases the difficulty of organizing advanced work is manifest. It has sometimes been suggested that the agricultural high school is a better means of promoting agricultural education than is the elementary school or the university. When an agricultural high school has been organized it has degenerated at times into an ordinary high school with one or two theoretical courses in agriculture. 
In other cases the agricultural high school has differentiated itself so completely from the conventional high school that the students who graduate from these separate and distinct institutions have been unable to go forward to higher institutions. All of these cases show the difficulty which is encountered in organizing the work in agricultural education.

One of the cardinal difficulties in the organization of agricultural education is the lack of trained teachers. Teachers who have grown up in the normal schools or those who go into the profession from colleges and high schools without a normal training, very seldom have practical experience adequate to give them a comprehension of farm problems. On the other hand, those who have practical experience find it difficult to secure the scientific training which is necessary to make instruction in farming sufficiently advanced to justify calling it a science. The graduates of agricultural colleges are either so much in demand for practical positions, or so poorly qualified for the special work of teaching, that they do not enter upon the teaching profession after they complete their agricultural course. The result of this whole situation is that there are many efforts being made to teach agriculture from textbooks, and these efforts are being criticized by practical people and educators alike as too abstract. In other quarters instruction lacks that systematic and progressive character which can come only from the study of the sciences upon which farming must ultimately rest. Practical farmers are no better teachers than the abstract students of textbooks. The situation requires a careful correlating of the different agencies that have been working in the direction of a more scientific and at the same time more practical course of study in agriculture.

Professor Davis has attacked the problem of the co-ordination of all the agencies now at work on the problem of agricultural education. He has performed in this book a service which will be appreciated by all who have any large knowledge of the problem and of the difficulties which the movement en- 
counters. He has made an effort to canvass the whole field of agricultural education and to give a detailed exposition of the agencies that are now at work in building up a rational course of agricultural education. $\mathrm{He}$ has presented more fully than anyone else the materials which define the problem and which make it possible for the teacher to meet the problem intelligently. The annotated bibliography at the end of the book, with text references, will do much to make the best material available for anyone who finds it necessary to get hold of this material through independent study. Mr. Davis' statement of the work that is being done by various organized agencies will make it possible for the teacher to come in contact with all of the forces that are working to build up this special type of training. The book serves, therefore, as a general introduction to the study of agricultural education.

Professor Davis' book is not a textbook of the ordinary type, in which a limited body of materials is presented in detail. but it is a type of textbook which is certain to becone more common in our normal schools and in the teachers' libraries. It is a textbook which discusses the problems of education by discussing the situation into which education fits and the instruments that may be used in solving its problems. It is an introductory encyclopedia rather than a brief summary. The student in the normal school who is trained not merely to understand the content of a single texthook, but to take a bibliography in hand and follow its guidance into the larger body of literature, will have an independent mastery of the strbject which cannot be gained by any simple perusal of a single textbook. Professor Davis has performed a genuine service, therefore, for normal schools in preparing a type of textbook which encourages the student to go to the original sources, and shows him how to get at the different types of material which he will need in his own practical professional life.

The teacher who has graduated from the normal school and is in practical service often finds the textbooks that are offered 
for his instruction too elementary and too closely confined to the kind of material with which he has already acquainted himself in earlier courses prior to his work as a teacher. Such a book as that which Professor Davis has here presented overcomes the difficulties which attach to the reading of such an elementary book. He has opened up for the teacher not merely the possibilities of reading his own book, but also the possibility of securing without serious difficulty an extensive body of productive literature to which this book serves as a stimulating introduction.

Finally, the professional student of education will find in this book material which will give him a general view of one phase of industrial education that will be very helpful to him in the discussion of the whole matter of educational reform for practical results. If one wishes to discuss the best methods of organizing courses for the industrial classes he should certainly begin 'with a careful review of that which has already been undertaken in agriculture. There are some bibliographies of agricultural literature, and there are scattered discussions of the different organizations which deal with this problem, but nowhere is there a carefully selected summary of the whole movement. Professor Davis has in this respect performed a service which will be appreciated by students of education and by the later historian of education who wishes to secure in compact form a statement of what is now being undertaken.

Chicago

Chas. H. Judd

March, I9I 2 



\section{CHAPTER I}

\section{THE UNITED STATES DEPARTMENT OF AGRICULTURE}

Historically the movement for agricultural education in the United States dates back to 1785 when associations for the promotion of agriculture began to be formed. A few years later, in $\mathrm{I} 792$, mainly in response to the agitation of these associations, colleges undertook to provide for instruction in agriculture, first Columbia, and then Harvard and Yale (I). ${ }^{1}$

It was not, however, until 1862 that the real movement for scientific agriculture had its beginning. Congress of this year authorized the establishment of a department of agriculture (2, p. 57), and also passed the Morrill Act giving to each state a grant of land with which to establish a state college of agriculture and mechanic arts (2, pp. 62-64). The Hatch Act of I887 provided for agricultural experiment stations in each state and territory (2, pp. 64-66), and during the following year the Office of Experiment Stations was created as a separate bureau of the Department to serve as the official head of all the agricultural experiment stations.

On July I, I862, the United States Department of Agriculture was organized. Its growth as expressed in terms of people employed and total expenditures may be seen by comparing 29, the number employed the first year, with 17,819 , the number employed in 1908 , and $\$ 63,704.2$ I expended the first year with $\$ 13,628,696$ expended in I908. For the last twenty years Congress has provided liberally for the maintenance of the Department. It has been estimated that nearly $\$ 100,000,000$ has been spent during this time for agricultural research and education, for the most part through the Department. This vast expenditure, of course, would never have been made had it not

'Figures in parentheses refer to corresponding numbers in the annotated bibliography, p. 132 . 
been justified by results as measured in dollars and cents. In I908 the agricultural products of our country amounted to $\$ 7,778,000,000$. The value of the corn crop alone amounted to

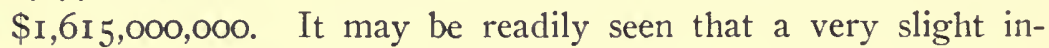
crease in yield per acre would aggregate many times the running expenses of all the institutions engaged in promoting agriculture. The work of the Department has made possible not only a slight increase but in nearly all kinds of production a very large increase (2, pp. 44-46).

The aim of the Department has been twofold: first, scientific, developing a scientific knowledge of every phase of agriculture; second, educational, conveying this knowledge to all the people. In both these aspects of its work the Department has been closely allied with the land-grant agricultural colleges. Indeed, the Department and the agricultural experiment stations in different states and territories, organized chiefly as departments of land-grant colleges, stand at the head of our system of agricultural research and education.

Since "I 889 the Association of American Agricultural Colleges and Experiment Stations has been holding annual meetings. Members of the Department take prominent part in these meetings, and the proceedings are published through the Office of Experiment Stations. The director of this office is chairman and the specialist in agricultural education is secretary. The educational policy of agricultural colleges, such as terms of admission, courses of study, matters of administration, etc., is determined largely by a standing committee of this association known as the "committee on instruction in agriculture." For several years agricultural instruction of collegiate grade has been well organized and on a good working basis. Recently the efforts of this committee have been directed to a consideration of instruction of secondary grade. A course of study has been worked out in considerable detail to serve as a model for schools contemplating such instruction $(3,4)$. Some attention has also been given to work in elementary schools $(5,20)$. 
The Department is organized into eleven scientific bureaus as follows: weather, animal industry, plant industry, forest service, chemistry, soils, entomology, biological survey, statistics, experimental stations, and public roads. All of these are doing much to encourage and help agricultural education throughout the country. In a general way they reach the people through publications, a great many of which are distributed free $(6,7,9)$ while others are for sale at a nominal price $(7,8)$. Those for free distribution are as a rule written in a popular style, free from technical terms, and are easily understood by the average reader. The series known as "Farmers' Bulletins" contains contributions from all the bureaus and there is scarcely any phase of agriculture that has not received attention. These bulletins are especially useful to elementary and secondary schools giving instruction in agriculture ( 7 ). Many of them dealing with such subjects as birds, insects, tree planting, school gardening, and plant propagation would be useful in any elementary or high school.

Besides general contributions to agricultural education made by all the bureaus of the Department, certain bureaus are taking an active part in public education.

The Weather Bureau from its central office at Washington and through its officials at various stations throughout the country is doing much to encourage the study of meteorology.

During the school year a million or more children of the public schools make weather observations and study the daily weather maps and forecasts. From its earliest days the Weather Bureau has co-operated to some extent in public-school work, and during the past ten years this co-operation has been widely extended. The public schools and the Weather Bureau have a mutual interest in the matter. The school authorities have found in the study of the weather with the assistance of the Weather Bureau a means of satisfying part of the requirements of modern methods of study; and the Weather Bureau is able through the school gradually to dispell popular superstitions and fallacious beliefs that have hampered its work .... and to enable both the commercial and the agricultural world to make more intelligent and more complete use of the forecasts, special warnings, weather maps, and climatological publications (ro, p. 267). 
About 15 per cent of the daily issue of weather maps is used in the public schools. Lectures are given by officials of the Weather Bureau at teachers' institutes and elsewhere. The policy of this bureau has been to assist the public schools in every way possible as far as general duties to the public will permit.

The Forest Service is reaching the schools through its publications, lantern slides, and other illustrative material concerning the conservation of the forests of our country. The Forest Service believes that "the public school should treat forestry as one of the important economic and public questions in the life of the world" (II, p. 6), and that forestry should have a prominent place in our education. "Below the secondary school forestry should form part of nature-study, arithmetic, and general geography; in the high school, of United States history, civics, physical geography, commercial geography, botany, agriculture, and woodworking" (II, p. 7). One of the recent efforts of the Forest Service to co-operate with the public schools is through phenological studies of our native forest trees. On request the Forest Service will send to any school a set of blanks on which to record observations on such matters as general character of country, situation of trees, character of season, date of swelling of buds, of bursting of buds, of beginning of leafing out, of general leafing out, of blossoming, of change of color in foliage, etc. (dates of fifteen special observations in all). These blanks are accompanied by a circular giving complete directions for study of trees and making records. This work is of great value not only in encouraging pupils to make a close acquaintance with trees, but also in the reaction that must come to them in feeling that they are materially assisting the government in its work. Similar phenological studies of common flowering plants have been carried on very successfully for a number of years by the public-school children of Canada under the direction of the Botanical Club of Canada. Suggestions for forest nurseries for public schools have also been prepared 
by the Forest Service (12). Directions are given in considerable detail showing just what to do to establish a nursery in connection with an average school. Three other publications are soon to be issued: Forestry in Nature-Study, Forestry in Agriculture, and Forestry in Geography.

The Bureau of Plant Industry has been especially active in promoting the movement for school gardens. At Washington, under direct supervision of the Bureau, experiments in school gardening have been carried on for several years. A part of the government grounds with a greenhouse has been devoted to this work. The Bureau sends to schools throughout the country special packages of vegetable and flower seeds accompanied by circulars containing directions for planting and care of school gardens (13, 14). The Bureau also furnishes sets of one hundred samples of seeds of economic and wild plants put up in glass vials, labeled with Latin and common names and arranged in an herbarium tray for reference purposes. The seeds and the work of preparation are furnished by this office free of charge, but it is necessary for those desiring sets to supply the tray and vials used. These can be obtained at a cost of \$1.50 from Messrs. Mackall Bros., 9th and H Streets, N.E., of this city [Washington, D.C.], to whom remittances should be made direct with the request that the material be forwarded to this office. At the same time kindly notify us that such remittance has been made. ${ }^{2}$

Another phase of the work of this bureau is of especial interest because of its remarkable development during igro and I9II. This is the Junior Demonstration Work among the boys of the southern states (I5). A brief summary of this work is given in chap. xii.

The following is a good summary of the educational work of the Office of Experiment Stations :

While the other bureaus of this Department are doing valuable educational work along the lines of research in which they are engaged the Office of Experiment Stations is the general agency of the Department for the promotion of agricultural education throughout the United States and is constantly enlarging the scope and extent of this branch of its work.

-From circular letter: "Seed Laboratory," Bureau of Pant Industry, United States Department of Agriculture. 
The educational work of this Office is now organized into two branches, one dealing with agricultural colleges and schools and the other with farmers' institutes and other forms of extension work in agriculture. The work of the Office relating to agricultural colleges and schools includes four general classes: (I) The collection and publication of information regarding the progress of agricultural education at home and abroad; (2) studies of different grades of American and foreign schools in which agriculture is taught; (3) work in co-operation with the Association of Agricultural Colleges and Experiment Stations and other important associations dealing with educational matters; and (4) the giving aid to agricultural colleges and local school authorities along the lines of agricultural education. This work is in charge of Mr. D. J. Crosby, as specialist in agricultural education.

This branch of the Office conducts a department of agricultural education in the Experiment Station Record ( 17 ), prepares and publishes statistics, courses of study, circulars of information, and other literature relating to agricultural education, aids state and local school authorities in organizing agricultural courses in schools and colleges and in securing competent teachers, takes part in important agricultural conventions and conferences, aids teachers in securing suitable agricultural literature for their work, and, in short, acts as a clearing-house for agricultural education in this country ( 6 , pp. 7, 8).

The work of the Office dealing with farmers' institutes and extension work is in charge of Professor John Hamilton, farmers' institute specialist. Although all the work undertaken by this branch of the Office has to do with agricultural education as presented to adults, it also reaches the public schools indirectly through correspondence with persons interested in agricultural education by distributing agricultural literature, by preparing and editing bulletins, illustrated lectures, and courses of study for movable schools of agriculture (133, I43). In the movable schools of agriculture a course is offered for country school teachers including nature-study, school gardens and grounds, and school architecture, and sanitation ( 18, p. 6).

The attitude and interest of the Department toward unifying our educational system, in so far as it concerns agriculture and country life, into a complete system extending from the elementary schools, through the secondary schools, into the col- 
leges and graduate schools has been well expressed by Assistant Secretary Willet M. Hays in a recent address (19, pp. 4, 5). He says:

A movement is well begun to organize better, as a part of our great American school system, the secondary schools as to meet especially the needs of country life. This movement contemplates that, below and leading to our more than 60 state colleges of agriculture already established, we shall have 300 to 400 agricultural finishing schools-mpractically one in each country congressional district of ten or more counties, either separate or as a strong department of an existing institution.....

But vastly more important is the larger movement to establish a system of consolidated rural and village schools, and of courses in agriculture in town and city schools so near the homes of farm youth that something of instruction in agriculture, in home economics, and in social and civil affairs, as well as in the accepted subjects of a so-called general education, shall be taught to all the boys and girls of the farm. To meet this first need the consolidated rural school in the open country and the consolidation of rural schools about the villages and cities is rising rapidly into prominence along with the vocational high school; and many city and nonpublic schools of secondary and higher grade are seeking to add agricultural instruction to their courses of study. ....

It is conceded that the large and important task of supplying trained teachers for approximately 30,000 consolidated rural schools in our rich rural communities, for thousands of town and city schools, for 100,000 small rural schools in isolated and sparsely settled communities, for 300 or 400 large agricultural high schools, for 150 state normal schools, and for 60 state colleges of agriculture may be taken up in a practical way and solved in one or two decades. The demand and organization for training teachers going forward together will meet with only the usual pioneering difficulties. 


\section{CHAPTER II}

\section{THE UNITED STATES BUREAU OF EDUCATION}

Agricultural education receives the attention of the Bureau of Education in several ways. These may conveniently be grouped under three heads: publications, land-grant colleges, and legislation.

Having little administrative authority except that relating to land-grant colleges the Bureau has confined its efforts mainly to its publications and correspondence. "No other educational office of the world has done so extensive literary work as this office," is the fine tribute paid by the Royal Prussian Commission of 1904 in its report to the Prussian Parliament. The Bureau's publications consist of annual reports, special reports, circulars of information, and bulletins.

The policy of the Bureat toward agricultural education recently expressed by the commissioner applies especially to its publications:

It can do its best I think as a co-ordinating influence. It can bring to the notice of less favored institutions information concerning the experience of more advanced institutions. It can call attention from time to time to the relation of agricultural education to general education. It can survey the educational field and possibly point out dangers to be averted or weak places to be strengthened. It can, finally, discover things that need doing and are not attended to by any other agency, and can see that some part of such lack is supplied. So much as this I hope the Bureau of Education may be able to do for agricultural education. And so much as this, I may say, it will undertake to do as far as its resources will permit $(22$, p. 53).

The Bureau has done much already in two ways: one by bringing to American educators the work of foreign countries, and the other by reviewing the work being done in various parts of this country. Of the former the most important are the accounts of agricultural education in Austria, Belgium, Canada, France, Germany, Great Britain, and Prussia. One of these publications on school gardens deserves special mention (23). 
It contains a very complete historical account of school gardens and has been extensively quoted in the school-garden literature of this country. Of the reviews of work in our own country two are noteworthy. One written at the beginning of the movement for instruction in elementary agriculture is made up chiefly of reprints of leaflets from Purdue and Cornell universities (24). The other, appearing in 1907 , gives an account of the present status of agricultural education throughout the world (25).

The first Morrill Act of 1862 , the second Morrill Act of 1890 , and the Nelson Act of 1907 providing for government aid to agricultural and mechanical colleges are administered by the Department of the Interior (2 I, p. 3I).

The annual payments under the acts of 1890 and 1907 are made on certifications of the Secretary of the Interior, which are based upon the proper expenditure of preceding appropriations. All of these reports required to be made by the act are collected and passed upon by the Commissioner of Education, upon whose recommendation is based the action of the secretary (2r, p. 32).

While the duties of the Commissioner of Education in his relation to land-grant colleges consist chiefly in gathering statistics and making reports to the Secretary of the Interior he has opportunities for making suggestions and recommendations of importance to agricultural education. For example, in his letter of April I7, 1907, to the presidents and boards of control of state colleges of agriculture and mechanic arts he calls attention to a provision of the act of 1907 "providing for courses for special preparation of instructors for teaching the elements of agriculture and mechanic arts" and adds, "With the increasing number of secondary schools of agriculture and of industrial and trade schools, there will arise a considerable demand for specially prepared teachers to give instruction in special branches of study" $(26$, p. 870$)$. In his report of 1908 to the Secretary of the Interior he gives an account of the action of several institutions taking advantage of this provision (27, pp. 740, 74I).

On July I, r909, the Bureau appointed a specialist in landgrant college statistics who is expected also to pay attention to 
the general subject of agricultural education and to be able to furnish information and advice concerning that subject.

The Commissioner of Education holds an important advisory position with reference to any proposed national legislation concerning education, particularly agricultural education. Duringthe sixtieth session of Congress several bills were introduced providing for national aid to education in agriculture and other industrial subjects. Of these the most important were the Burkett bill (S. 3,392) providing for "the advancement of instruction in agriculture, manual training, and home economics in the state normal schools of the United States," and the Davis bill (H.R. 534) providing in a similar way for national aid to agricultural and industrial education in the secondary schools only. The latter was finally revised (H.R. I 8,204) so as to include the provisions of the Burkett bill (S. 3,392).

The Davis bill provides for annual appropriation of "ten cents per capita of the population of each state and territory and the District of Columbia" for aid to maintain instruction in agriculture and home economics in agricultural schools of secondary grade, and an appropriation of one cent per capita to maintain similar instruction in state and territorial normal schools $(24$, pp. $85-87)$.

The large amount of money concerned, and the establishment of separate schools not already a part of our national system of education called for careful study and deliberation. The Bureau of Education was freely consulted in the matter. No one had a clearer insight into the far-reaching influence of the bill, a clearer understanding of its importance upon the economic and educational welfare of the nation, or a greater appreciation of the principles involved in such legislation, than the Commissioner of Education. In a letter dated September 26, 1907, to $\mathrm{Mr}$. Davis he says:

One strong argument in favor of such national aid, when extended to special forms of education which are in special need of encouragement, may be drawn from the workings of the appropriation for support of land-grant colleges, contained in the second Morrill Act of August 30, 1890 . The recent 
effect of the national appropriations under that act has been to stimulate greatly the support of the land-grant colleges by the states in which they are situated.

He calls attention to a provision of the measure giving administrative authority over the appropriations therein provided to the Department of Agriculture, whereas "appropriations which are primarily for agriculture are now administered by the Department of Agriculture, and these which are primarily for education (land-grant colleges) are administered by the Bureau of Education."

I think [he says] as matters now stand this is a good working division, particularly as the relations between the Bureau of Education and the Office of Experiment Stations of the Department of Agriculture are very close and cordial. Educational interests are becoming so strongly unified throughout this country, and in fact in foreign lands, that the present tendency points to unifying of government activities of a purely educational sort, or of predominantly educational sort, under the Office of Education. Another reason for bringing the activities provided in your bill under the Bureau of Education is that they deal not only with agricultural high schools but with high schools of mechanic arts in cities as well. In institutions of both classes, while industrial ends are sought and industrial means employed, the main purpose, as I understand it, is educational.

It seems to me worth considering, also, the question whether it is advisable that rural schools, to which the bill relates, should in all cases be designated as agricultural high schools. There is still a good deal of difference of opinion as to whether high-school work in agriculture may be done to best advantage in general high schools which are properly equipped on the agricultural side, or in agricultural high schools which pay incidental attention to studies other than agriculture. It is likely, in fact, that we shall have institutions of both types for many years to come, and that both of them will do good and efficient work in the promotion of agricultural education. For this reason it seems to me doubtful whether it is wise to limit the distribution of the fund by using the distinctive designation of agricultural high school.

In a letter to Senator Proctor, dated March 4, I908, the whole matter of national aid as proposed by the Burkett bill and by the Davis bill is carefully reviewed. The entire letter should be read in order to form a just conclusion of the Commissioner's position. After citing the difficulties arising from our complex industrial 
situation, both urban and rural, he recognizes the probable need of federal aid in the following words:

For all these reasons (referring to our industrial situation) the problem of a better education of an industrial type, in both country and city, has steadily become more acute. It is extremely doubtful whether these growing needs can be met in the near future in the majority of the states, unless the encouragement of federal appropriations be added to the efforts of the states and of local communities.

While approving the measure in principle he urges "that any forward step which the national government may take in the encouragement of public education should be carefully weighed, and given its proper place in a well-digested general policy." Furthermore, the conditions in several states are widely different, and any bill should be framed with a full knowledge of these differing conditions in order that it may be made sufficiently flexible to accomplish the best results in all parts of the country. In order "to make possible for Congress to act on bills like S. 3,392 with full knowledge of the situation and needs of the country" he recommends that a commission be appointed to make a thorough investigation of the question and "report to Congress on or before January I, I9Io."

Neither the Davis bill nor the Commissioner's recommendation became a law. The bill was an indication of the interest of the country at large in extending agricultural education into the elementary and secondary schools. The attitude of the Bureau of Education was one of accord with the general principles on which the measure was based, but at the same time one of caution, recognizing that national appropriation to agricultural education, when given, should be of the greatest possible service. ${ }^{2}$

' For permission to quote from letters to Congressmen Davis and Senator Proctor, and for other assistance in getting material for this chapter, the writer is indebted to Commissioner Elmer Ellsworth Brown. A portion of his letter to Senator Proctor appears in the Commissioner's Report of 1908.

'The provisions of the Davis bill have been revised and amended and presented at each session of Congress. In its present form (Page bill, 19I2) it has a much wider scope than the original Davis bill. Dr. P. P. Claxton, United States Commissioner of Education, is not only actively interested in the proposed legislation, but is making an active campaign for the betterment of rural schools. 


\section{CHAPTER III}

\section{STATE DEPARTMENTS OF EDUCATION AND STATE LEGISLATION}

Each state or territory has at the head of its school system a central office. This office is administered in most states by a state superintendent or state commissioner of education, and in some states, as in Connecticut, Delaware, Rhode Island, and Massachusetts, by a state board of education through its secretary or commissioner (29).

These state offices vary in details and plan of organization, and somewhat in authority over educational matters, but are alike in essential respects. But however efficient the departmental organizations, the personality and aggressiveness of those in charge count for much in the influence that these offices exert in the educational welfare of their respective states.

It is especially true that the introduction of a new subject of instruction like agriculture may be greatly hindered or promoted by the attitude taken by the state office. If favorable, the subject may be recommended for legislation, it may be put in the course of study, a textbook may be adopted, through personal influence on local boards it may be introduced in certain sections of the state, interest may be aroused by making it a reading-circle subject, special publications may be issued to help teachers who wish to teach the subject, by promoting interest through clubs or other organizations. The main facts concerning the efforts of all the states and territories in the promotion of agricultural education in the elementary and secondary schools through their central offices of education and by legislation are indicated in the following tabulation.

In Delaware interest in agricultural education has not seemed to warrant any attention from its state department of education. Kentucky, although it is an agricultural state, has 


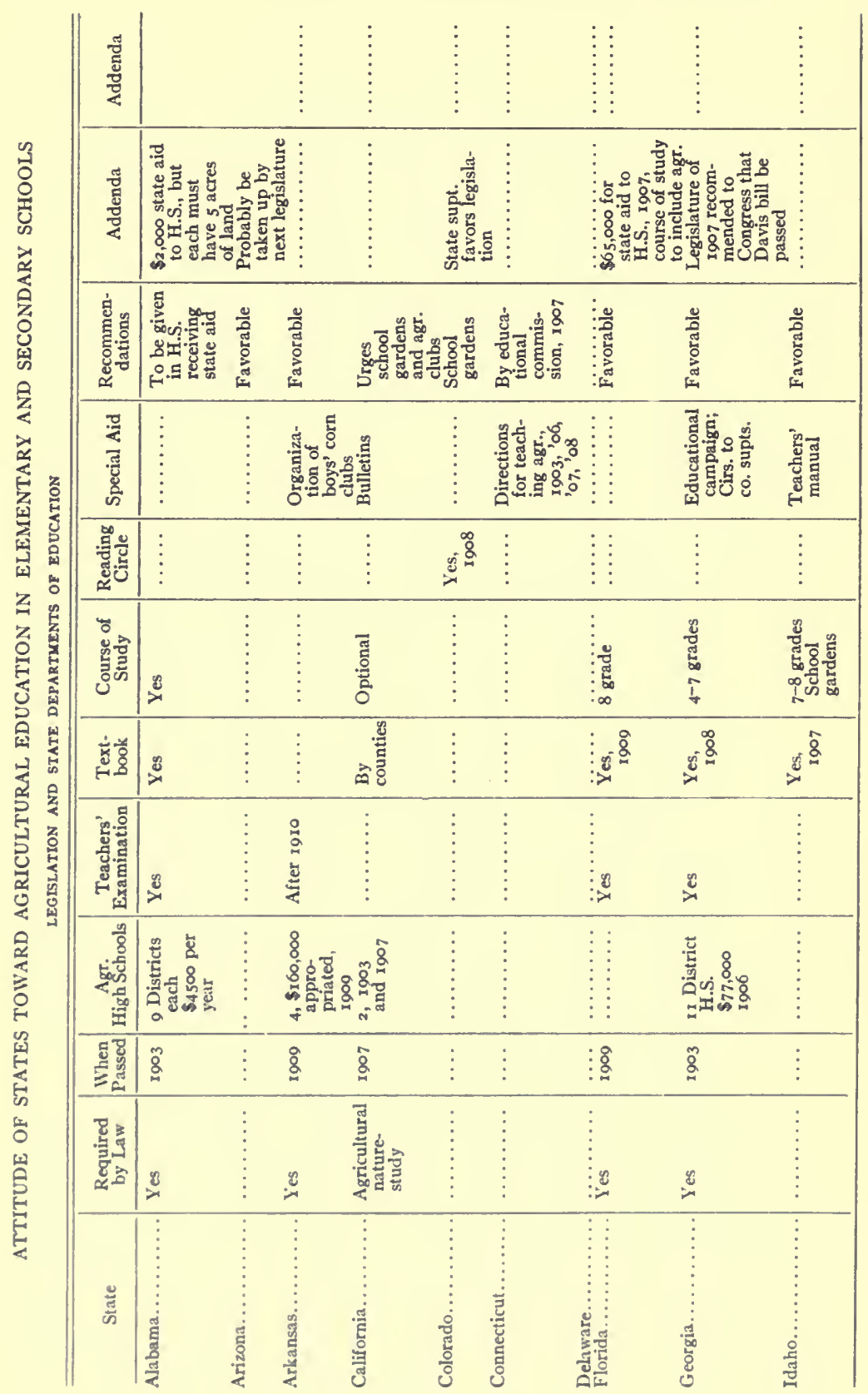




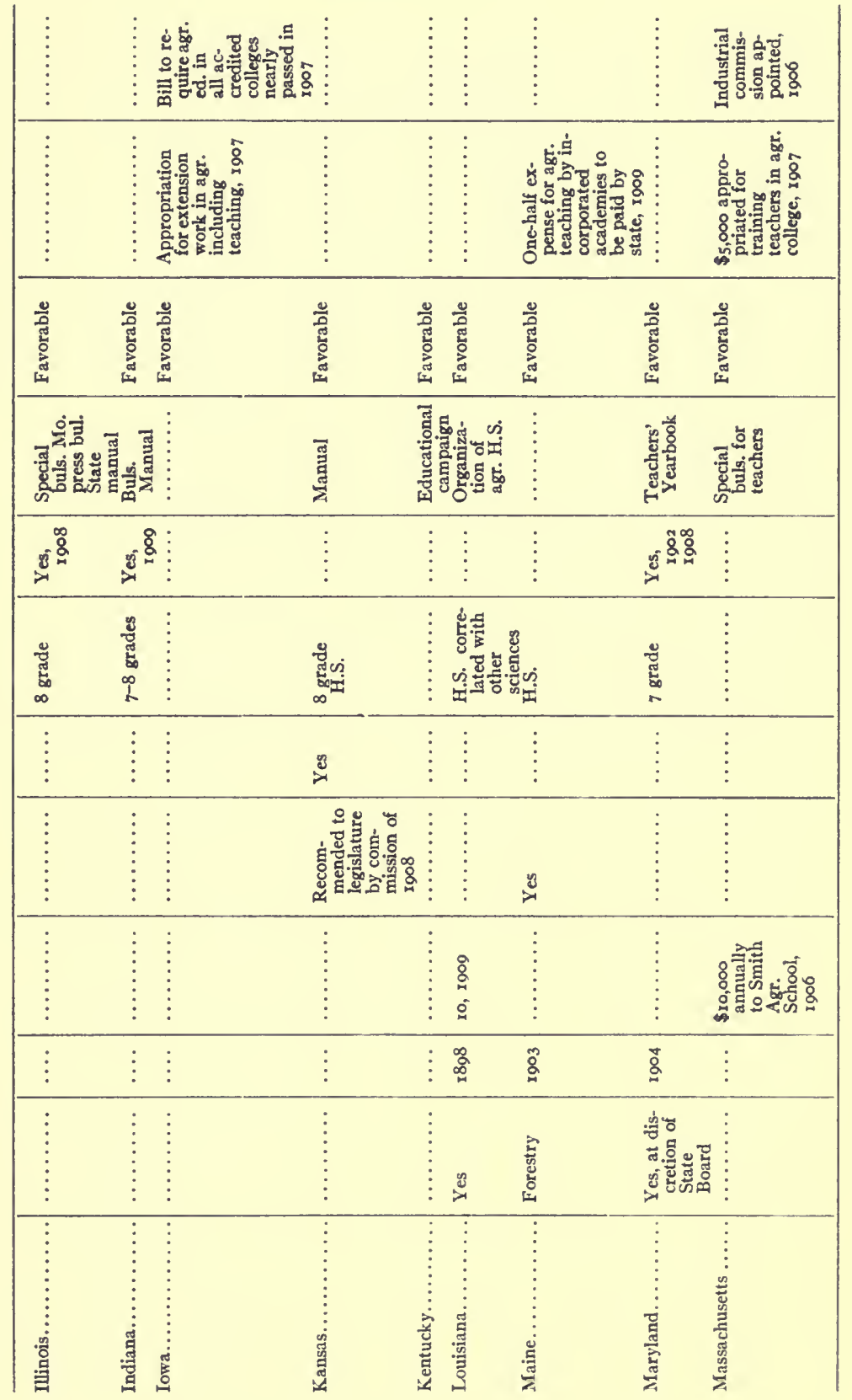




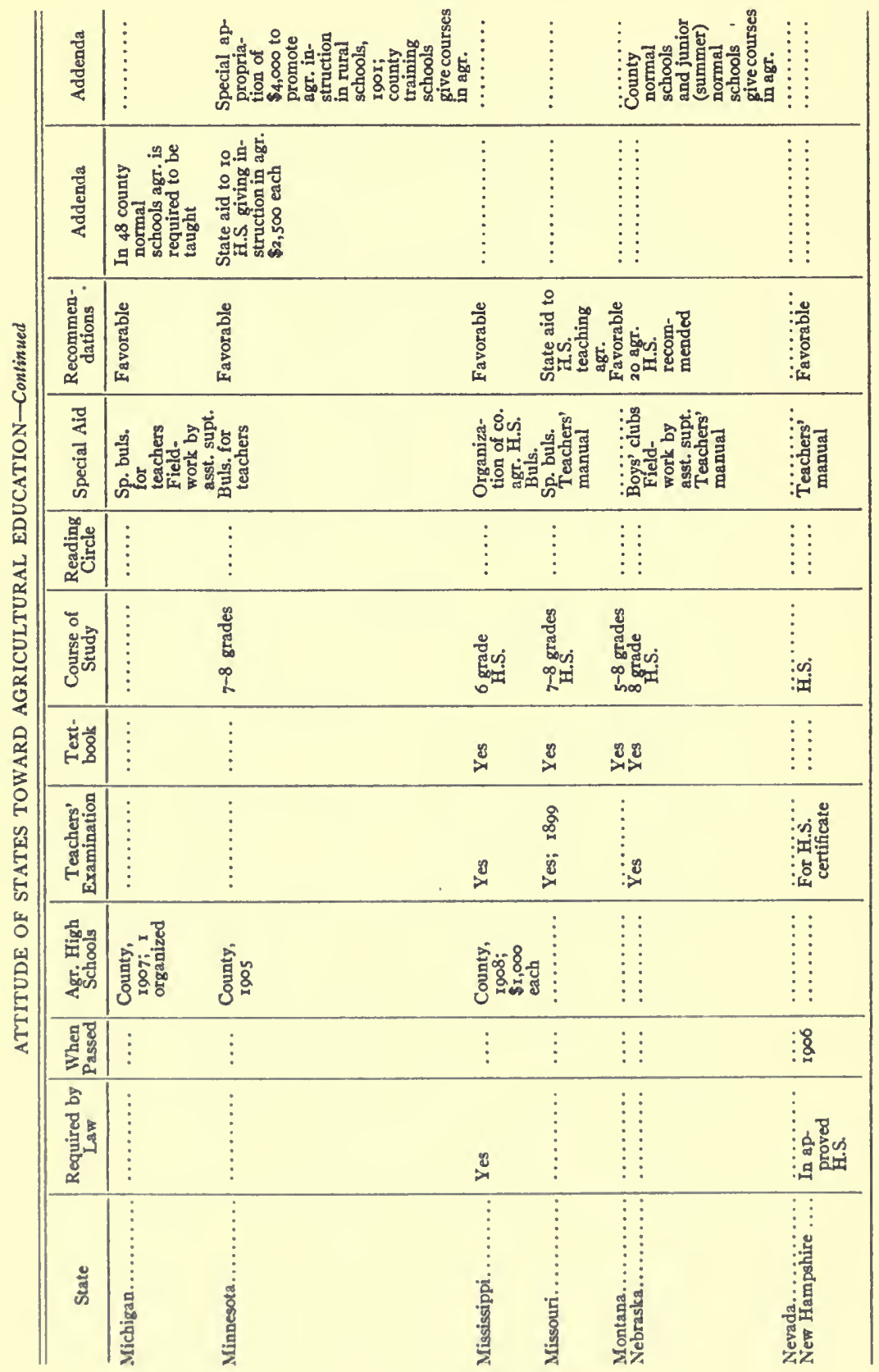




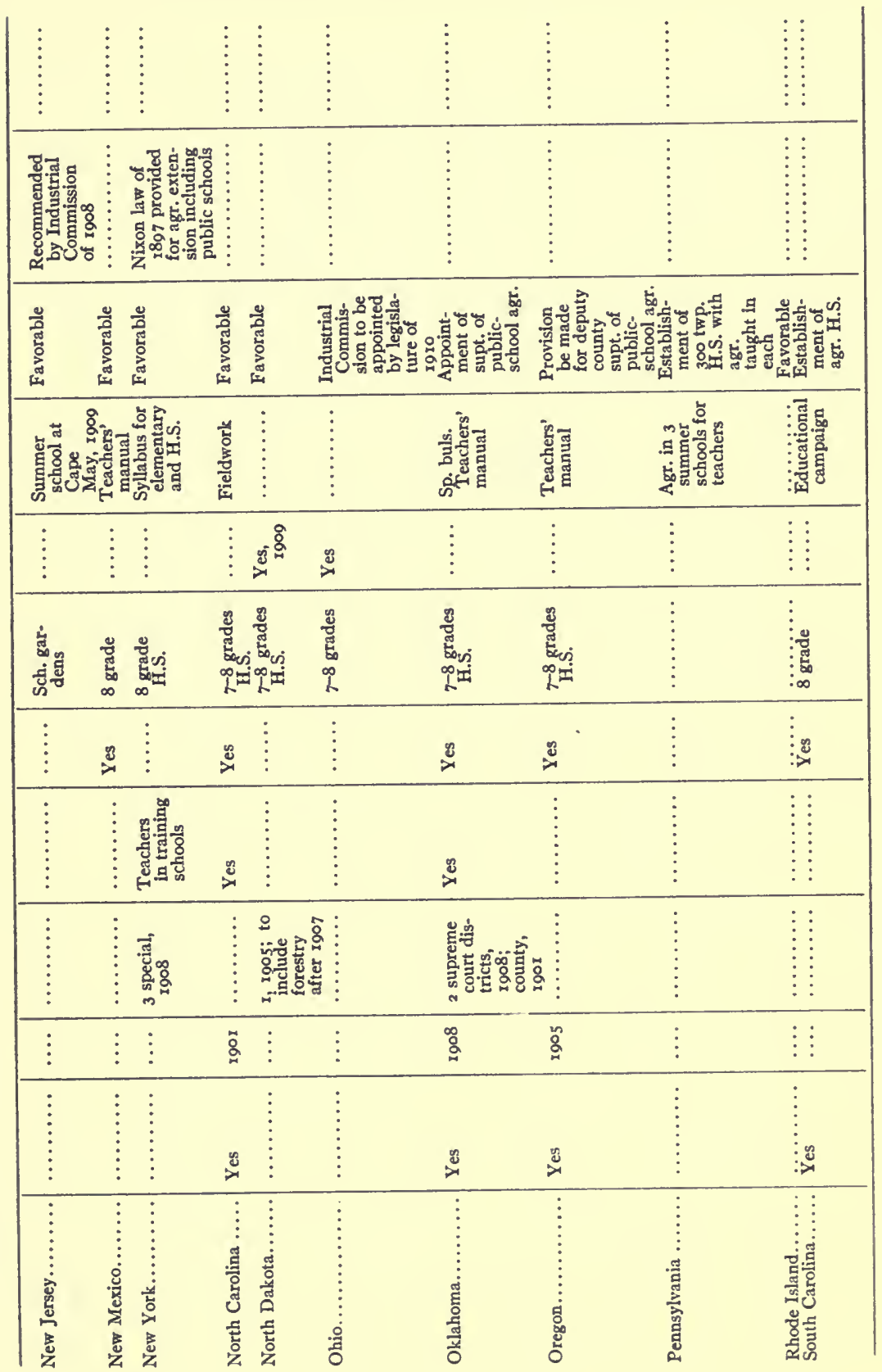




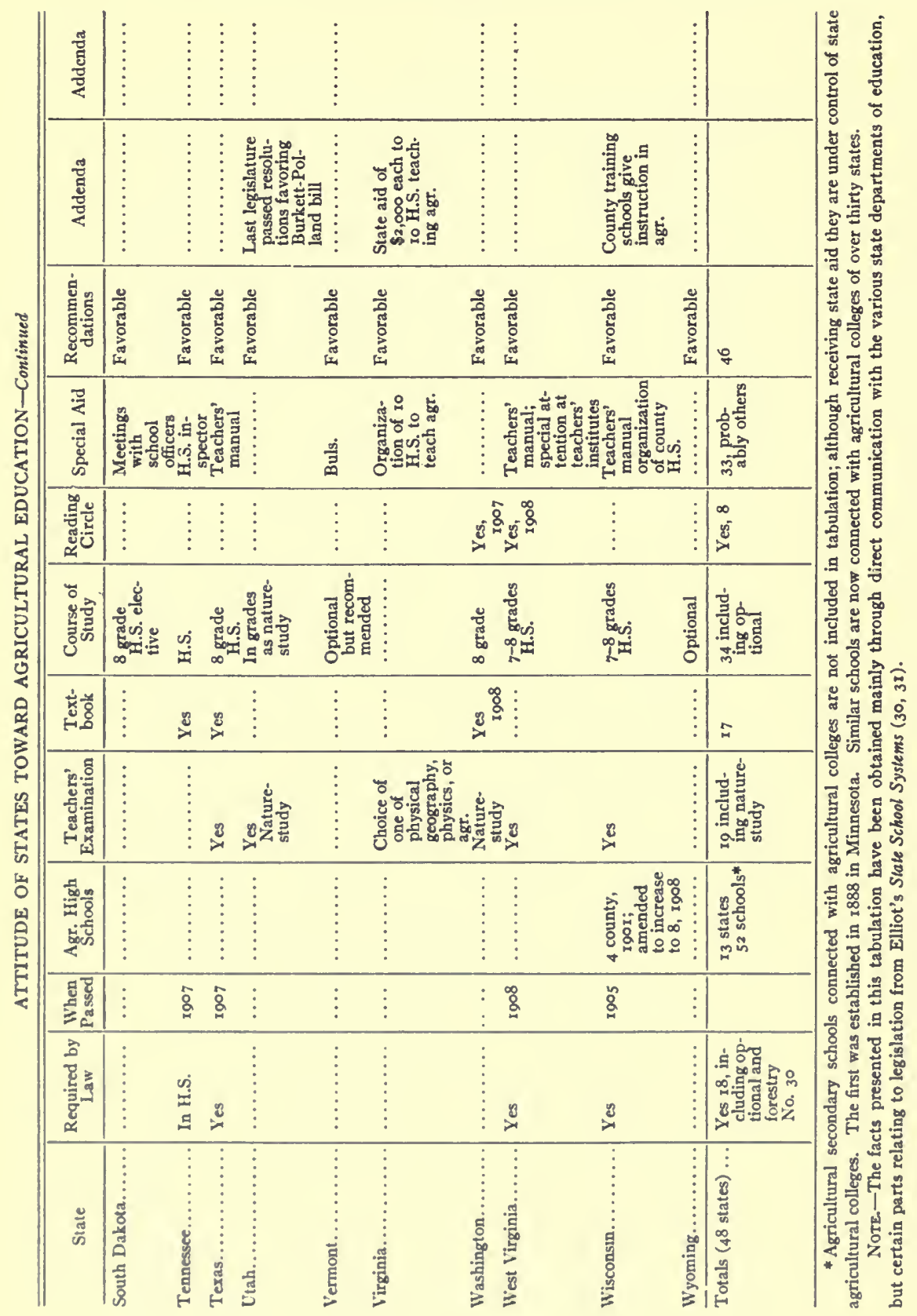


apparently shown much less interest in agricultural education than have other southern states. This may be readily explained by the fact that until I908 the public-school system was organized under the old district plan. The schools were practically controlled by about 25,000 school trustees, 5,000 of whom could neither read nor write. The action of the legislature of 1908 has changed the whole aspect of the Kentucky educational situation, and already remarkable progress has been made toward the improvement of her public schools.

A glance at the tabulation shows that the southern states have been more active (at least recently) in the promotion of agricultural education than the northern states. This activity is a part of the general educational movement extending throughout the South. Educational campaigns have recently been conducted in several of these states and have done much to increase interest in all educational matters.

The earliest legislation concerning introduction of agriculture into elementary schools was the Nixon law of New York in I897 (24, pp. I6Iо--14). It provided for the extension of agriculture into the public schools under the direction of the Agricultural College of Cornell University. It was carried out by means of visits to schools and lectures before teachers' institutes, and by means of teachers' and pupils' leaflets for use in rural schools. The Cornell leaflets not only stimulated much interest in elementary agriculture and nature-study in the state of New York but in other states as well. Similar publications have since been issued by agricultural colleges of several other states.

Requiring the teaching of elementary agriculture by law has not met with unqualified success. In some states where it is supposed to be in force little attention is paid to it on account of lack of qualified teachers. The establishment of state secondary schools of agriculture and provision for state aid to high schools teaching agriculture is probably the most important recent legislation concerning agricultural education. The latter form of state aid seems to be growing in favor. 
Courses of study vary much in their treatment of agriculture as a school subject. The newness of the subject is usually recognized by special directions and suggestions for teaching. These are generally given in a state school manual or handbook for teachers. In some states they are in separate publications. In New York, for example, suggestions are outlined in syllabi, one for elementary schools and one for high schools. In other states bulletins on certain phases of the subject are issued, as in Michigan.

Perhaps the most significant fact showing the widespread general interest in agricultural education in elementary and secondary schools is the attitude of the administrative officers of the various state departments of education. Special mention of the subject is made in nearly all of the latest annual or biennial reports from these offices. In some reports considerable space is given to discussions of industrial education with particular reference to agriculture.

Finally, if any interpretation is to be made of the attitude of state departments of education toward agricultural education it must be remembered that these offices represent the people, and that any policy or action taken is in a certain sense an expression of public opinion. 


\section{CHAPTER IV}

SUMMARY OF STATE LEGISLATION AND OF WORK OF STATE DEPARTMENTS OF EDUCATION FOR I9IO-II

The general discussion in the previous chapter of the attitude of states toward agricultural education in elementary and secondary schools as shown by legislation and state departments of education was based on data collected for the years previous to I9IO. In order to bring the subject up to date, and to show the rate of progress in the development of agricultural education in elementary and secondary schools as expressed in legislation and in the activities of state departments of education the following summary by states is presented:

Arkansas. - The four agricultural high schools provided for by the legislature of 1909 opened in the fall of I9Io with a large attendance. The state provides about $\$ 20,000$ per year for support and maintenance of each of these schools. State aid is also provided for high schools meeting certain requirements fixed by the State Board of Education (Act 328, Laws of I9II). Although the law does not specify that agriculture shall be taught in these schools, the additional support received by them will no doubt enable many to give instruction in this subject as was suggested by the Educational Commission of Arkansas in its report recommending the passage of this act. The state office of education is active in its co-operation with the boys' agricultural-club movement. In addition to the boys' corn clubs already being promoted, rural-school poultry clubs are to be organized in I9I I-I2.

California.-High-school boards may prescribe an additional course, or additional courses of study, "including instruction in manual training, domestic science and art, agriculture, horticulture, and dairying, to be duly credited as part of such high-

${ }^{s}$ Unless otherwise cited the authority for statements made in this chapter is contained in letters received from state departments of education. 
school work" (Cal. Political Code, Sec. I750, May I, I9I I). The state office of education is especially active in promoting agricultural education, co-operating with the college of agriculture of the state university.

Idaho.-Rural high schools are established with agricultural instruction as part of the course of study. The subject of agriculture is put on the list of subjects required in examination for county certificates for teaching.

Iowa.-An act of the last legislature provides for the establishment of departments for training of teachers in agriculture and home economics in forty high schools, and appropriates $\$ 500$ special state aid for each of these schools.

Kansas.-A sum of $\$ 250$ annually is available to such high schools maintaining normal training ${ }^{2}$ as may organize courses in agriculture and domestic science under rules and regulations to be formulated by the state board of education. This provision is also extended to such high schools as may hereafter introduce normal training. A law was also passed requiring an examination in agriculture for all forms of county teachers' certificates.

Louisiana.-During the years I9IO-I I agricultural departments were established in seventeen high schools, and the legislature of 1910 appropriated $\$ 25,000$ per annum for the years I9IO-I I to aid these schools. No more than twenty agricultural departments will be recognized during the sessions of I9IO-I I and I9II-I2. The following is a summary of requirements made by the state board of education for the departments of agriculture of schools receiving state aid: A demonstration farm of at least five acres, which must be tightly fenced, and provided with barn containing full equipment; apparatus for teaching science, with an addition of at least $\$ \mathrm{I} O 0$ worth of apparatus especially for teaching agriculture; at least $\$ 40$ worth of tools and \$I 40 worth of farming implements, and $\$ 250$ for

\footnotetext{
'These departments for normal training in high schools were provided for by previous legislature.
} 
maintenance; the teacher of agriculture must be satisfactory to the state department of education. To aid the department of agriculture and home economics of these schools a course of study, including state requirements for recognition, equipment, courses of study and practicums, has been issued by the state department of education ( 32 ).

Maine.-State aid is given to high schools and incorporated academies maintaining courses in agriculture.

Maryland.-State aid, not to exceed $\$ 2,500$ each, is extended for the encouragement of high schools meeting the requirements set forth by the state board of education. Among these requirements is provision for manual-training and domestic-science courses, and also a commercial or agricultural course, as may be determined by the board of county commissioners. In the suggested course of agriculture for high schools two recitations of forty minutes each and one double laboratory period of eighty minutes are devoted to this subject each week for four years. The course is so arranged that a teacher of agriculture may teach in more than one high school, giving not less than twofifths of his time to schools of the first group, and to no more than four schools of the second group. The sum of $\$ 400$ is available to high schools of each group offering such instruction (School Code and By-Laws of the Maryland State Board of Education).

Massachusetts.-An act of the legislature of I9I I provides for agricultural departments in rural high schools. Such departments must devote their entire time to the theory and practice in agriculture. This work may be elected by pupils in the school. The pupils are to take all their studies except the training in practical farming in the regular classes of the school. The work is to be given by a special instructor who is to devote his entire time to the theory and practice of farming. $\mathrm{He}$ will be expected to supervise certain projects on the farm conducted by pupils, such as gardening, poultry-keeping, orcharding, small animal husbandry, etc., and to give in the classroom 
the applied science, mathematics, etc., that may be necessary in order to bring about the practice of right methods. This teacher is not to teach any of the regular sciences in the school or any other subject save those that may be necessary to the group with which he deals in practical agriculture. The state is to pay two-thirds of the salary of the instructor. The board of education has asked for \$10,000 for the years I9II-I2 in order to test the worth of this scheme. ${ }^{3}$ Some of the details of this plan for part time or project method of agricultural instruction are given in chap. xiii, p. 125. In addition to the Report of the State Board of Education on Agricultural Education (I66) referred to in chap. xiii, the board has issued a bulletin on Agricultural Projects for Elementary Schools (33), the general scheme being the same as for projects for high schools.

Michigan.-The State Commission on Industrial and Agricultural Education appointed by the governor of Michigan in the summer of 1909 has made in its report the following recommendations: (I) provision of at least one high school with a four-year course in each township; (2) introduction as soon as possible of agriculture, manual training, and home economics into all high schools; (3) certification of all teachers of agricultural and industrial subjects; (4) state supervision of all agricultural and industrial courses; (5) state aid for schools introducing high-school courses in agriculture and home economics, as follows: (a) the total not to exceed $\$ 30,000$ for the first year, $\$ 50,000$ for the third year, and $\$ 100,000$ for any subsequent year; $(b)$ an equal division of the funds between agriculture and home economics on the one hand and industrial courses on the other; (c) schools certified for aid in agriculture and home economics to receive $\$ 500$ for the first teacher employed, and $\$ 250$ for each other teacher employed, no school to receive more than $\$ 1,000$ in all (Rpt. Mich. State Com. on Indus. and Agric., I9I0).

'From chap. 47x, Massachusetts Code, and from letter of C. A. Prosser, deputy commissioner of education. 
Minnesota.-Three important laws relating to teaching of agriculture and industrial work were passed by the legislature of I9II :

I. The Putnam Act amends chap. 247, General Laws of I909, providing for state aid of $\$ 2,500$ annually to high schools maintaining agricultural and industrial education, so as to authorize rural schools to become associated with such state-aided high schools. The purpose of this amendment is to provide "training and instruction in such agricultural and industrial departments for pupils in rural schools, and to extend the supervision and influence of state high or graded schools to rural schools; one or more schools may become associated with a high or graded school in which is maintained an agricultural and industrial department as herein provided." Each high school entitled to receive state aid of $\$ 2,500$ per year may receive, in addition, \$I 50 per year for each associated school district, and each, school district forming such an association may receive $\$ 50$ per year (Putnam Act, Laws of I9II). Thirty high schools during I9I I-I 2 will each receive $\$ 2,500$ of state aid. A number of these will receive additional state aid through their association with school districts as provided for in the Putnam Act.

2. "Any high school or graded school which shall maintain such a course as the High School Board of this state shall prescribe in agriculture and either in home economics or in manual training shall receive annually in addition to other aid the sum of $\$ 1,000$ for maintaining such industrial courses, to be appropriated and paid from the appropriation made for state aid to high and graded schools" (Benson-Lee Act, Laws of I9II). About sixty high schools will receive the benefits of this law during the school year I9I I-I2.

3. Encouragement for consolidation of rural schools is extended by the state through the Holmberg Act. Schools are classified as A, B, and C; schools of class $A$ to have at least four departments; those of class $B$, three departments; those of class C, two departments. Each school of class A shall 
receive $\$ 1,500$; of class $B, \$ I, 000$; of class $C, \$ 75^{\circ}$. The principal of each school in any of these classes shall be qualified "to teach the elements of agriculture as determined by the state superintendent of public instruction" (Holmberg Act, Laws of I9II).

Mississippi._. "An act to provide for the establishment of county agricultural high schools and to provide for the equipment and maintenance of the same" was approved March I6, I9Io (chap. I22, Annotated Code of School Laws of Mississippi). According to provisions of this act any town or rural community in a county may bid for the location of an agricultural high school. But no bid will be considered that does not guarantee to the county a donation of at least twenty acres of land, suitable school building, and a dormitory with diningroom facilities to accommodate forty boarders. If no community makes such a donation the above equipment may be secured out of any tax levy made for agricultural high-school purposes. When such a school is established it may receive state aid to the amount of $\$ I, 500$ annually. The state department of public instruction has issued a course of study and general directions for conduct of these schools (34).

Montana.-The superintendent of public instruction urges that the subject of agriculture be given the time assigned to it in the state course of study. In this course the subject is outlined for the pupils of the fifth, sixth, seventh, and eighth grades.

Nebraska.-Although there is no new legislation on agricultural education, considerable interest is shown in the subject of normal training courses (including agriculture) in high schools. A bill somewhat similar to those passed in Kansas and Iowa providing for agricultural instruction in normal training courses in high schools and including state aid was presented at the last legislature, but failed to pass.

Nevada.-Provision is made in the course of study for instruction in agriculture. Three high schools will give courses in agriculture in $19 \mathrm{I} \mathrm{I}-\mathrm{I} 2$. 
New Hampshire.-During the years I9I I-I 2 seven regularly approved high schools will give courses in agriculture. An approved school must employ only graduates of recognized agricultural colleges to give instruction in agriculture. The highschool law of I90I makes it possible to introduce the subject of agriculture into any high school of any community desiring it. In the state course of study for elementary schools agriculture is given a place.

New Jersey.-Legislation relating indirectly to agricultural education is found in the provision made for a state commissioner of education who has, with the consent of the state board of education, the power to appoint four assistant commissioners, one of whom is to devote his time "to the inspection of industrial education, including agriculture."

New York.-In I9Io the state made provision for state aid to high schools giving instruction in agriculture. The sum of $\$ 500$ may be apportioned to any city or union free school district maintaining a school of agriculture, mechanic arts, and home-making for thirty-eight weeks in a year, subject to approval of the state commissioner of education ( 162 ). Twenty schools have definitely adopted the special agricultural course for the year I9II-I2, and will receive state aid. The New York plan is discussed in some detail in chap. xiii, p. I23. In the law of 19 Io relating to agricultural education provision is also made for the training of teachers of agriculture for high schools at the state schools of agriculture at St. Lawrence University, at Alford University, and at Morrisville.

North Carolina.-An act was passed by the legislature of I9I I providing for the establishment and maintenance of county farm-life schools and for the promotion of agriculture and homemaking (County Farm-Life School law, ratified March 3, I9I I). "The aim of said school shall be to prepare boys for agricultural pursuits and farm life and to prepare the girls for home-making and housekeeping on the farm. The course of study in said school shall be subject to the approval of the state superintendent of public instruction and an advisory board in farm-life schools, 
to be appointed by him; Provided, however, that the course of study shall include practical work on the farm, and practical work in all subjects relating to housekeeping and home-making by the girls." The state appropriates $\$ 25,000$ to each school to aid in maintenance and support. The school cannot be located in any city or town of more than one thousand inhabitants, nor within two miles of any city or town of more than five thousand inhabitants. A complete equipment consisting of school building, dormitory buildings, barn and dairy building, a farm of not less than twenty-five acres of good land, and necessary furnishing, apparatus, and farm tools, all of which must be approved by the state superintendent of public instruction. Provision is also made for a high-school department to be maintained in each farm-life school that may not be established at the same place with some existing county high school. In addition to the aim already indicated, it is intended for each school "to conduct agricultural and farm-life demonstration and extension work throughout the country; to hold township and district meetings for the farmers and farmers' wives in all parts of the county from time to time; to co-operate with the county superintendent of public instruction and public-school teachers in stimulating, directing, and supervising farm-life work in the public high schools and elementary schools, and in providing instruction in such work for the teachers through the County Teachers' Association and through special short courses of study for public-school teachers; to provide, also, at said school short courses of study in farm-life subjects for adult farmers and their wives, and to hold at the school county meetings for farmers and their wives for instruction and demonstration work from time to time." Under provisions of this law two counties have voted for such schools, and several more have the matter under consideration and will call elections later.

North Dakota.-Three important measures in the interest of agricultural education became laws in I9I I. Agriculture is made one of four optional subjects in examinations for first-grade teachers' certificates. This will probably be amended later, mak- 
ing agriculture one of the required subjects. State aid is to be given to rural and graded schools. These are of two classes, but among the requirements for both classes are courses in domestic science, manual training, and elementary agriculture. Provision is made for the establishment of county agricultural and training schools. "Each of said schools shall receive state aid in the sum of $\$ 2,500$. . . . Not more than five schools shall be aided the first year nor more than five be added every two years thereafter." A state agricultural and training board is also created. This board "shall consist of the president of the state agricultural college, the state superintendent of public instruction, and three practical farmers, who shall be appointed by the governor of the state.

Ohio.-An act to provide for the teaching of agriculture in the common schools became a law in I9I I, but does not apply to city school districts of the state. The act requires "that the state be divided into four agricultural districts to be mapped out, located, and defined by the commissioner of common schools. ... The state commissioner shall also superintend all such agricultural education designated in this act and shall appoint in each agricultural district a person known as district supervisor of agriculture." Among the duties of this officer are visiting and co-operating with the several boards of education in his district in planning such a course of study in agriculture as they may think best adapted to the needs of the people of the respective school districts; visiting the county teachers' institute in every county in his district, and giving instruction in agriculture to the teachers of the several schools designated in this act; co-operating with the state board of agriculture, and giving the state such time as may be necessary to lecture on agricultural subjects as are related to teaching in the common schools; encouraging county agricultural societies in each county of his district to establish school children's agricultural exhibits at each annual county fair. The sections of the political code relating to teachers' examinations is amended so as to include "on and after September I, I9I2, elementary agriculture." 
Pennsylvania.-The new school code provides for the appointment of an expert assistant in agriculture for the state department of education and makes agricultural education a part of the objects to be promoted by the state board of education.

Texas.-State aid to the amount of from $\$ 500$ to $\$ 2,000$ is given for one year to high schools providing approved instruction in agriculture.

Utah.-Agriculture is made a part of the course of study prepared by the state office of education for accredited high schools.

Vermont.-The state department of education has issued a Manual of Agriculture for the Public Schools of.Vermont (35).

Washington.-Elementary agriculture is made an optional subject in the eighth grade of the public schools of the state.

Wisconsin.-An act passed in I9I I makes available to each school "maintaining a department of manual training, or domestic economy or agriculture, or any or all of these departments one-half the amount actually expended for instruction in such department, not, however, to exceed $\$ 350$ for each department above named which shall have been maintained in connection with the high school and the three upper grades below the high school, but not to exceed $\$ 250$ for each department named maintained only in connection with the high school." It is possible under this act for a school district maintaining courses in these three subjects to receive $\$$ I, 050 per year from the state. No state aid may be given to any school for instruction in agriculture, domestic economy, manual training, or inclustrial branches unless the salary of every teacher giving instruction in such subjects shall receive at least $\$ 60$ per month.

The maximum state aid to any county school of agriculture and domestic economy is raised from $\$ 4,000$ per annum to $\$ 6,000-$ $\$ 8,000$ per anntm, depending upon average daily attendance. The Stont Institute located at Menomonie is to receive state support, $\$ 30,000$ for the current year and $\$ 55,000$ per annum thereafter. 


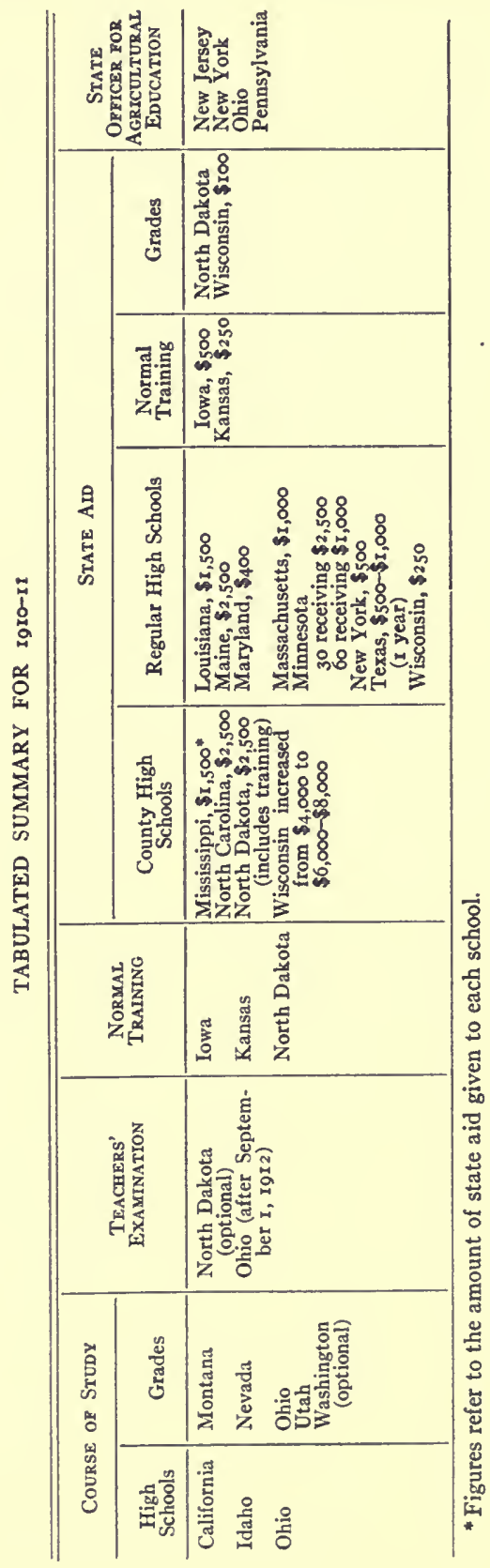




\section{CHAPTER V}

AGRICULTURAL COLLEGES, INCLUDING EXTENSION WORK, DEPARTMENTS OF AGRICULTURAL EDUCATION, AND SUMMER SCHOOLS FOR TEACHERS

Of the many agencies now promoting agricultural education in elementary and secondary schools the most important are the state agricultural colleges, for they are the "only teaching institutions that are in possession, at first hand, of the essential facts of rational agriculture." Until recently they have been too busy perfecting their own organization, and too greatly occupied in developing and promoting the scientific aspects of agriculture to give much attention to outside educational matters. It is difficult to determine just when the agricultural colleges began to take an active interest in the public schools. Dean L. H. Bailey says:

More than any other institutions they stand for democracy and nativeness of education, for their purpose is nothing less than to reach the last man on the last farm by means of the very things by which that man lives (36, p. 40).

This idea of bringing the college to the people found its first expression in various sorts of extension work dealing with the farmers directly. Now this work is well organized and is doing great service. Through farmers' institutes, farmers' conventions, farmers' excursions to the college, instruction trains, demonstration farms, and other means, the man on the farm is having the college brought to him. These efforts of the colleges are now appreciated; so much in fact, that it is often difficult for a college to meet the demands for this kind of outside instruction. But the farmer has not always had this friendly attitude. He was slow to recognize the value of what he called "book farming." Perhaps it was in these early days of agricultural extension that some of those in charge thought it worth while to give some attention to the coming generation of farmers, to the children in the public schools. 
Doubtless many individuals connected with agricultural colleges had put this idea into practice and had helped to introduce agricultural subjects in some of the public schools long before any college took official notice of this means of extension. The first college to take this matter up was the Agricultural College of Cornell University. Reference has already been made to this work under the Nixon law of $1897 .{ }^{1}$ It assumed considerable importance at once. The report of 1898 concerning this work says:

Thirty thousand teachers are enrolled on our lists and have received leaflets, and many have attended lectures explaining the methods of presenting nature-study work in the schools. Sixteen thousand children have received those leaflets which are especially adapted to their needs (24, p. I6II).

This work is administered by a department of the college known as the Nature-Study Bureau and consists of publications, correspondence, organization of boys' and girls' clubs, and lectures and demonstrations for teachers. Other agricultural colleges soon took up similar work in their respective states until now nearly all are doing more or less extension work among the public schools. At present agricultural colleges are assisting agricultural education in the elementary and secondary schools (a) by various extension methods, $(b)$ by organizing departments of agricultural education, and $(c)$ by conducting summer schools for teachers.

Extension methods vary somewhat in different states. This is probably due to differences in local conditions, state support, and policies of the colleges themselves. Usually each college develops one particular method of reaching the schools although it may use several. Several colleges follow the Cornell plan $\left(37,3^{8}\right)$ of regular publications for teachers and pupils, for example, the agricultural colleges of California (39), Kansas (40), Ohio (4I), New Hampshire (42), Rhode Island (43), and West Virginia (44). Purdue University, Indiana, and Pennsylvania State College published regularly for a while

'Chap. iii, p. 25 . 
leaflets on nature-study. Others publish occasional bulletins on various phases of public-school agriculture, for example, the agricultural colleges of Massachusetts (45, 46, 47, 48), Illinois (49), Minnesota (53), Missouri (50), Pennsylvania (51), Tennessee $\left(5^{2}\right)$, and California $(54,55)$. Material designed to aid teachers is sometimes prepared by faculty members of an agricultural college, for example, of the agricultural colleges of California ( 56$)$, Illinois ( 58$)$, and Michigan (57), to be published by the state department of education or by some school magazine.

These extension publications are distributed free of charge and often large editions have to be reprinted to meet the demand. The extension bulletin of Ohio State Agricultural College (4r), for example, is printed in editions of from 10,000 to 20,000 . The mailing-list is made up anew each year from responses to notices that names will be dropped from the mailing-list unless requests are renewed. Pupils of the public schools are expected to carry on some work suggested by the college and report upon this work in order to receive the bulletin regularly. In this way the extension department is kept in close touch with the teachers and pupils of the state. The bulletin serves several purposes: it is a means of communication between the college and the schools; it presents various phases of agriculture of interest to the pupils; it assists in organizing agricultural clubs among the public-school children; it is the organ for promoting interest in rural-school improvement, such as consolidation of rural schools and beautifying school grounds.

Each agricultural college has more or less correspondence among teachers and pupils but some colleges have encouraged it and made it a feature of their extension work. This method has the advantage that comes from establishing a sort of personal relation between the college and the individual. But the work involved in a correspondence dealing with several thousand individuals is enormous and almost impossible for an agricultural 
college, were personal answers given to each letter. A regular publication is necessary to outline and suggest work to be reported upon. The correspondence is really one-sided, for answers to individual letters may be given in the next publication or in circular letters. Only a small percentage requires personal answers. The office work is thus reduced to filing and checking reports and preparing mailing-lists. The most extensive work of this kind has been carried on by Cornell University. "Uncle John," who is supposed to read the letters, is more widely known and is more popular among the young people of New York rural communities than any other member of the university. This method is also used by the agricultural colleges of Ohio and Rhode Island. The agricultural colleges of Florida, Kansas, and Pennsylvania (59) conduct correspondence courses in agriculture for teachers.

The most successful form of agricultural extension among public-school children has been agricultural clubs $(60,6 \mathrm{I}) .^{2}$ They are now organized in nearly every state and are not only a means of imparting a knowledge of agriculture to their members, but have a wholesome reaction on the communities in which they are organized. The following is a statement of the work of boys' clubs of Louisiana:

This year, 1909, we have about 2,000 boys in our agricultural clubs. Next year we expect to have 10,000. I shall devote all of December, January, and February to the organization of these clubs in every parish in Louisiana. The corn crop in Louisiana this year exceeds in yield by 50 per cent the crop of 1908, and it is generally admitted that a large part of the increase is due to the interest created in corn during the last two years by the boys that are in the boys' clubs. The best corn show ever held in Louisiana was that of the boys' clubs at the State Fair at Shreveport the first days of this month. ${ }^{3}$

The agricultural colleges of all the southern states are active in their co-operation with the government demonstration work among boys. The most complete state organization of boys' and girls' clubs is in Nebraska (60). Here the State Agricultural

'Boys' agricultural clubs are fully discussed in chap. xii.

${ }^{3}$ From a letter of Professor V. L. Roy, Department of Agricultural Education, State Agricultural College of Louisiana. 
College and the State Department of Education work together. The organization consists of a state association, and county and local or district associations. The central or state association meets once a year and is composed of delegates from county associations.

A special course in agriculture and domestic science for boys and girls will be given at the State University Farm, beginning Monday, January I7, and ending Friday, January 2I, 1900. This course is planned for the delegates from each county of boys' and girls' agricultural and domestic science associations. Special arrangements have been made with the professors at the University College of Agriculture to give a course of instruction lasting five days..... The laboratories at the Agricultural College will be at the disposal of the delegates from the different counties during this week and professors from the college will give the instruction. The course is filled with interesting and instructive lectures and demonstrations (6o, p. II).

The agricultural colleges reach the public schools in various other ways. The extension department of Ohio State Agricultural College gives much of its attention to rural schools. The superintendent of agricultural extension in this institution believes that the most important work of his department lies in improving the rural schools, not only by helping to introduce agriculture, but by interesting the patrons in consolidating small district schools, in making other improvements, and by encouraging the teachers to adjust their school work to fit the needs of the communities in which they live. The Mississippi State Agricultural College gives a short course of one week each winter in the county agricultural high school. Many colleges send representatives to address teachers' institutes and other teachers' meetings. They also furnish judges for boys' corn shows, and corn and stock-judging contests.

The early extension work of agricultural colleges among the public schools was intended to awaken an interest in agricultural affairs. It was mainly propaganda for arousing a favorable sentiment toward the subject. The more recent work has had for its aim the actual introduction of certain phases of agriculture into the schools, and to render assistance to teachers who wish 
to teach the subject. The demand on many colleges for this kind of work has become too great to be properly met by the regular extension departments. To meet this situation special departments are being organized. These are usually known as departments of agricultural education. The following tabulation shows the organization of these departments up to date:

\begin{tabular}{|c|c|c|c|}
\hline State & Year & State & Year \\
\hline Alabama........... & 1909 & Missouri. & 1909 \\
\hline California............ & 1909 & Nebraska... & 1909 \\
\hline Georgia............ & IgI I & North Carolina.. & I909 \\
\hline Idaho............. & 1909 & Ohio $\ldots \ldots \ldots \ldots$ & 1910 \\
\hline Illinois.... & I905 & Oklahoma. & 1909 \\
\hline & r9o9 & Oregon.... & 1909 \\
\hline Indiana........... & 1908 & Pennsylvania. & 1909 \\
\hline Iowa...$\ldots \ldots \ldots \ldots$ & IoII & Rhode Island. & Igri \\
\hline Louisiana............ & 1909 & Utah............... & I911 \\
\hline 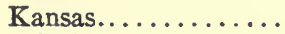 & IgII & Washington.......... & IgII \\
\hline Michigan............ & 1908 & West Virginia........ & IOII \\
\hline Massachusetts....... & 1907 & Wisconsin........... & Igog \\
\hline Mississippi ........ . & I9II & & \\
\hline
\end{tabular}

The agricultural colleges of Arkansas, Delaware, Maine, Massachusetts, North Dakota, Oregon, Pennsylvania, South Dakota, Vermont, Washington, and Wisconsin give courses in education to their students who expect to become teachers. The Agricultural College of Tennessee added a department of agricultural education temporarily in 1908 for one year and expects to re-establish it. A number of other colleges have signified their intention to establish departments of agricultural education as soon as practicable.

It will be seen from the above summary that most of these new departments began their work in 1908 and 1909. This is probably due, at least in part, to a provision of the Nelson amendment of $1908(26,36$, p. 5) whereby "said colleges may use a portion of this money (referring to additional appropriation) for providing courses for special preparation of instructors for teaching the elements of agriculture and mechanic arts."

Massachusetts in 1907 made a special appropriation of $\$ 5,000$ for this work $(36$, p. $4 \mathrm{I})$. In addition to the regular instruction 
given during the school year and summer school for teachers, the department conducted, in 1908, I909, and I9I0, conferences on agricultural education (46). At the conference of 1909, a committee appointed in 1908 made a report outlining a series of exercises "of experimental character that should serve as material for the teaching of agriculture in the common schools" (45). The department has extended its work to include courses of instruction during the college year to undergraduates expecting to teach; lectures before teachers' and farmers' meetings; summerschool instruction to teachers of elementary agriculture and school gardening; co-operative work with the North Adams State Normal School; organizing boys' and girls' agricultural clubs; conducting school gardens on college campus for the school children of Amherst.

The departments of agricultural education in other colleges are just getting under way, and it is therefore not possible at this time to give any report of their work beyond a few brief statements. Boys' clubs and teachers' institutes are receiving special attention in several states. In Missouri the schools of the county in which the University of Missouri is located are taking up the study of agriculture under the direction of the professor of agricultural education who visits the schools with the county superintendent, gives instruction in the seventh and eighth grades and makes suggestions to the teachers for carrying on the work. In I9IO-I I work in thirteen of these "demonstration schools" was conducted, and about fifty others were reached by correspondence. The University of Illinois is pursuing a similar plan. In Indiana the department was established especially to enable the students of Purdue University to comply with the state law requiring teachers in the public schools to have some professional training. In the University of California the department of agricultural education is especially well organized, covering the following lines of work: instruction to teachers during the regular and summer sessions; publication of circulars on school gardening, tree-growing, high-school agriculture, elementary 
agriculture, etc.; organizing and conducting school garden work in city and rural schools; conducting seed exchange with schools interested in tree-growing and gardening; conducting organizations for the encouragement of nature-study; visiting, supervising, and teaching in the public schools; assisting at teachers' meetings; organizing excursions of teachers to university stations; organizing boys' and girls' clubs and publishing a paper to unify this work; assisting with the demonstration train; correspondence with superintendents, principals, and teachers, and others interested in educational work. Various specialists of Kansas Agricultural College, under the direction of the department of agricultural education, have prepared a series of six agricultural primers. These have been placed in the hands of each teacher of the state, and have been used as a text in all the normal institutes during the summer of I9I. In general, these new departments seem to regard the development of agriculture in high schools as an important part of their work. Mention should be made in this connection of the co-operation of the College of Agriculture of Cornell University and Teachers College of Columbia University for the training of students for special work as teachers of agriculture in high schools and normal schools. "Appropriate courses in agriculture are taken at Cornell University and the study of educational problems at Teachers College" (36, pp. 36-37). The Pennsylvania Agricultural College offers a special course of one year for graduates of normal schools and colleges who expect to teach in the public schools. The department of agricultural education is also giving instruction by correspondence to a large number of teachers. The University of Wisconsin is making special effort to prepare teachers for work in secondary agriculture in the public schools. One course of study leads to the B.S. degree in agriculture, and to a university teachers' certificate which requires a certain amount of work to be done in education; a second leads to the degree of A.B. with a minor in agriculture; a third leads to the degree of A.B. with a major in manual arts and a minor in 
agriculture; a fourth leads to the degree of B.S. in the college of agriculture with a minor in manual arts or physical or biological science.

The number of agricultural colleges giving summer courses for the benefit of teachers is increasing rapidly. During the year I9I I courses were given in the agricultural colleges of the following states: Alabama, California, Connecticut, Georgia, Illinois, Kansas, Massachusetts, Minnesota, Mississippi, Missouri, New Jersey, New York, North Carolina, North Dakota, Ohio, Oklahoma, Oregon, Pennsylvania, Rhode Island, Tennessee, Utah, Vermont, Washington, West Virginia, Wisconsin, Wyoming, and perhaps others. These courses last from three to eight weeks and are well attended. The indications are that the attendance and interest will increase and that summer schools of agricultural colleges will become a considerable factor in elementary and secondary agricultural education. 


\section{CHAPTER VI}

\section{STATE NORMAL SCHOOLS}

It is the business of state normal schools not only to train teachers but also, as far as conditions permit, to find out by experiment in practice schools, what to teach and how to teach it. When both aspects of the work of these schools are considered, the important relation which they bear to agricultural education, particularly in elementary schools, becomes apparent. The problem of the normal school in this matter is twofold: $(a)$ to meet the rapidly growing demand for teachers who are able to give satisfactory instruction in elementary agriculture, and $(b)$ to reduce the subject to a proper pedagogical basis, in other words, to determine what phases of this great subject may be undertaken in the elementary schools under average school conditions both from the standpoint of the child and of the teacher.

The following is a brief summary of the efforts of the state normal schools to find a solution of this twofold problem. The data have been gathered from one hundred and thirty-seven of the one hundred and forty-five schools now actively engaged in training teachers. ${ }^{1}$

When the diverse social, educational, and industrial interests of the country as a whole are considered it is to be expected that these differences will be reflected in the types of instruction given in the various normal schools. To these differences brought about by conditions more or less local are to be added those due to tradition. The older schools are usually less elastic and adaptable than the newer ones. Bailey regards the latter fact as a very serious obstacle in the way of a general introduction of agriculture into these schools. He says, "One cannot look to all the existing normal schools in the older states, or even to any

${ }^{2}$ In 19ro the nine state normal schools of Oregon were closed, owing to lack of financial support from the state. 
considerable part of them, for the training of teachers for this kind of work" (36). This statement must be qualified for there are many exceptions. For example, the Johnson State Normal School of Vermont has been offering courses in agriculture for over eight years, while the one at Laramie, Wyoming, recently established, does not give courses in agriculture but prepares its graduates to teach in cities.

The number of graduates of state normal schools that teach in agricultural communities varies exceedingly not only in different states but among the schools of a single state. Reports from seventy-six show that twenty-eight have from 60 to roo per cent of their graduates going into schools of rural communities; twenty-seven have from 20 to 50 per cent; and twenty-one have from I to Io per cent. Of the twenty-eight having from 60 to roo per cent of their graduates teaching in rural communities, twenty are offering instruction in agriculture and fifteen require it; of those having from 20 to 50 per cent, twenty offer instruction in agriculture and nine require it; of those having from I to Io per cent, eleven offer agriculture and three require it. If this proportion should apply to all the schools it would seem to indicate that the number of graduates of normal schools going into agricultural communities is quite large, perhaps larger than generally supposed. It indicates also a tendency of the schools to adapt their work, at least to the extent of introducing agriculture, to the needs of the communities where their graduates teach. This estimate is only approximate and only inferences may be drawn from it. It does not take into consideration the large number of students who take a portion of the course and who for the most part go into the country to teach. One normal-school president says: "There are very few of our graduates who teach in rural schools, but there are multitudes of our undergraduates who do so." This statement suggests another phase of the problem of normal-school instruction which has received little or no attention, viz., what recognition in the course of study or character of instruction should be given to the 
fact that so many who attend the normal school for part of the course drop out and become teachers in rural schools? For example, in the school just referred to, the instruction is evidently adjusted to meet the needs of students who expect to teach in city schools. No agriculture is taught although "multitudes of the undergraduates" become teachers in rural schools, and in the state itself agriculture is the chief industry.

The development of agricultural instruction in state normal schools has on the whole kept pace with the growth of the general interest in the subject. It is hard to say just when this subject was first taken up. Probably the first institution to begin this work under the name of agriculture was the Rock Hill State Normal School of South Carolina, which offered courses in agriculture as early as I895. The Johnson State Normal School of Vermont offered its first course in agriculture in I9OI, and about this time the subject was introduced in some of the state normal schools of the Middle West (62).

In 1906 a report on "Preparation of Teachers to Give Instruction in Elementary Agriculture" was prepared for the Joint Board of the California State Normal Schools trustees (63). This report showed that the normal schools of Minnesota, North Dakota, Nebraska, Missouri, and South Carolina were attempting to prepare teachers to give instruction in elementary agriculture; that some attention was being given to the subject in the normal schools of Illinois, Utah, and Oklahoma; that nothing was being done to furnish such training in the schools of Iowa, Kansas, Michigan, Ohio, Pennsylvania, Alabama, North Carolina, or New York, but that several of these schools were, however, getting ready to undertake the work as soon as possible.

In a study of ninety-one state normal schools reported to the National Education Association in 1907, it was shown that seventy-five believed in an instruction in agriculture, and were either giving it in some form or desired to do so. Sixty-one of this number were either offering courses or had made plans for such courses for the following year. Seven of these were giving 
only a little agriculture in connection with other science courses. Eight were doing still more in connection with school gardens and were planning to extend the work. The remaining fortysix were giving definite courses in agriculture (64).

During 1909-10 of one hundred and thirty-seven state normal schools, eighty-seven were giving some instruction in agriculture. In fifty-two of those offering courses, twenty-two made it elective and thirty required it. Of those not giving instruction in agriculture, thirty-seven gave it incidentally in connection with botany, nature-study, or some other course in science, and nearly all those giving courses in agriculture also gave some attention to the subject in other science work, particularly in botany and nature-study.

It will be seen from the above that normal schools are rapidly introducing agriculture. The number of schools offering such courses has increased from about 20 per cent in 1906 to more than 50 per cent in 1909. Indeed, the demand for well-qualified instructors in agriculture for normal schools exceeds the supply. One normal-school president says that he tried for over one year to secure a competent instructor. Davenport says: "The call is sharp from the normal schools of the Middle West which have this year (1909) taken some of the best trained and most promising teachers of this class" $(65, \mathrm{p}$. I 44). The call is not alone from the Middle West but the East as well. During the present school year one of the normal schools of the Atlantic Coast states secured a teacher who, at the time of his appointment, was professor of agricultural education in an agricultural college of the Middle West.

Letters from presidents and others connected with normal schools not now (I9I0) offering agricultural instruction indicate that in many of these schools plans are under way to introduce the subject as soon as possible. Included in this number are the normal schools of New York and Pennsylvania, none of which now (I9IO) offers such instruction except incidentally with nature-study and other subjects. 
The character of the work in agriculture varies much in different schools. But there is one feature of the instruction that is common to all, viz., evidence of the newness of the subject and of the fact that it is in an experimental stage. In some schools the work in agriculture is only in name, much better instruction being given in other schools in courses in nature-study.

The time given in the course of study varies from ten weeks to two full years, the average being less than one year. One interesting reaction following the demands for agricultural instruction is to be found in the readjustment in science courses, especially in the biological sciences. The title agricultural botany and agricultural zoölogy frequently occurs in courses of study. One fails to find in some of these, however, justification for the new titles, for the instruction remains much the same, with emphasis on morphology. The attitude of certain teachers of biology toward their subject is well illustrated by the following extract of a letter received from a member of the faculty of a large state normal school. "I obtained over one dozen kinds of water animals one day from a pool when the science (biology) teacher said he saw none in it. He was sending to New York City for crayfish when a brook near the building was full of them. The boys (in training school) had made nets and would have been glad to have caught the animals for him." Perhaps the influence of such a teacher was partly responsible for the ignorance of a practice teacher (a senior) who stood in a bed of marigolds and asked if there were any marigolds in the garden. The introduction of agriculture will no doubt have much to do in changing this attitude.

It will in the end exert a profound influence upon the teaching of general science. There is no manner of doubt that the masses of people are best benefited by the teaching of science in its applied form.... Agriculture is evidently to be the pioneer in this business of the adaptation of science to the common affairs of life in the schools that are attended by the masses, and if this is true its incidental service may be even greater than its direct. In the meantime it is vastly significant that the schools 
where teachers are made have at last commenced to study real life in one of its most concrete forms $(65$, pp. 45-46).

Normal schools have so far been too much occupied in providing for instruction in agriculture to give much attention to the pedagogical problems of the subject. These problems concern $(a)$ the organization of courses in the normal school itself, and $(b)$ methods of teaching the subject in the public schools. Naturally, the former has been the first to receive attention. The organization of work in agriculture has been in two directions, one in the science work already referred to, and the other in the purely agricultural courses recently introduced.

Special efforts of adjustment have affected nature-study more than other science studies. Many believe that as far as the elementary schools are concerned agriculture should have the naturestudy aspect, or as some prefer to say, nature-study should have an agricultural trend; that since nature-study has to do with material drawn from the child's immediate environment, and since a large part of this environment is more or less agricultural (consisting of animals and plants under control of man) a good course in nature-study forms an adequate preparation for a teacher to give such agricultural instruction as will meet the needs of rural schools, and at the same time enables a teacher to make use of school gardening and other practical or economic phases of the subject in city schools (66).

The particular direction in which nature-study has been most modified in its readjustment has been in the school garden $(67)$. It has been found that the school garden may serve as a very effectual means of unifying most all nature-study work. Children are not only able to "grow things" in gardens, but in doing this work successfully have had to solve many of the problems that are fundamental to agriculture. The character of the soil, the conservation of water by cultivation, the protection of plants from insect and other enemies, and many other factors of successful plant-growing are encountered. Many normal schools have regarded this readjustment of nature-study and other sci- 
ence work as sufficient to meet the demands for agricultural instruction in the training of elementary teachers, and are working with this end in view. Some of the normal schools of California, Illinois, Massachusetts, New Jersey, and other states, and many of those schools now offering courses in agriculture, have made substantial progress in the readjustment of science work.

Instruction in agriculture as a separate subject in normal schools is now in an experimental stage. Yet certain work and methods seem to have proved successful. The first publication of work adapted to normal schools was in the form of a textbook based on teaching experience in the Kirksville (Mo.) State Normal School ( I 76). Recently a very concrete treatment of the problem has appeared as a government publication. It is an account of what is actually being done and how it is done in a typical normal school. The writer says in his introduction,

The aim of the normal school is to prepare young men and women to teach in the elementary schools of the state. The young people who attend come from farms or smaller towns, and when they go out to teach they are called upon to give instruction in what is known as elementary agriculture. To meet this demand, a department of agriculture was established four years ago. The course at first extended through one term's work but has been lengthened until practically two full years are now devoted to agricultural instruction. The work has attracted many young people, and the success with which they have subsequently instructed others along these lines indicate that the instruction has been effective. Not all the problems in teaching agriculture have been solved but it may justly be claimed that a few of the more difficult of them have been solved (68).

Other similar publications of successful practice which have been tested by the work of students who have become teachers will contribute much toward the pedagogical efficiency of the subject.

From the standpoint of methods of teaching the subject in the public school, little has been done. A very promising beginning of the study of this question was made at the Peru (Neb.) State Normal School in February, 1909, when the Normal Agricultural Society was organized. The purpose of this society is to aid teachers in "handling the new subject of agriculture in 
public schools of the state." Those interested in its organization have expressed the hope that "it will become a pedagogical laboratory for testing and discovering methods to improve and extend the teaching of agriculture throughout the schools of Nebraska." The director is the head of the department of agriculture in the Peru Normal School and conducts for the society a column in the Nebraska Farmer which is to be the official publication of the society (69).

An interesting experiment limited to one phase of agriculture is now being conducted at the Western Illinois State Normal School at Macomb in co-operation with the Illinois State Agricultural Experiment Station. A soil experiment field of two and one-half acres has been provided by the normal school. The school

as its share of the responsibility, takes full charge of the field operations implied in the plans. Such co-operation provides for both scientific and educative values in the work and it is proposed to make the results as far reaching as possible. Not alone to teachers and prospective teachers will it be valuable but as well to persons now engaged in agricultural practice (70).

A few helps to teachers have been worked out in normal schools and published, for example, from Cape Girardeau, Mo. (7I), Los Angeles, Cal. (72), Greeley, Colo. (73), Hays, Kan. (74), and Chico, Cal. (75). They consist of discussion of agricultural subjects suitable for public schools, and methods of instruction.

There is one large class of normal-school students already mentioned that is not adequately provided for. This class is made up of students who wish to teach in rural schools and who can spend only a year or part of a year in preparation, and is the largest in states where emphasis is placed on examination for certification. These students attend primarily to prepare for examinations.

It has been the custom in most schools to provide for these students by offering short review courses. Often instruction in elementary agriculture and sometimes in manual training forms 
a part of this work, and is really the only part that takes into consideration the life of the community in which these students are to teach. These short courses are generally regarded by normal-school teachers as unsatisfactory, both on account of the shortness of the time given and the irregular preparation of the students themselves. Although the situation is recognized as a difficult one very little has been done to improve it. There are several schools, however, that have undertaken to give their students of this class some real preparation for this work as teachers. Some have arranged with local public-school authorities for a one-room rural school to be used as an observation or practice school. Others have built or have control of a one-room schoolhouse and have endeavored to make it a model of its kind so as to show concretely the possibilities of a rural school. For example, the Kirksville (Mo.) State Normal School has a wellappointed single-room schoolhouse. It has been

designed and constructed to show that a rural school anywhere can have all the conveniences and comforts offered in any city building. The children are transported in covered vehicles to and from school. It is a model school so far as it can possibly be made such. It is to exemplify the best things which a school board and a good teacher with up-to-date facilities can do in and for a rural school.

Special provision is made for instruction in manual training, elementary agriculture, and home economics. ${ }^{2}$

Two somewhat similar plans for rural education should be mentioned in this connection. Both of these have the larger possibilities of teaching in rural communities in view. One is a course of two years called "rural arts" given by the Harrisburg (Va.) Normal and Industrial School for Women. The course requires high-school graduation for admission. The object is to

give its students a training of mind, heart, and hand which will fit them for efficient service in rural schools, and for intelligent and appreciative participation in the life of rural communities. It will not attempt to train farmers; it cannot be expected to turn out agricultural experts. Its work

'Bulletin First District Normal School, Kirksville, Mo., IX, No. I (1909), 9-I6. 
will be limited to those phases of farm life in which women usually, or frequently, or may properly participate, and to that portion of agricultural instruction which may properly be given by female teachers in elementary and high schools.

The course includes besides some of the regular normal courses, horticulture, elementary agriculture, rural sociology, poultryraising and bee culture, dairying, forestry and floriculture, and theory and practice in rural arts. ${ }^{3}$ The other is a course of two years known as "rural industrial education" given by the Ohio State Normal College of Miami University. Its requirements for admission are the same as for other college courses. This course is expected to meet the needs of township superintendents, principals, and science teachers of high schools in rural communities, and to enable these teachers to adapt the work of their high schools more nearly to the life of the school communities. The course includes education, school administration, rural sociology, agriculture (two years), forestry, botany, manual training, rural education, methods of rural-school organization, physical geography, entomology, and physics of farm machinery. In planning this course, which is at present a tentative one, the influence of the high school of an agricultural community on the elementary schools was carefully considered. Most of the teachers in the elementary schools of these communities are graduates of these high schools. They seldom receive further training. Therefore, with a high school organized to meet the needs of the community, its influence should thus extend to the elementary schools through its graduates who become teachers (76).

Any account of the work of the state normal schools in agricultural education would be incomplete without some special reference to the teachers themselves who are engaged in this work. Many are doing their work under considerable disadvantage. This applies not only to the fact that agriculture is a new normal-school subject to be adapted to new conditions but

'Bulletin State Normal and Industrial School, Harrisburg, Va., I, No. I (1909), 88-92. 
also to the fact that it has been added as an additional subject to a teacher's already overcrowded program. One teacher writes that he is offering agriculture this year for the first time, but is expected also to teach physics, chemistry, botany, zoölogy, physiology, geology, and physical geography. Several teachers have bought small farms primarily in order that their students might have the advantage of actual field experimentation.

With the earnest body of teachers now beginning to take up the work and with the progress already made it seems likely that the demands for agricultural instruction in the training of teachers in state normal schools will soon be met. The real test of the value of this training is in the work of the teacher who goes out from the schools and it is now too early to pass judgment. 


\section{CHAPTER VII}

\section{NATIONAL EDUCATION ASSOCIATION-STATE AND OTHER TEACHERS' ASSOCIATIONS}

It is said of the National Education Association that it "lias been, and is now the body-guard of public-school instruction in our country." While this statement may not be taken literally, the fact remains that this Association is the one educational organization which is truly national in character, embracing as it does the interests of all parts of the country and all phases of education.

It was organized in Philadelphia on August 26, I 857, under the name of the National Teachers' Association by a group of teachers who met in response to a call sent out the previous year to all the local teachers' associations. The call itself is significant, for it expresses the spirit which has, on the whole, been manifest during the entire existence of the Association: to teachers of the United States "who are willing to unite in a general effort to promote the general welfare of our country by concentrating the wisdom and power of numerous minds, and by distributing among all the accumulated experiences of all" (77).

The name was changed in 1870 to the National Educational Association and in 1907 to the one it now bears. As it was founded to meet the demands of a natural growth, it has never departed from the essential principles on which it was founded. The extent to which the "accumulated experiences of all" have been "distributed among all" may be seen by a reference to the published list of titles of papers and discussions from 1857 to 1907. This list covers over seventy pages and embraces almost every imaginable subject of educational interest (78). Many discussions are of only passing importance; some are but means of exploiting favorite theories; others are real contributions to educational thought. 
Beyond the propaganda which is expected of any large educational body the most valuable work of the Association has been through its committees which have been appointed from time to time to investigate and report upon various important questions of general interest.

The Association being a sort of clearing-house for educational ideas, its published Proceedings provide a valuable source of information concerning all kinds of tendencies and movements in education. Agricultural education has received a share of attention proportional to the different stages of its development. The interest of the Association in this subject as reflected in the Proceedings extends over four periods: the first from 1857 to 1897 , the second from 1897 to 1903 , the third from 1903 to 1906 , and the fourth from I906 to the present time.

Agriculture was not considered as a separate subject except as referring to agricultural colleges until the latter part of the first period. Industrial education, however, was discussed as early as I866. In I875 a Department of Industrial Education was formed. At this meeting the question: "Can Elements of Industrial Education Be Introduced into Our Common Schools?" was discussed in a paper by John D. Philbrook. He said: "Science and art with reference to their special application to industrial pursuits must be included in the modern school course." Drawing, geometry, natural history, physics, and chemistry were mentioned as the branches which lie at the foundation of industrial education.

At the meeting of the following year (1876) William $\mathrm{T}$. Harris in his report as chairman of the committee on "Course of Study from Primary School to University" refers to the difficulty of deciding "the amount of prominence to be given to industrial branches in comparison with those chiefly productive of theoretical culture." He says also: "The primary school has been called upon to fit for life." In the course of study reported by the committee for the district schools, topics relating to nature 
are suggested as follows: "Inorganic-arithmetic, oral lessons in natural philosophy; organic-geography, oral lessons in natural history."

These two references to the early discussions of industrial education are given to show that the need of such instruction was being considered at this time, and from a somewhat general viewpoint which might include agriculture although it was not specifically mentioned. The Department of Industrial Education, however, gave its attention almost wholly to urban conditions. Drawing and manual training held prominent places in the discussions of all the meetings. In 1890 the name of the Department was very properly changed to Industrial and Manual Training, and in 1899 to Manual Training.

In 1893, at the International Congress of Education held under the auspices of the Association, agriculture had a place on the program (79) but the paper was read by a Russian. Perhaps his account of the use of agriculture in the rural schools as a school subject had something to do with directing the attention of the Association to the rural-school problem. At any rate, at the meeting of 1895 a committee of twelve was appointed to investigate and report upon rural schools as to maintenance, supervision, supply of teachers, and instruction and discipline.

The report was submitted to the meeting of 1897 . It contains a number of suggestions which involve more or less agricultural instruction such as surface features of the earth including soils, weather, plant and animal life, etc. It also emphasizes the need of a course of study "framed with direct reference to actual conditions that prevail in country life and in large measure determine it. Among the most important points to be kept in mind are the following: (I) There is a general lack of appreciation of immediate surroundings; (2) there is an almost total lack of scientific skill in farm work; (3) in the country there is a great dearth of social life." Under (2) certain phases of mechanics, manual training, biology, meteorology and physics 
of the atmosphere, mineralogy, and chemistry were included. Another portion of the report is devoted to the "farm as the center of interest," and a great many things which we now find in all textbooks on elementary agriculture are mentioned (80).

During the latter part of the second period (I897-I903) agriculture appeared as a topic for discussion at nearly every meeting. At the meeting of 1902 five papers were read as follows: "The Value of a Large Agricultural School in Indian Service"; "Correlation of Schoolroom and Farm Work"; "The Education of the American Farmer"; "The Practical Value of Teaching Agriculture in the Public Schools"; "The Teaching of Agriculture with Reference to Future Employment."

In I903 a committee on "Industrial Education in Schools for Rural Communities" was appointed. The committee made its report at the meeting of 1905 and represents the most important contribution of the Association to agricultural education in the third period (1903-6). A considerable part of the report deals with agricultural subjects and their adaptation to elementary and secondary rural schools. Among the recommendations of the committee are the following: "A modification of the course of study should be made for the introduction of work, especially in the elements of agriculture and domestic science, and such further lines of industrial education as local conditions make feasible. ... The establishment of schools distinctly industrial (agricultural high schools) in their character is absolutely necessary for the proper development and organization of the rural-school system."

A detailed course of study for all the grades is submitted. It is an interesting contrast to the course of study reported by the Committee of Twelve of 1897 . In the latter the idea that agricultural subjects should receive attention in the rural schools is suggested rather than definitely stated and outlined. In the former this idea is expressed in a definite and concrete outline with illustrative lessons.

The work in agriculture for the secondary schools is particu- 
larly well outlined, and illustrated by accounts of work actually carried on in two existing agricultural high schools: one the Dunn County (Wisconsin) School of Agriculture and Domestic Economy; the other, the Minnesota Agricultural High School connected with the Agricultural College of Minnesota (8I).

The fourth period is characterized by a more active interest in agricultural education. Three important steps were taken: (a) continuation of Committee on Industrial Education in Schools for Rural Communities; $(b)$ formation of National Committee on Agricultural Education; $(c)$ organization of a Department of Rural and Agricultural Education.

The Committee on Industrial Education in Schools for Rural Communities made two reports, one at the meeting of the Association in 1907 and the other at the meeting of 1908.

In some preliminary investigation for the supplementary report the correspondence showed that "what was most wanted was a definite statement of what was actually being done in different parts of the country in providing facilities for industrial education in rural communities." The supplementary report represents the efforts of the committee to satisfy this demand. It consists of three parts: a discussion of the general problem, including school buildings, school gardens, manual training, nationalizing the work (referring to the Davis bill then before Congress) and in what schools agriculture should be taught; industrial work in New England, New Jersey, Pennsylvania, and New York; experiences and opinions of individual teachers in the preceding territory (82).

The second report (I908) is limited to "a presentation of what is being done in schools representing four types of organization, as showing the possibilities in other schools of these types and the conditions under which these possibilities may become actualities." The schools selected and reported upon are the Waterford High School, at Waterford, Pa., the Cecil County High School, at Calvert, Md., the John Swaney Consolidated School, in Magnolia Township, Putnam County, Ill., and the 
congressional district agricultural schools located at Americus and Monroe, Ga. Each type is described in sufficient detail to give a clear understanding of its organization and actual work.

The final conclusions of the Committee are summed up in nine paragraphs, two of which should be quoted here since they refer to conditions that continue to exist:

That the supply of properly trained teachers for carrying on this work is totally inadequate to meet even the present demand, and that the increase in the demand for such teachers in the near future requires a very large increase in the facilities for their preparation, and to supply these facilities special training schools should be established throughout the country for the preparation of elementary rural-school teachers; that the normal schools whose graduates find positions in rural schools should broaden and strengthen in every way their courses of instruction along industrial lines adapted to the needs of rural schools; that the agricultural colleges favorably situated for such work should undertake to organize special courses for the purpose of training teachers for the secondary schools, capable of giving instruction in agriculture and related subjects.

That in the growth of public sentiment, in the development of ideals, in the preparation of courses of study, and in the facilities for the training of teachers for industrial work in rural schools, decided progress has been made in recent years; but that much yet remains to be done before the importance and value of this kind of industrial education shall be fully appreciated by all concerned, and before it shall receive its appropriate recognition and find its proper place in our educational system $\left(8_{3}\right)$.

In 1906 a call was sent out to members of the Association who were interested in agricultural education to be present at the annual meeting of the Department of Superintendence for the purpose of discussing various problems concerning this subject. There was an encouraging response and an interesting meeting was held. At this meeting the National Committee on Agricultural Education was formed.

The second conference of this committee was held at the meeting of the Association of 1907. At this session three important papers were read and discussed: "The Work of the National Government in Extending Agricultural Education through the Public Schools"; "What Has Been Done and Is Being Done by 
Normal Schools and Agricultural Schools for Popular Education in Agriculture" (84); "The Work in Agriculture as Conducted by State and County Organizations of Young People in Club Contests." The third conference of the committee was held at the meeting of the Department of Superintendence held at Washington in 1908. Just at this time the Davis bill (28) and the Burkett bill (28) were being considered as separate measures. Under the direction of the National Committee on Agricultural Education a conference was held with all parties interested in the two measures, resulting in the introduction in Congress of a new bill embodying the essential features of the two separate ones. A subcommittee conferred with the President of the United States, and also with the Senate Committee on Agriculture in behalf of national aid for agricultural instruction.

The fourth, fifth, and sixth conferences of the committee were held at the meetings of the Department of Superintendence of I909, I9I0, and I9II. At the fourth session two committees were appointed, and reports were made at the fifth session. These were on "Credit Value of High-School Agriculture for College Entrance" and "The Course of Study in Agriculture -What Shall It Be?" Considerable attention was given at each of these meetings to federal aid measures (Davis bill, Dolliver bill, Page bill) before Congress.

At the nineteenth annual convention (1905) of the Association of American Agricultural Colleges and Experiment Stations, K. L. Butterfield introduced the following resolution:

Whereas, This Association believes that the questions involved in the general and technical education of the rural people are of sufficient importance to warrant special recognition in the great gatherings of American educators: Therefore, be it

Resolved, That our executive committee be hereby instructed to take such steps as it may consider necessary in an endeavor to secure the consent of the National Education Association to add to its list of special departments a department or departments of rural and agricultural education (85, p. 28).

This resolution was adopted by the Association and D. J. Crosby was delegated to bring the matter before the National 
Education Association (85, p. 47). As there was no meeting of this Association in 1906, the application was deferred until the Los Angeles meeting of 1907, when on July 8, Mr. Crosby presented the following:

In view of the widespread and active interest in the improvement of rural schools and in the development and extension of instruction in agriculture and the allied subjects of nature-study and school gardening in the colleges and public schools of the country, and in view of the fact that there is no national organization of teachers for discussion of rational methods of instruction in these subjects, the undersigned active members of the National Education Association respectfully request permission to form a Department of Rural and Agricultural Education co-ordinate with the other regularly constituted departments of this Association (followed by signatures of twenty-eight active members).

This petition was received and authority was granted to form such a department (82, pp. 44-45). The department was organized at the Los Angeles meeting, but owing to some irregularity in the proceedings it was not officially recognized. The official organization of the department took place at Washington, D.C., February 27, 1908, during the 1908 meeting of the Department of Superintendence (83, p. I36).

Four regular meetings of the Department of Rural and Agricultural Education have been held (in 1908, 1909, 1910, and I9II). As they are fully reported in the Proceedings of the Association no further reference need be made here, except to state that they were well attended and much interest was shown in the discussions.

It will be seen from the foregoing account that the National Education Association has been and is an important factor in agricultural education, first in the way of propaganda, by bringing the subject prominently before the teachers of the entire country, and second by real constructive work through its committees and its Department of Rural and Agricultural Education.

Through the published Proceedings of the Association the development of the movement for agricultural education can be followed as in no other educational literature excepting that of 
the National Government through its publications of the Department of Agriculture and of the Bureau of Education.

\section{STATE AND INTERSTATE TEACHERS' ASSOCIATIONS}

There are about seventy of these associations. Some were in existence long before the organization of the National Teachers' Association. Most of them publish proceedings of their meetings, but for lack of funds and other causes accounts of these meetings are not always published except in local papers. Enough of these proceedings, however, are available in published form to trace any educational movement as reflected by the discussions of these meetings. One finds that agricultural education began to receive attention from these associations about the same time that the National Education Association became actively interested in it. We find, for example, the Alabama Educational Association in 1905 devoting a considerable part of its program to the subject, and calling W. M. Hays to give an address; the California State Teachers' Association in 1905 holding joint sessions with the State Farmers' Institute, and calling L. D. Harvey and A. C. True to make addresses; the Georgia Teachers' Association in its meetings of 1903, 1906, 1907, and 1908 giving prominence to the subject, in 1908 holding a conference with representative business men from forty-four of the fifty counties of the state concerning the district agricultural high schools. These illustrations are typical of the consideration given agricultural education by most of these associations at their recent meetings. Their contribution consists chiefly in creating an interest in the subject. Sometimes, however, movements are started that result in state legislation.

It is not possible in the limits of this chapter to enter into further discussion of the work of these associations, instructive as it might be to follow carefully the development of agricultural education as expressed by these bodies of teachers in various sections of the country. 


\section{CHAPTER VIII}

\section{EDUCATIONAL PERIODICALS}

The number of educational periodicals published in the United States probably exceeds that on any other subject. Most of these publications are in the library of the United States Bureau of Education. In I906 they numbered one hundred and fifty-six (86).

For purposes of classification the periodicals included in this number may be considered fairly representative of all such publications in the United States. They naturally fall into three groups: (I) general, including those devoted to subjects of general interest or to various general problems in education, and whose circulation is not limited to any particular section of the country or class of readers; (2) special, including those devoted to some single phase of education, as, for example, orthography, penmanship, phonetics, geography, school art, manual training, science, etc.; (3) local, including those whose main circulation is confined to a single state or group of states.

The bibliography alone of contributions and references to agricultural education in these periodicals would occupy several times the space allotted to a single chapter of this book. It will therefore be necessary to confine the discussion of this subject, as represented in various educational periodicals, to some references of historical interest in Barnard's Journal of Education, and to a brief account of each of the above three groups.

No investigation of an educational movement would be complete without consulting Barnard's Journal of Education. "Wherever libraries of education are now gathered his encyclopedic journal has a place of honor. Whoever will found such a library must look first to secure a set of this great work. Because he saw so far, the contents of that great work will not soon grow out of date" $(87)$. In this work are many references to agri- 
cultural education. Three are worthy of special interest: early agricultural schools; agriculture in schools for homeless children and in schools for delinquent children; and agricultural education in foreign countries.

An account is given of probably the first agricultural school in the United States. It was founded in 1797 at Lethe, S.C., by Dr. John de la Howe. He left a will which provided for the endowment of "an agricultural or farm school in conformity, as near as can be, to a plan proposed in the Columbian Magazine for the month of April, I787, for educating, boarding, and clothing twelve poor boys and twelve poor girls of the Abbeville District." The endowment consisted of 500 acres of farm land and $\mathrm{x}, 000$ acres of forest (88).

An account of another early school is of interest because it anticipated some of the present notions of industrial education. The following is a quotation from a letter of a Mr. Coe to the son of Josiah Holbrook, the founder of the school:

He [Josiah Holbrook] had long cherished the idea of endeavoring to found an institution in which the course of instruction should be plain and practical; an agricultural school, where the science of chemistry and mechanics and land surveying should be thoroughly drilled into the minds of the pupils by practice. With these views the agricultural seminary was commenced in Derby (Conn.) in 1824, and continued to the fall of 1825 , under the direction of your father and myself; and, as far as I know, was the first educational movement of the kind in all that region.....We did what we could to train the students in the analysis of soils and in the application of the mechanical powers to all farming operations, and took out our young men often into the field and country for practical surveying, geological excursions, road making, and the labors of the farm; but not being able at that time to place the school on an eligible foundation, it was abandoned (89).

Josiah Holbrook after giving up his school turned his attention to adult instruction which was somewhat like our present agricultural extension among farmers.

Our present organization of agricultural colleges is very similar to a plan for such schools proposed in Barnard's Journal of Education in 1856 by Professor John A. Porter of Yale. 
'This was the year after the act establishing the first agricultural college (Michigan) was passed and the year before it was formally opened. He deplored the lack of agricultural instruction in this country and suggested that such instruction might be supplied by having a demonstration farm, an experiment farm, and means of instruction in all sciences connected with culture of the soil. He says :

What a center of light would such a school as here described be to the whole agricultural community. All purported discoveries in agriculture would come to be tested, and important truths developed by experiment would go forth from it into the world. ... . Through its pupils it would disseminate widely the varied practical information which its courses would furnish, and beyond this, it might be made a means of eliciting the experimental labor of hundreds of intelligent farmers throughout the country, for the decision of the important agricultural questions which are still unsettled (88).

In a footnote at the end of the article the editor calls attention to an account in his National Education in Europe of the system of agricultural education established in France as it was in I854, and also to the Institute of Agriculture and Forestry in Würtemburg, and the system of agricultural education in Ireland.

Pestalozzi and his work, particularly his influence on our own school practices, receive much consideration in the journal under discussion. For example, we find the historical beginning of nature-study in this country in the object-teaching at Oswego. This attempt to put his doctrine into practice is described in great detail (89a). In another place Pestalozzi is quoted as saying with reference to objective teaching that "agricultural labor offers a wider field than any other employment for this means." This statement should be contrasted with the absurd efforts made in some schools to apply these principles. It would be interesting in this connection to trace the influence of these early objectlessons on nature-study teaching and to discover to what extent it is responsible for the struggle which nature-study has had to find a legitimate place in our schools.

The agricultural school of De Fellenburg and Wehrli was a 
school for the poor at Hopwyl, and many of the pupils were juvenile offenders of various sorts (90). Several Fellenburg schools were established in this country in the early part of the last century. The Journal brought the work of these schools in this country and in Europe into notice again. About the same time there seems to have been a revival of these methods in certain schools and institutions in this country. Practically all of the reform schools for boys in the United States are now provided with farms, and agriculture is an important part of their work. How much influence, if any, the Journal had in bringing this about we do not know. But we find it giving, on the one hand, details of such work as in the agricultural school just referred to, and on the other, accounts and discussions of reform schools and institutions for homeless children in this country (9I).

Education in foreign countries occupied a prominent place in the Journal. From time to time accounts of agricultural education in various countries appeared. A good example of these accounts is to be found in one devoted to agricultural education in France and about twenty different parts of the world. This is a part of an exhaustive study of scientific instruction applied to national industries in different countries (92).

The first group of educational periodicals-those mainly devoted to general problems of education or to publication of educational research-is quite small in number compared with the other two groups. Their circulation is also much less than most of those of the third group. Notwithstanding their small number and limited circulation these periodicals contain some of our most valuable educational literature, and are, on the whole, a source of high authority in educational matters. The attention given to agricultural education is much less than would seem to be warranted in view of the great public interest in the subject and of the fact of its rapid introduction into schools of various sections of the country. Compared with other sources the literature on this subject as found in the leading periodicals of this 
group is very meager (Barnard's Journal excepted). A few of the earlier articles discuss how agricultural education might be gradually developed in the elementary and secondary schools. Some work of an extension character was regarded at that time (I900--I90I) as the most feasible and practicable, nature-study, reading courses, itinerant schools, and short courses being suggested as the best means of creating an interest in the subject $(93,94)$.

A little later the place of agriculture in our public-school system is carefully considered with conclusions favorable to its introduction (95). In the meantime the subject is being rapidly introduced in our schools, and certain tendencies are arising that are viewed with some alarm because they are not in harmony with the national policy in school matters. An editorial in one periodical calls attention to some of the dangers arising from the establishment of agricultural high schools:

If the new type of work means the establishment of a separate system of high schools, the existing high schools will be sapped of the very means of their existence. ... There is one other and more urgent reason why a separate class of high schools must not be allowed to spring up. Just as sure as they do they will breed social distinctions and cause stratifications in society. It has been our boast that children of all nationalities, occupations, and creeds enter our schoolroom doors and emerge together as American citizens. The American public school is the greatest factor in developing American citizenship that we possess, and its function in developing American citizenship is greater than teaching arithmetic, Latin, or trades. Social efficiency is much more needed just now than business efficiency. But alas, too many are thinking only of business acumen. .... The one who argues for the establishment of a separate system of agricultural high schools or separate industrial high schools is wittingly or unwittingly an enemy to our present high schools and to true democracy ( 96 , pp. 57-59).

The implication in this editorial that existing high schools furnish all that is really needed in secondary education is open to question, and soon brings a rejoinder:

I am afraid that the distinctions are here or have got to come, and that the high schools which are nothing more than college preparatory 
schools will have to sink into relative insignificance compared with schools which will teach the masses how to make a living as well as how to live. .....We need as never before many-sided men and women, but men and women who will put how to live and how to make a living first, and how to use one's leisure second ( 97, p. 199).

At present the importance of the problem suggested in the foregoing discussion is being appreciated, and all the more because agricultural high schools continue to be established. Besides general discussions of the whole question of industrial education as related to elementary and secondary schools two plans for agricultural education in existing high schools are proposed and are being considered. For example, one writer believes in the correlation of high-school science and agriculture and gives numerous illustrations to show that "the benefit of correlation inures as well to the fundamental sciences as to their application in agriculture" (98). Another thinks that agriculture should be taught as a separate science. He says:

"Educators are coming to see more and more clearly that agriculture is both a science and an art, and as a result it is being taught in ways which are not strictly applicable to the teaching of other sciences." He sums up fifty-six replies to a questionnaire sent out to secondary-school men and college professors and concludes that a "majority who have had actual experience in teaching the subject advocate its being taught separately" (99).

Among the periodicals of the second group two are devoted to special phases of education that include agriculture. One is School Science and Mathematics and the other is the NatureStudy Review. The former is published in the interest of secondary education and the latter of elementary education. The editors and associate editors of both periodicals are well-known schoolmen who are actively interested in the various problems of education of their own special lines of work.

In a recent number of School Science and Mathematics we find among the introductory sentences of an article on biologic science in secondary schools the following: 
This is pre-eminently an age of applied science; it is an intensely practical age; the average individual comes in daily contact with problems of science as never before. It is self-evident that science work in elementary schools should play an important part in the education of our youth who go into life-as a vast majority do-with no further fitting than that received in the elementary school or secondary school. It was with this thought in mind that the writer began the following preliminary investigation which aims in the first place to present some statistics bearing upon the teaching of science, and especially of biologic science, in the secondary schools, and in the second place to suggest possible modifications in our present courses in biologic science that will make such courses a better preparation for the kind of life into which most of our young people are launching, the active life of the thinking, doing citizen (IOO).

This somewhat lengthy quotation with respect to one secondaryschool subject is given because it represents very well the general attitude of the recent contributors to this journal. Agriculture is closely allied to all of the fundamental sciences and any such modifications of science teaching as indicated in the above reference will have an important bearing on agricultural education in the secondary schools. These contributors are already teaching particular branches of science, and their writings have to do with their own subjects in relation to agriculture rather than with agriculture as a separate subject.

The general field covered by the Nature-Study Review includes, as is stated in the introduction to the first number, "school gardening and the closely allied elementary agriculture" (Iо I). This magazine is now in its seventh volume and has published numerous articles on agriculture as adapted to the elementary schools. For awhile, from September to December, I909, a special department of school agriculture was conducted. But it was abandoned, the policy now being to devote certain numbers exclusively to this subject, as in the May number of Vol. VI. ${ }^{1}$

The third group includes about one hundred periodicals in which every section of the country is represented. It is through these that the masses of the teachers are reached. In many states

\footnotetext{
"Another periodical perhaps should be included: School Agriculture, "a semi-monthly text for use in country, town, and city schools, homes and clubs," published by The Orange Judd Co., beginning January I, IgII.
} 
some educational periodical becomes a sort of official organ for the state department of education. Practically all whose subscribers are teachers in the rural schools give considerable attention to agriculture, mainly in the way of suggestions and helps to teachers. The effect of these periodicals on the actual teaching of agriculture in the public schools has been, up to the present, far greater than of any of the first or second group. One periodical, the School Nezes (Illinois), has been referred to in a previous chapter $\left(5^{8}\right)$. It was one of the first to take up elementary agriculture in response to the new demand upon the rural teachers. In I900 it began to publish short articles on various phases of agriculture adapted to the elementary schools. The practical efforts of this magazine to help the rural teachers is further shown in connection with the new course of study for the state of Illinois. This course includes agriculture. The department of the magazine devoted to school work in agriculture expands the course of study in agriculture into descriptive details and gives specific directions to teachers as to how to present the new work (IO2).

The Nebraska Teacher, besides publishing special articles on various phases of agriculture, is now publishing a series of articles by Superintendent E. C. Bishop on "Agriculture and Home Economics" ( $\mathrm{IO}_{3}$ ). These articles are intended to assist teachers in their work with the boys' and girls' clubs of the state.

Many similar examples might be given but these two are typical of the work that is now being done by many if not most of the periodicals of the third group. They are close to the teachers and seem to know what they need, or at least what they want, and give it to them in a simple and concrete way. 


\section{CHAPTER IX}

\section{PERIODICAL LITERATURE}

Popular periodicals have become an important factor in education. They reach thousands of people. Several have a circulation of more than 100,000 , and a few claim to reach a million readers. Every subject of popular interest is exploited. This popular interest determines in a large measure the choice of subject-matter, but not always. Interest in new things is often stimulated by well-written articles. Indeed there is a keen search for new things or the beginnings of new movements that may seem to have elements of popular interest. The importance of rural education, the inefficiency of the present system, and the need of redirecting rural education are new things from the standpoint of the popular periodical.

An educational system which originated in pioneer days, and which served its purpose well in those days, persists today with less modification than has taken place in any other feature of rural life. The few changes that have taken place were brought about largely through imitation, either voluntarily or impressed by law, of urban schools, and were not the changes of an adaptive growth. This static condition of rural education was until a few years ago, and is, in most communities at the present time, looked upon with complacency and satisfaction. Patrons who were not satisfied quietly moved to some town or city where their children might have better educational advantages, but little or no criticism of the rural school was ventured and little or no effort made to improve it.

With this situation in mind, it is easy to see why any departure from the established routine in rural-school management or any effort to make its work better adapted to rural conditions would be regarded by editors of popular periodicals as something new and worthy of wide publicity. 
Consolidation of rural schools began in the early nineties. Various periodicals gave accounts of the schools of Kingsville Township, Ohio, which in 1892 instituted a plan of consolidation for rural schools. This movement soon attracted much attention, and many visits were made to Ohio for the purpose of seeing the plan in actual operation. In a few years the plan was not only extended to other parts of Ohio but was introduced in many other states. It has worked so successfully as to be considered one of the most important features of any general scheme for improving rural schools.

The work of Kingsville Township was not the historical beginning of the consolidated-school movement, but it was the potential beginning, largely due to the public notice it received through newspapers and periodicals.

Superintendent O. J. Kern, of Winnebago County, Ill., had barely demonstrated the success of his Farmer Boys' Experiment Club which he had organized in February, 1902, among the schoolboys of his county, when he was asked to give an account of it in one of our leading popular magazines. This work of his was something new in a county system of schools, and furthermore it had begun at once to interest farmers and to change their attitude toward the rural schools. Winnebago County was a typical county with large agricultural interests. Its problems and interests were like those of hundreds of other counties. Superintendent Kern had found something that looked toward making the school life of the country boys more worth while, but he had much more in mind than his Boys' Experiment Club. He believed that the whole rural-school system needed readjustment and that it might be slowly brought about.

Here was a chance for the magazine to be of service by giving publicity to successful work, and for the writer to get others interested in his plans, and to get them to work along similar lines. The article appeared under the title of "Learning by Doing for the Farmer Boy" and was illustrated by five good pictures with the "boy" prominently in the foreground of 
each. The title and the pictures were attractive and were likely to cause the reader to pause in turning through the pages of the magazine long enough at least to read the introductory paragraph. This was an expression of an ideal for rural education which up to that time (I903) had not come much into public notice :

It is not the belief or wish of the writer that we should educate country boys to be farmers merely, any more than that we should educate boys to be blacksmiths, carpenters, or electricians. We should aim to train boys to be men in the highest sense of the term. But why not a course of training in the country school for the country boy which shall teach him more about country life around him? Along with his study of the kangaroo, the bamboo, and the cockatoo, why not study the animals on the farm and a proper feeding-standard for them, the care and composition of the soil on the farm, the improvement of types of grains and vegetables, and the protection of birds beneficial to the farmer? Instead of all the boys' arithmetic being devoted to problems, more or less theoretical, on banking, stocks, exchange, brokerage, alligation, and partnership, why not some practical problems with reference to farm economics? For the boys who will remain on the farm (and 85 per cent perhaps will) the course of instruction should be such as will be an inspiration and a help in their future life-work (IO4).

A year later under the title of "Common-Sense Country Schools" a description of Mr. Kern's work appeared in another magazine (105). Other references to his work have been published from time to time.

Boys' clubs for carrying on agricultural experiments have been organized in all of the agricultural states. Accounts of their work are attractive reading, and no doubt not only stimulate the boys in other localities to form similar clubs but help to educate adult farmers to be more appreciative of expert opinion. But the most important contribution made by periodicals to agricultural education through boys' clubs has been in making the way easier for agricultural colleges and public-school officers to carry on the work in various parts of the country.

In the same number of the magazine in which Mr. Kern's article appeared is another dealing with the problem of rural education (I06). The need of a school system adapted to rural 
conditions is set forth. Special emphasis is placed upon the value of agricultural high schools and of consolidated rural schools. At that time there were twelve agricultural high schools in the United States; in I9ro over seventy-five.

Another account of important work in agricultural education was published in the same year (1903) with the title "Teaching Farmers' Children on the Ground" (107). It is of interest to compare the opinion of Superintendent Kern as to the needs of the rural school with that of the writer of this article who was not professionally engaged in education. The following is taken from his description of a rural school:

But there is more the matter with the ordinary country school than its smallness of scale.... Yet that these children come from homes where the livelihood is earned out of the ground is ignored in the lessons. The instruction as far as it goes is good: it is staple reading, writing, and arithmetic, with a little grammar, geography, and history. This is all. It might do well enough if the boys and girls were all going to be clerks or traders; or if, in the fulness of their ambition, they were to strike out for professional careers. But of sowing and reaping there is never a word; nothing about planting and tending of trees, the production of milk, butter, and cheese. Never, even remotely, does a lesson touch on building and drainage, on the composition of foods or chemistry of fuel, or light up for so much as a moment the drama of struggle and survival of which every clover patch is a theater. It is well that children should learn at school useful lessons they can learn nowhere else, but should not the children of the farm be led to see somewhat of the inexhaustible scope for brains which offers itself to the farmer? The fact is, that rural instruction has been largely devised in cities with a view to city conditions. And the courses in city schools are faulty enough, ridden as they are by clerky traditions which permit the word to usurp the place of the act, instead of being merely its symbol and aid. The second evil in rural education throughout America is the stress laid upon verbal studies, the blinking of the actual world of duty and joy for which country children should be informed and trained.

This is followed by a description of the proposed scheme for the improvement of rural education in Canada planned on a scale to include the whole Dominion. Not only is this description accurate but it includes a good historical and economic 
background. This account of the "Macdonald Movement" before it was carried out in actual practice prepared the public mind for the numerous reports of the work that have appeared since.

Mention should be made of one more popular article on rural education appearing in I9O3, entitled "Farmer Children Need Farmer Studies" (I08). The title indicates the general nature of the discussion. That the writer is in full accord with the views already noted of other contributors is shown by the following statements:

Our educational system has been made for city people, and the country school finds it second hand and ill-fitting and unattractive. To this fact more than any other, perhaps, is due the backwardness of education in agricultural states.

Quoted from a private letter:

Statistics show that in this state each year sixty young men take up ministry, sixty-six law, and seventy-two medicine, while r 3,000 annually take up agriculture as a gainful pursuit. But our school books are written for the few not the many..... At present the entire curriculum leads away from the farm..... Pick up any high-grade arithmetic in use in the rural schools and you will find no lack of attention to banking and commissions and foreign exchange and commercial affairs generally. But agriculture arises to no such dignity-not even in schools that will find five times as many recruits for the farm as for the city. The same applies to other texts.

The typical examples above presented of popular periodical literature on rural education appeared in 1903. This year was chosen because it seemed to mark the beginning of a somewhat general public interest in the subject, and partly because most of the development of agricultural education in elementary and secondary schools has taken place since that time.

During the period from 1904 to the present the subject of rural education has continued to receive notice in popular periodicals (I05, I09, I IO, I I I, I I2). The public has been kept informed concerning various phases of its development, agricultural and other industrial work in schools receiving especial attention. 
One magazine addressed the following question to a number of prominent educators: "What new subject or new method or new direction of effort or new tendency in educational work is of most value and significance and now needs most emphasis and encouragement?" (II3). Nineteen replies were received. As most of the writers were college presidents various college problems were mentioned as of greatest importance but no two proposed the same problem. The only subject that was mentioned by more than three was practical education, summed up as follows: Trade work in public schools; interest in rural schools; practical studies; agriculture for rural schools; reaching all the people; teaching every man his job.

A good account of the present status of agricultural education in elementary and secondary schools appeared under the title "Catching Them Young" (II4). After describing some recent progress in farming methods the author adds:

Of what value is this knowledge if the sons and daughters are to quit the farm, leaving corn-belt prosperity to the haphazard agriculture of the city-born and of transplanting foreigners who find conditions and climate vastly different from those of the fatherland? Therefore the corn-belt has at last set itself to raising that greater and more valuable crop of farm boys and farm girls who find material comforts and ample financial recompense on the farm. The greatest factor in the raising of this new crop is education.... . But the farm boys and girls in order to be interested must be caught young. Before they are old enough to enter the land-grant colleges the lure of the city has entered their minds and the mischief is done. Raising bumper crops of corn and oats, the typically agricultural states of America have heretofore failed to raise satisfactory crops of stay-at-home boys and girls.

An editorial in another magazine revives the criticism which appeared against rural schools a few years before. It is entitled "The Martian and the Farm" (II5) and makes the remarks of the supposed Martian who is represented as visiting an ordinary country school the basis of some pointed comments on the rural schools :

I notice that these Americans seem to think the raising of crops to be quite unnecessary; and that they are applying their remarkable intelligence 
to the task of depopulating their rural regions. They have acuteness to see that if they are to drive people out of the country, they cannot begin with the adult population. Life in the open country is so alluring and so natural that even when it has not been made as complete as it might be, it holds people fast. So these far-reaching Americans, in order to crowd people back into the cities, where they obviously want them to be, have devised a campaign of education directed toward the children. They have planned all their rural schools on city models. Even in such details as arithmetic problems, they see to it that the children's minds should be directed toward urban life. . . . . If this visitor were told what he interpreted as an astute campaign was a mere matter of stupidity and tradition, and that the American People were really wondering how they could check the congestion of cities, he would be forced, out of decent respect for the people he was visiting, to be incredulous.

How can a child born and reared in the country respect the life of the farmer when the community in which he lives does not regard the farmer's occupation worthy of study? How can he be expected to look with ambition toward agriculture as a vocation when he finds that training for it is regarded as less important than preparation for a clerkship? How can he think of village and rural life as anything more than a makeshift when he finds that in the schools he attends there is not a word taught concerning crops or cattle or roads?

The situation in this country is then contrasted with the national policy of rural education recently inaugurated in Canada and the importance of a similar movement in this country suggested. The criticism of the condition in rural schools as to their indifference to rural life does not go unchallenged. In a later number of the same magazine appears a reply in which the editor is brought to task for making implications that were not warranted by the facts in the case. The work in agricultural education of the Middle West is cited as a refutation. The writer in a five months' visit in Canada had been unable to see any reason for holding up the Canadian scheme for rural education as a model for this country ( I I6).

Another letter of reply is published from a farmer who could see no more reason why "a country child should be taught how to run a farm than a city child should be taught how to run a bank." 
It seems plain to me [he says] that the public schools are intended to give the young a practical education to prepare them for life, not to prepare them for any particular work in life.... Why tax the community in general to instruct its children for work and life on the farm, when many of the patrons and many of the children themselves would prefer general education? (II 7).

The above editorial and its sequel, the two letters of reply, give some insight into the present situation. No doubt the condition referred to in the editorial does not apply to all rural schools but in general it is not much overdrawn. The writer of the first letter unduly magnifies the work of agricultural education in this country, for it has not had time to modify the ordinary rural schools to any considerable extent, even in the favored Middle West. On the other hand, his five months' visit in Canada failed to show him that the efforts of the Canadian educators are aimed directly at the rural schools. The second letter reveals an attitude which is familiar to those who have undertaken to hold up the chief interest of a rural community as a motive for better schools.

In reviewing the relation of popular periodicals to agricultural education only typical examples have been given. No attempt has been made to have the references complete. Sufficient citations have been given to indicate the character and scope of the discussions of the subject as they have appeared in these periodicals, and to show the service rendered by keeping the subject before the public, and by helping to secure a favorable attitude toward the improvement of rural schools.

Brief reference should be made also to periodicals whose circulation is limited to smaller groups of readers. There is a large number published in the interest of farmers. Most of them are local, being chiefly confined in circulation to a single state. Many are of doubtful value. Those that are really sincere in their efforts to improve farm life have exerted considerable influence for the betterment of rural schools and for the introduction of agriculture. Special articles as well as letters from sub- 
scribers are published. The most important of these are reviewed from time to time in the Experiment Station Record of the United States Department of Agriculture (I7) and need not be mentioned here except in this general way. On the whole, agricultural periodicals have maintained too conservative an attitude toward agricultural education, both as to colleges, and to elementary and secondary schools. One cannot avoid the suspicion that this attitude on the part of some of these publications is not wholly disinterested. Agricultural education would, among other things, most certainly develop more critical readers, and this would soon react upon the circulation or upon the character of the matter published. Again, the fear of offending some of their readers, thus affecting circulation, makes the publishers cautious in giving space to views that might unsettle the faith of the fathers in the little one-room school.

Occasionally a well-written article on agricultural education appears in the more special periodicals. For example, in a magazine "devoted to the philosophy of science" we find a discussion of "Agriculture the Basis of Education" (II8). The writer regards the two primal contacts of the child, with nature and with parents, as more fundamental than all questions of subjectmatter and methods of formal education. "The mental conditions of agriculture are just as essential to normal development of the human mind as air, food, and exercise for the development of the human body." $\mathrm{He}$ refers to the education of the early Greeks in support of his views: "The young Greek of the Homeric age appears to have had much more intimate and adequate contacts with nature and with his elders than our modern education provides, or even permits."

A similar conclusion as to the educational influence of agriculture, though discussed from an entirely different standpoint, is found in an article on "Farm Life as a Basis of Practical Education" (II9). The subject for another discussion is the "Need for Agricultural Education" (120). The economic im- 
portance of this kind of education is urged. Another point of view is set forth under the title "Rural Education" (I2I).

Rural education is but a section of the general school question; agricultural education is a branch of technical training. These two phases of education of the farm population meet at many points, they must work in harmony, and together they form a distinct educational problem.

Three difficulties are mentioned: (x) To secure a modern school equal to the city school; (2) to enrich and expand the curriculum so as to make it a vital and coherent part of ruralcommunity life; (3) to provide adequate high-school facilities in the rural community. 


\section{CHAPTER X}

\section{STATE ORGANIZATIONS FOR AGRICULTURE-FARMERS' INSTITUTES}

Perhaps no other offices concerned with the public business of various states include so wide a range of activities, duties, aims, and methods as do the state organizations for agriculture. One state commissioner of agriculture says of his department:

If I were asked to supply a name, it would be called the Dumping Ground for a Legislature to place all subject-matter that body finds necessary to frame into law.

The justice of this observation will be more readily appreciated by reference to the following constitutional provisions for his office:

He shall perform such duties in relation to agriculture as may be prescribed by law, shall have supervision of all matters pertaining to the public lands under regulations prescribed by law, and shall keep the Bureau of Immigration. He shall also have supervision of the State Prison, and shall perform such other duties as may be prescribed by law.

Some state organizations for agriculture have even a wider range of duties. On the other hand, there are some in which the duties of this office are limited to the supervision of the state agricultural college, or to the management of the state fair.

There are five forms of organization. The first includes those organizations known as "Departments" and consists of a commissioner and one or more assistants. The second form comprises the boards, which are composed of a varying number of members, some appointed by the governor and others being members of the board by virtue of their official position in the state. The third includes bureaus which are essentially the same as the boards. The fourth form is a combination of the first and second; the regular department is supervised by a board of agriculture. The fifth and final form is that known as the Michigan organization, under which the state board of agriculture is merely a board of trustees for the state agricultural college (122, p. 328). 
In about half the states the administrative officer is chosen by popular vote; in the rest he is appointed by the governor or chosen by the members of the board. Being thus a political office in some instances, the position as secretary or commissioner of agriculture is more or less on a political basis, and therefore fails properly to fulfil the purpose for which it was intended, viz., to promote the agricultural interests of the state. It is the purpose of this chapter to sum up the work now being done by the various state departments, and by the state farmers' institutes in promoting agricultural education, particularly in elementary and secondary schools.

In one-half of the states the farmers' institutes are conducted under the direct or indirect control of the state organizations for agriculture; in the other half they are conducted by the state agricultural colleges. Since the methods and aims of all farmers' institutes are essentially the same in both groups, those under state supervision and those under state agricultural college supervision will be considered in the second part of this discussion. As might be expected, the attitude of the various state organizations for agriculture is favorable toward agricultural education in the public schools. In many reports of secretaries or commissioners of agriculture much emphasis is placed upon the importance of recognizing agriculture as a school subject. The following extract is typical:

The Department has continued its efforts to impress upon the people of the state the importance and necessity of agricultural and industrial instruction in the public schools. These schools should fit for vocation. The population of this and other states is continually increasing, and in order for the farms to meet this increase there must be a more intelligent system of agriculture. This can best be brought about by teaching the principles of agriculture in the public schools. The farmer has a business to be studied and learned. It needs a trained mind as much as any oth $r$ occupation. Let us educate our boys who are to be farmers of the future, for that work. Specific training of a practical kind is a necessity for the coming occupants of our farms, as well as those engaged in mechanical industries. The most valuable asset of the state is her children. They 
should be trained to high ideals of every day living and to high efficiency in their respective vocations (I23, p. II).

At the annual meetings of boards of agriculture of several states agricultural education receives attention, special addresses being given on this subject and published in the proceedings (124, 125, 126, 127).

Special bulletins or leaflets are published and distributed by a few state offices of agriculture. The Massachusetts State Board of Agriculture has issued from time to time leaflets on elementary agriculture and nature-study. The New York State Department of Agriculture publishes annual reports of the state Experiment Station at Cornell University. These contain reprints of various nature-study, rural school, and teachers' leaflets sent out from Cornell University, and also accounts of the extension work in agriculture and naturestudy conducted by the university among the schools of the state. The Missouri State Board has recently published a bulletin on elementary agriculture meant to be used "only as the first year's work," and "written on the supposition that neither teacher nor pupils know much of scientific agriculture" (128).

About half of the states hold annual state fairs under the management of the state offices of agriculture. In nearly all, there is a department of education in which prizes are offered for school exhibits. Some give special encouragement to agricultural subjects. The prizes amount to a few dollars in some fairs and to several hundred in others.

The Nebraska State Fair offered "to the Nebraska boy under eighteen years of age, growing the largest yield of corn from one acre of ground, in the year I910, $\$ 50$; second, \$25; third, \$20; fourth, \$15; fifth, \$10; and to the sixth, seventh, eighth, ninth, tenth, and eleventh, \$5 each."

The South Dakota State Fair made the boys' and girls' contests a special feature at its recent meeting. Three hundred and fifty dollars were offered in cash prizes, the largest first 
prize being one hundred dollars. The contest was announced in a special bulletin containing instructions as to the details of preparation for the contests (129).

One of the most popular buildings at the last Minnesota State Fair was the Agricultural Hall Annex which was devoted entirely to the exhibits in agriculture, household arts, and manual training of the ten high schools receiving state aid for teaching these subjects.

The Oklahoma State Fair of I9Io arranged for a school of agriculture to be held on its grounds. Each county is entitled to two delegates, one hundred and fifty-four boys being provided for. "This work will be done at the fair grounds. The boys and instructors will sleep in a large tent." A portion of each day is to be devoted to instruction, lectures in the mornings and object-teaching or laboratory work in the afternoons (I30). A similar school for boys is conducted by the Illinois State Fair (I3I).

Contests, for example, corn contests, are held in some states under the direction of the state office of agriculture. Such contests are being held in Missouri this year all over the state, and a Farm Boys' Encampment is conducted under the same management. In South Carolina contests have been held throughout the state under the joint direction of the State Department of Agriculture and the United States Demonstration Work. In the state contest which is soon to take place over three thousand boys are enrolled. The winner of last year's contest, Bascomb Usher, raised on one acre one hundred and fifty-two and onehalf bushels of corn. The average production of corn per acre for the entire state was about eighteen bushels. A number of other southern states are conducting similar co-operative contests (see chap. xii).

South Carolina, through its Department of Agriculture, has been aiding the practical teaching of agriculture in a few high schools by maintaining a skilled teacher and operating a farm 
and practice garden in connection with the school (132). The commissioner says :

This has been in the nature of an experiment, but we have gone far enough in the matter to see that admirable results may be obtained, and at a very minimum of cost. The only cost, in fact, to us is the salary of the man nine months in the year. The land is furnished by the patrons of the school, as are also the work animals, implements, fertilizers, etc., and the school is given the profits from the farm.I

These are typical examples of the work of various state offices of agriculture in promoting an interest in agriculture and rural life among boys and girls. Many others might have been given. It is a new field of activity for these offices, and promises much if organized and extended so as to co-operate with other educational efforts. Perhaps the greatest value of such work for agricultural education to the public schools lies in placing the stamp of official approval upon this kind of education.

In many states practically nothing has been done by these offices, and in none more than a beginning of what might be done. The state and county fairs, for example, offer unusual educational opportunities. If the same energy now expended in managing and controlling amusement-park features of these fairs (which are of doubtful value at best) were directed toward helping the schools of rural communities there might be a great educational gain for the state (I33).

\section{STATE FARMERS' INSTITUTES}

The farmers' institute movement in the United States has now reached a degree of importance and development that places it along side of the leading institutions of the country organized in the interest of industrial education. Forty-five states and territories held institutes in 1905, aggregating 10,555 half-day sessions, which were attended by 995,192 persons, chiefly adults (134, p. 7).

The growth of this movement may be seen by comparing the above summary for 1905 with the following summary for 1908: number of institutes 4,643; half-day sessions I3,056;

\footnotetext{
${ }^{3}$ Quoted from private letter.
} 
attendance $2,098,268$. In addition to the regular institutes included in the above a number of special institutes were held with an attendance of 340,4 I 4 , which, added to the attendance at the regular institutes, make a total of $2,438,682$. There is no record of attendance of 732 meetings of women's institutes, of I74 meetings of boys' institutes, or of several other meetings which might be regarded as farmers' institutes (I35).

The function of the farmers' institute is to educate the people on their own ground. It is a phase of extension work that carries education directly to the localities in which the people live. It deals less with individual men on their farms than with small communities or groups of men; it therefore has the opportunity to exert great influence in developing the social life of rural neighborhoods (122, p. 462).

With these aims on the one hand, and with an attendance of over two million on the other, farmers' institutes become a factor in rural education second only to the public schools. Although the institutes are intended for adults it must be remembered that adults are patrons of the rural schools, and wherever the farmers' institute arouses the adult population to a realization of a need for better schools, improvement in these schools is likely to follow.

In 1896 the American Association of Farmers' Institute Workers was organized and has held annual meetings ever since. This association is a sort of clearing-house for exchange of ideas and methods, and is intended also to secure a more or less uniform type of institute in the several states. In 1898 the association requested the secretary of the Department of Agriculture at Washington to arrange for a division in connection with the department to be known as the Division of Farmers' Institutes. This request was subsequently granted by establishing the office of Farmers' Institute Specialist. ${ }^{2}$

The general policy of farmers' institutes is influenced greatly by the association and by the office of Farmers' Institute Specialist. At the meeting for 1908 , the

- The work of this office was referred to in chap. i. 
subjects for discussion in the general program were mainly directed toward defining the status of the farmers' institute in its relation to other forms of agricultural education. The points brought out were that the farmers' institute occupies the position of field agent for agricultural education; that it provides a most efficient channel for carrying agricultural information directly to the farmer who is unable to leave his occupation to go to school; and that it should broaden its work until it embraces other more advanced forms of educational work and extend its efforts until all rural people have full opportunity to enjoy its benefits ( 135, p. 293).

Farmers' institute workers are further assisted by state meetings where they gather together to plan the year's work. Here the policy for the work of the whole state is determined. In many of these meetings the relation of the institute to the public schools receives attention, and methods for assisting the introduction of agriculture and other rural-life subjects into the rural schools are discussed.

The following extracts of letters from some state directors or superintendents of farmers' institutes will indicate more definitely what these institutes are doing in this matter:

In connection with the Farmers' Demonstration Train we always send preliminary notice to the schools where the train is scheduled to stop, inviting them to have their pupils visit the train (Cal.).

At our annual conference of institute workers, the question of the relation of the school and church to the farm and rural life receives due consideration. The result is that an atmosphere favorable to the development of the schools along practical lines is pretty generally diffused (Ind.).

The farmers' institute lecturers have encouraged institute patrons to insist in their respective counties that agriculture be taught in the public schools (Md.).

Not only is this subject discussed by many of the lecturers, but at a large number of the institutes special speakers upon this and allied subjects are provided (Mich.).

For two years we have been giving lectures in agriculture and allied subjects in the high schools of the state; last year to the extent of eighty. Plans are nearly perfected for increasing this line of work the coming season, giving lecture courses consisting of four lectures in each of such schools as apply for them (Mont.). 
We have several speakers who lecture before evening sessions of farmers' institutes on such subjects as: agriculture in the rural schools, domestic science in the rural schools, value of agricultural education, etc. (Neb.).

Each of the four corps of institute lecturers is accompanied by a representative of the Educational Department who arranges for special sessions in the public schools in connection with institutes where he can secure cooperation of the local school authorities. At these special sessions the farmers' institute lecturers give talks on elementary agriculture and naturestudy. The total attendance at these special sessions held during the school periods amounted to 22,697 (N.Y.).

When we are holding an institute in a town we very often send the lecturers to the schools to speak to the school children on certain phases of farm life (N.D.).

No instructions are given institute lecturers regarding this work; however, at many institutes teachers and pupils are called to the meeting and special lectures are given them (Okla.).

We are trying to give a good deal of attention to the introduction of agricultural education in the public schools. I have attended ten teachers' institutes during the summer with this object in view, speaking at some of them three times, and I think the subject has been discussed by some person in every institute in the state (S.D.).

Our farmers' institute instructors do what they can to promote and encourage the teaching of agriculture in the rural schools. Many of them have lectures upon this subject (W.Va.).

For the last twenty-four years a great deal of attention has been given to the discussion of agricultural education in the public schools of Wisconsin by the farmers' institute workers of this state; in fact, we feel that public sentiment among farmers has been developed by these discussions until Wisconsin has, we think, a little more practical agriculture in her schools, from the rural district up through the county agricultural schools and the agricultural college, than has any other state in the Union (Wis.).

In most states where the farmers' institute is conducted by the agricultural college there is a close correlation between this department and that of agricultural extension. In some colleges they are practically identical. As has been indicated in chap. v, provision is made by several colleges for extension work among the schools. Where this arrangement obtains, the farmers' insti- 
tute workers merely co-operate with those engaged in the work among the schools, and do not initiate any work themselves.

From what has been presented concerning the organization and work of the farmers' institutes it will be seen that they have been a considerable factor in the movement for agricultural education in the public schools, first, by arousing favorable sentiment among the farmers, and second, by direct help to teacher and pupils.

While these institutes will doubtless continue to encourage the introduction of agriculture into the public schools and emphasize the importance of re-directing rural schools, in many states, and soon in all the agricultural states, the demands of the rural schools for help along industrial lines will require some special attention not now provided. 


\section{CHAPTER XI}

\section{AGRICULTURAL SOCIETIES}

The development of agricultural societies may be divided into four periods: (I) from 1785 to 1850 -the period of beginnings; (2) from 1850 to 1870 - the period of agricultural fairs; (3) from I870 to 1892 - the period of great organizations; (4) from 1892 to the present-the period of adjustment (I22, p. 29I).

\section{FIRST PERIOD}

The first period in its relation to agricultural education is an important one, particularly in its historical significance. The influence of these early societies on agricultural education is perhaps greater than that of any other single factor contributing to its development. The idea of such an education is regarded by some as originating in these societies. That it was much exploited by them is certainly true. The idea persisted and grew, and may be followed from this early period to the establishment of land-grant colleges. The idea persists today, but modified to include elementary and secondary education.

In 1785 the Philadelphia Society for the Promotion of Agriculture was organized, and later in the same year a similar society was formed at Charleston, S.C. Within the following decade a number of other societies was organized. Among the members of these societies were many prominent men such as George Washington, Benjamin Franklin, and Timothy Pickering. These men were also interested in education. It is not strange that the two interests should be combined in their minds into the idea of agricultural education.

Benjamin Franklin had given expression to this idea many years before the founding of the first agricultural society. Referring to the education of the youth of Pennsylvania he says: 
While they are reading natural history might not a little gardening, planting, grafting, inoculating be taught and practiced, and now and then excursions made to the neighboring plantations of the best farms, their methods observed and reasoned upon for the information of youth, the improvement of agriculture being useful to all and skill in it no disparagement to any? (122, p. 36r).

This idea was first put into actual practice in 1792 when agriculture became a subject of instruction in Columbia College. This was brought about chiefly through the agitation of the New York, and other agricultural societies. Another example of the attitude of these early societies toward agricultural education is found in the action of the Philadelphia Society in I794. The society appointed a committee to outline a plan for establishing a "State Society for the Promotion of Agriculture, connecting with it the Education of Youth in the knowledge of that most important Art while they are acquiring other useful knowledge suitable for the agricultural citizens of the State." The plan which was drawn up and presented to the society includes some very definite references to agricultural education. Agricultural information was to be disseminated in whatever manner the legislature should think best, "whether by endowing professorships to be annexed to the University of Pennsylvania and the College of Carlisle, and other seminaries of learning, or for the purpose of teaching the chemical philosophy and elementary parts of the theory of agriculture." County societies were to be created with "county schoolmasters" as secretaries; and the schoolhouses the places of meeting and the repositories of their transactions, models, etc. "The legislature may enjoin on these schoolmasters the combination of the subject of agriculture with other parts of education. This may easily be effected by introducing, as school books, those on this subject, and thereby making it familiar to their pupils" (122, p. 363). The fact that the plan of the committee was rejected does not alter its significance in its bearing upon subsequent developments in agricultural education. It is especially noteworthy that the plan proposed is in harmony with some present-day practices: the rural school as a 
community center, correlation of agriculture with other school subjects, and agricultural textbooks.

During this entire period the subject of agricultural education was much discussed. Various plans were proposed for its development. Some provided that the societies themselves should organize stock companies to establish schools for instruction in agricultural subjects. Several such schools were started, but owing to difficulties (chiefly financial) they were not successful. These attempts were an important stage in the evolution of the agricultural college.

Stock-company plans were succeeded by others involving state or federal support. The agricultural societies representing associated effort were finally able to secure the attention of legislative bodies. In New York State, for example, the New York State Agricultural Society began a campaign for a school of agriculture soon after the date of its organization ( 1832 ), and continued it until 1853 when the legislature granted a charter for such an institution. The founding of the Agricultural College of Cornell University was no doubt due in a large measure to the activity of the New York State Agricultural Society, and of other agricultural societies of the state.

The Michigan State Agricultural Society which was formed in 1849 immediately set to work to secure a state agricultural college. Its efforts at once secured the attention of the legislature. The matter was brought up at each session of the legislature until, in 1855 , a bill authorizing the establishment of the State Agricultural College of Michigan became a law.

"The Industrial League of the State of Illinois," chiefly composed of farmers, had much to do with the passage of the Land Grant Act of 1862. This League was an outgrowth of the meeting of a convention held at Granville, Putnam County, Illinois, November I8, I851. The object of this convention "was to take into consideration such means as might be deemed most expedient to further the interests of the agricultural community, and particularly to take steps toward the establishment 
of an agricultural university" ( I36, p. 20). Jonathan B. Turner proposed a plan at this meeting which included "a university for industrial classes in each state in the Union." The plan adopted was published and widely circulated throughout the country. Another convention was held at Springfield, Illinois, June $8,185^{2}$. At this convention a memorial was presented, containing, among other things, a definite plan for organizing agricultural colleges: "An appropriate endowment of universities for the liberal education of the industrial classes in their several pursuits in each state in the Union" ( 136, p. 22). A third convention was held at Chicago, November 24, 1852 . It was decided at this meeting to organize "The Industrial League of the State of Illinois" for the purpose of forwarding the objects of the convention, one object being "to obtain a grant of public land to establish and endow industrial institutions in each and every state in the Union. "A fourth convention was held at Springfield on January 4, 1853. Here a final plan was approved in the form of a petition to Congress ( $136, \mathrm{pp} .24$ and I04). Copies were distributed to the various other agricultural and industrial societies throughout the country. These societies were asked to adopt the plan and urge its approval by Congress. The campaign for passage by Congress of an act embodying this plan was actively continued by the Industrial League of the State of Illinois, and by similar organizations in other states until it became a law, July 2 , I 862 .

The activities of the agricultural societies of New York, Michigan, and Illinois in promoting agricultural education is typical of what was accomplished by similar societies in Pennsylvania, Connecticut, and other states during this period.

\section{SECOND PERIOD}

In 1858 there were over 900 agricultural and horticultural societies listed at the Patent Office, and in I 868 the Department of Agriculture listed I,350. All but about Ioo of these were organized after I849 (I22, p. 292). 
The chief interest of most of these societies was in holding fairs. In many ways these fairs were of considerable educational value, especially in diffusing new ideas, in furnishing an opportunity for social intercourse, and in introducing better farm practice and new types of farm products. Often addresses by prominent speakers were provided as special educational features.

On the whole this period was marked by a great development of organized effort, including associations of many kinds, and ranging from national organizations to mere local farmers' clubs.

\section{THIRD PERIOD}

This period is characterized by large associations, national in scope. It represents a stage in development when agricultural people began to recognize the importance of "getting together," and of using co-operative means for securing better business and educational opportunities, and more favorable legislation. This was undertaken through large formal organizations, through co-operative concerns which were intended to do away with the "middleman," through activity in politics, and through education, directly by means of colleges and other schools, and by means of discussions and publications. Several large organizations constituted the machinery of this movement, the most important of which were the Grange and the Farmers' Alliance.

The Grange was founded in 1867 , and became a national society in $1873 .^{1}$ It is a very complete organization with the lodge as a unit, subordinate to the County Grange which is subordinate to the State Grange, this in turn being subordinate to the National Grange. The purposes are fraternal, social, educational, political, and financial. Educational work is a feature of each meeting, a certain part of the program being devoted to this subject. Sometimes the educational work of the lodges of a whole state is planned definitely by one of the state officers, the state grand lecturer. The meetings of the lodge are often held

'D. W. Aiken, The Grange-Ils Origin, Progress and Purposes, U.S. Dept. of Agric., Misc. Ser., Special Report 2; Charles W. Pierson, "Rise of the Granger Movement," Pop. Sci. $M$ Oo., V, 32, p. 199. 
in schoolhouses, thus making the school property a community center for adults as well as children. The interest of the Grange in the school does not stop with the use of the schoolhouse as a meeting-place, but it lends its support to all measures intended for the betterment of rural education, and particularly to those involving a greater use of country-life subjects. The Grange was for a time a very powerful society, but by 1880 its power as a national organization was lost. ${ }^{2}$ It declined rapidly both in membership and influence until ten years later when it began to revive again.

The Farmers' Alliance was somewhat similar to the Grange in plan and purpose. Its activity however was chiefly directed toward securing better legislation favorable to rural interests, mainly financial. Soon after the formation of the Populist party little was left of the Farmers' Alliance as an organization.

\section{FOURTH PERIOD}

With more than a century of experience agricultural societies are now being readjusted to secure for all interests of agriculture and rural life advantages that may be secured only through organized effort. They may be classified into three groups: national, state, and local. A large number of each group is devoted to some special agricultural interest, such as bee-keeping, apple production, sheep-breeding, and the like, almost every conceivable phase of agriculture being represented by an organization.

Of the national societies the Grange is perhaps the most important. Since 1890 it has emphasized social and educational features, and has recovered from the decline of the previous decade. Its interest and influence in educational matters are greater than ever before.

- The rise and decline of the Grange is well illustrated by the number of granges organized each year in Illinois for a period of eight years:

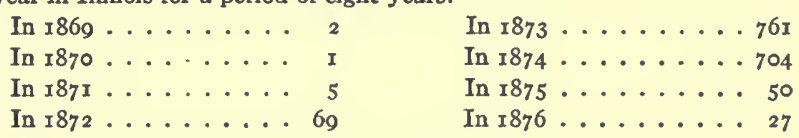
p. I0.

A. E. Paine, "The Granger Movement in Illinois," Univ. of Ill., Bull. V, 2, No. 2 (1904), 
There are now over seven hundred state agricultural societies most of which are devoted to special interests. In some states the state society has no connection with local societies, but in others the state organization is made up of representatives from local societies.

The latter plan is well illustrated by the Michigan State Association of Farmers' Clubs. In 1908 the state association included one hundred and twenty clubs from thirty-two counties. In 1908 these clubs had a membership of over seven thousand. The association holds an annual meeting in which a majority of the associated clubs are represented. The program consists of reports of various clubs, several addresses on subjects of general interest to farmers, and reports of committees.

A good example of the work of a local club is shown by the following synopsis of its annual report to the association:

The club is eleven years old, with a membership of $7 \mathrm{I}$, and average attendance of 50. Annual dues are ten cents per member; the club holds twelve meetings a year, all-day meetings from October to April. Men's meetings in February, May; temperance meetings in February, March; young people's meetings in April; ladies' meeting in May; club fair in October; picnic in August. The club publishes a paper called the Rural Grit (137, p. 15).

The addresses at the annual meetings are on topics of general interest to farmers, often on agricultural education. The most important committee is the one on resolutions. Some recommendations directed toward legislation are usually found in its reports.

The published proceedings of the various agricultural societies contain important contributions to the literature of agricultural education. The importance lies not so much in the new points of view or new ideas presented as in the fact that these articles indicate the attitude of the most progressive farmers on this question. The Report of the Proceedings of the New Jersey Horticultural Society for I9Io contains a discussion of "What Shall We Teach the Farmer's Child?" ( 138 ). A scheme is proposed for dividing the school year into more equal periods 
between farm practice and school work. The difficulty of applying such a plan is found in the present long high-school year and short vacation period, and in the absence of instruction in agricultural subjects. The author may have had in mind some shop work, as is being introduced in Cincinnati, and in other places.

The idea is suggestive of possibilities that might be developed in rural schools to advantage, provided the long vacation period were spent in applying the scientific principles of agriculture to farm practice. The boys of the Baltimore County (Md.) Agricultural High School carry on extensive experiments on their home farms during vacation periods. Their work is inspected from time to time by the teacher of agriculture in the high school, the teacher being employed to give his time during the entire year to school matters. This plan has been in operation only one year, but the results have been very satisfactory. Such an arrangement would do away with some of the objections to the present system of education raised by the above paper, that the

high schools are simply feeding the boys and girls to universities and general colleges, but unfitting them for the practical duties of life..... One great trouble with farming today is the fact that for half a century or more country teachers have worn the label and wire of an education arranged for a town school. The material benefits of education, such as they are in a public way, and the public spirit of it, have been town bred and built. One great reason why farming of late years has become more hopeful and prosperous is because we are at last developing a definite form and spirit of farm education.

There are so many societies publishing proceedings that no further reference will be made except to refer to the fact that the discussions appearing in these proceedings on instruction in agriculture in the public schools usually favor such instruction, but not always. Occasionally views are expressed against it. In the Proceedings of the Iowa Horticultural Society for 1909 we find an example of the latter (139). The writer reviews the conditions of the Iowa rural schools. His own county has 
208 rural schools. He regards the introduction of agricultural instruction in these schools as impossible, even if desirable. He would improve the teaching of these schools by placing more emphasis on the "three R's." He says, "the most persistent and able advocates of agriculture in the public schools are teachers and professors in our state and other colleges." This is not an isolated example of the conservative attitude of the farmer toward education. Similar views are held in every farming community in the country. The little one-room school is regarded as necessary for any scheme of rural education. If the scheme does not fit into the existing system it is unworthy. Much of the opposition to consolidation is no doubt due to the reluctance of abandoning the single-room school, and to the inability to see how a readjustment of school affairs can be brought about.

The sentence just quoted referring to "teachers and professors" advocating agricultural instruction shows a little of the resentment that has grown up lately in several parts of the country toward the activity of those interested in the promotion of agricultural education in the elementary and secondary schools. A prominent agricultural journal has recently cast some reflection on the motives of some of the men now engaged in agricultural extension among public schools, intimating that the matter is being agitated for the benefit of agricultural colleges. The editor finds some sympathy among his readers, as evidenced by a protest from one subscriber against so much space being given to school matters, and so little being given to the discussion of sheep-killing dogs!

Particular mention should be made of the work of the Massachusetts Horticultural Society in its relation to the schoolgarden movement (I40). Soon after Henry L. Clapp introduced school gardening into the George Putnam School of Boston, the Massachusetts Horticultural Society began to encourage the establishment of school gardens in other places in New England by offering prizes for the best gardens entering competition, and 
by giving prominence to the subject in its published proceedings. Since r893, one feature of its annual meeting is the session devoted to hearing reports on school gardens. The growth of the school-garden movement of the United States owes much to this society.

The following are a few extracts from letters written by officers of some agricultural societies in answer to an inquiry as to what their societies are now doing toward promoting agricultural education. These are typical expressions, and are taken at random from a number of replies:

Our meetings are always public and we invite teachers, students, and the general public to attend the sessions. We have not taken any definite steps toward the teaching of agriculture or horticulture in the schools, although whenever occasion offers, we are glad to say a word favoring the movement (Vermont).

We have held sessions at the State Normal Schools and have had addresses that we thought would be of value to prospective teachers (New Jersey).

We think it is an important subject and hope to see more of at least the rudiments of horticulture taught in the schools soon (Kansas).

We have papers and discussions in nearly every volume we publish regarding horticultural subjects, bearing on their relation to the public schools (Illinois).

We have undertaken recently the task of improving in some measure the grounds surrounding the rural schools of the state. We have realized for years the deplorable conditions in this respect; the lack of adequate playgrounds; the lack of order and even common cleanliness, the utter lack of any decoration, and other things too numerous to mention. We are feeling our way carefully and so far have but little to report. We have selected seven districts widely separated and for these schools we furnish landscape plans and trees and shrubs to plant the same. We also furnish expert superintendence and inspection. So far the work has been very discouraging on account of the lack of co-operation or even friendly spirit on the part of school officers and teachers. We hope, however, for better things and intend to keep on (Wisconsin).

The brief account just given of agricultural societies is sufficient to indicate at least some of their most important relations to 
agricultural education, and to impress upon the student of rural education the value of their influence in any movement affecting the country schools. Being composed of representative members of the very communities that are supposed to be benefited by improved rural education, their point of view in educational matters must be considered in any plans to bring about better rural-school conditions and their co-operation is needed for an attempt to carry out these plans. 


\section{CHAPTER XII \\ BOYS' AGRICULTURAL CLUBS}

The actual introduction of agricultural subjects into the public schools has developed along two lines, one indirect and informal, the other direct and formal. They may be regarded as two stages of one development, for experience seems to indicate that creating an interest informally by means of boys' agricultural clubs is often, if not always, the most successful method of introducing the study of agriculture into the schools of a community.

Indeed, in many places where formal instruction has failed boys' clubs have been a great success. This is well illustrated in Louisiana. In that state, although the teaching of agriculture has been required since $\mathrm{I} 898$, it has not received much serious attention in the elementary schools. But boys' clubs are being organized in every parish in the state, one parish school boys' club, for example, enrolling during the present year 555 members. This form of agricultural instruction is extending rapidly over the entire country, and is becoming a very important extension work in education as well as in agriculture. It tends to ally itself more and more with the public schools, until finally some more or less formal instruction becomes a regular part of the school work.

Thus in Ohio the state superintendent of agricultural extension work writes that most boys' and girls' club activities are now conducted as a part of the school work and that agricultural clubs as such are becoming a thing of the past, so that no separate records or statistics are now generally kept in the state (I4I, p. I2).

Two good accounts of the agricultural club movement have been published by the United States Department of Agriculture, one tracing its development to I9O4 (6I), the other from I9O4 to I9Io (I4I). The following discussion will therefore be con- 
fined chiefly to the present status of the movement with typical examples of successful work, and to the reaction of the agricultural clubs on rural education.

Various agencies have taken the initiative in starting this movement under particular local conditions, but the inspiration for state-wide activity in these lines has generally come from some individual or official source connected with the state department of education, the state agricultural college, or the United States Department of Agriculture. In the absence of such initiative the work has sometimes begun in the zeal and wisdom of some county officer or association, as the county superintendent of schools, the farmers' institute society, the county fair association, or teachers' association, the Grange organization, or the Young Men's Christian Association. Experience has shown that the work has always been most permanent and productive when it has resulted in a definite local organization, preferably under the leadership of the county school superintendent (I4I, p. 7).

Reference has already been made to the work of the state and college extension departments, of state departments of education, and of other agencies in the organization of these clubs $(37,39,4 \mathrm{I}, 43,6 \mathrm{r}, 142)$.

During the present year (I9II) this work has been extended, and is becoming better organized. In 1909 there were clubs in twenty-eight states with a total membership of approximately I 50,000. During the present year many new clubs have been formed, and the membership in many of those already organized has increased. An instance of the latter is found in the increase in membership of one club from 17 in 1909 to 555 in 1910. In the above estimate for 1909 several states that now have clubs are not included. For example, Kansas has one or more clubs in each county, with a total membership of more than 5,000 . The eleven southern states that had a membership of about I3,000 in 1909 have this year nearly 50,000 enrolled. The total membership of I9IO for the entire country may conservatively be estimated at more than 300,000 .

The most important recent development is that of the Boys' Corn Club work in the southern states. This work was undertaken by representatives of the United States Bureau of Plant 
Industry through county superintendents of education four years ago. Three years ago it was extended in a few counties of the Gulf states where the boll weevil was damaging cotton crops. At the beginning of 1909 a systematic plan was undertaken to organize boys' corn clubs in a few counties in each of the southern states. There were enrolled I2,400 boys. During I9Io in response to further demands the organizations have been extended into nearly 600 counties, with a total enrolment of 46,225 boys. Although no statistical summary of the work has been issued, a number of reports have been received by the department which show excellent work. In one county in Mississippi 48 boys produced an average yield of 92 bushels per acre; 20 boys in one county of South Carolina made I,700 bushels of corn on 20 acres. Another club of 142 boys produced an average of 62 bushels to the acre, several going above Ioo, and two or three above I 50 bushels. ${ }^{1}$

The Boys' Corn Club work is the Junior Department of the Government Demonstration Work now being carried on in all the southern states. The results of the boys' work have attracted the attention of the entire country. Considerable prominence was given to it by the public press in 1909, but much more to the results of I9ro, particularly to the remarkable achievement of Jerry Moore of Winona, S.C., a boy not fifteen years old, who produced $2283 / 4$ bushels of corn on one acre of land, this being the second largest yield per acre in the history of corn production. ${ }^{2}$

The crowning event of the work of I9IO was a visit to Washington on December I2, I910, of the prize winners from eleven southern states. They were awarded diplomas of merit by the Secretary of Agriculture, presented to the President of the United States, and personally conducted by O. B. Martin,

"The above facts were furnished in a letter from O. B. Martin, government assistant in charge of Boys' Demonstration Work. A full account of this work has since been published (15).

'Results of rgog: Youth's Companion, April ro, I9ro; Results of roro: Associated Press account, Chicago Record-Herald, December Ix and r8, rgro. 
assistant in charge of the Junior Demonstration Work, over the city of Washington, visiting all places of interest.

The relation of this work to the schools is indicated by the following extracts from directions for organization and instruction sent out by the department:

Where this work is being introduced in a county, the county superintendent of education and teachers can reach the boys in all sections of the county more quickly and more effectively than any other agency. The superintendent can explain the plan to the teachers, and they can explain it to the boys and secure the names of all the boys who will agree to plant one acre of corn.... Just as soon as the names of all the boys are assembled in the office of the county superintendent of education, duplicate lists should be sent to Dr. S. A. Knapp, Washington, D.C., who has charge of the Farmers' Co-operative Demonstration Work. These boys will from time to time receive circulars of instruction and information in regard to preparation, fertilization, cultivation, seed selection, etc. These circulars furnish excellent subject-matter for discussion at a club meeting, or for a lesson in school. They lead to further study of farmers' bulletins and books. A boy will profit much from such lessons, discussions, and books, because he is making practical application of the principles taught. $\mathrm{He}$ learns scientific agriculture because he needs it, and not because it is scientific. ... . The object of the Boys' Demonstration Work is the same as that among men, namely, better methods of farming and greater yields at less cost. Many of the boys in the clubs who begin to study agriculture in this way will continue the study in agricultural colleges; others will continue such efforts on their farms, and all of them will make useful and more effective citizens. ${ }^{3}$

The organization of the clubs in various states differs somewhat in details, but in general there is a close co-operation between the state departments of education and the state agricultural college. A good example of a state organization is the Farm-Life Club Movement in Alabama:

The leading objects of the Farm-Life Club Movement are educational and for this reason it is our desire to make this movement have a close and vital connection with the work of the county superintendents of education, the teachers, and the schools of the state. There are many important educational problems in Alabama today, but the largest one is the question

\footnotetext{
'From mimeograph directions sent out by O. B. Martin, assistant in charge of Boys' Demonstration Work, June r, 1910.
} 
of better farming. In beginning the work in a county we first secure cooperation of the superintendent and through him interest the teachers. The work is discussed at a teachers' institute and later a letter is mailed requesting each teacher to interest the boys in his school and his community in this work. The names of the boys are sent to the county superintendent by the teachers.

This work furnishes the greatest opportunity yet launched for the county superintendents and teachers to be of invaluable service to the people in arousing interest in better farming and in improved agriculture.

The ultimate purpose of the work is to aid the great movement for better farming all along the lines, and to encourage the boy to get an education in agriculture and to remain on the farm.

The work in Alabama has been in progress scarcely a year and the results are very encouraging indeed. At present the work has been started in about 17 counties in the state. There is a total of approximately 2,000 boys listed in the work. There have been raised locally among merchants, bankers, and other public-spirited people over $\$ 2,000$ in prizes. In addition to this the state fairs in Birmingham and Montgomery are offering a total of about $\$ 500$ for the boys in the corn clubs. After making these exhibits at the state fairs the best of these will be carried to the National Corn Show.

It has been my pleasure during the last month to hold boys' meetings in several counties and to visit a large number of individual acres of corn. The yield in a great many cases is very remarkable. For example, one boy's acre of corn will yield at least 65 bushels of corn; and in addition to the corn there will be enough snap beans and corn middles to pay all the expenses for making the corn, including rent of land and interest on investment. I quote below from a letter recently received from a gentleman who lives in a community where a club has been organized: "Some of the boys are going to make 75 and 85 bushels per acre, and some are going to make as much as roo bushels." Another letter from a business man will give some idea as to how the business men regard the work: "I think the Boys' Corn Club has worked wonders in the cultivation of corn in this state. I have never seen as much enthusiasm among the old farmers as now prevails, and I feel certain that the Boys' Corn Club is largely responsible for it."

At a meeting held in northern Alabama I asked some of the boys to give me an idea as to the outlook of their corn crop. One, in making a report of his work, said: "Every farmer in a radius of two miles of my acre has visited my corn and said, 'If you make 35 bushels of corn on this acre we are going to follow your method.' " Prospects were good for a yield of more than 50 bushels on this acre. The father of this boy said, 
"I have a special acre myself and do not propose to have my boy beat me raising corn."

This movement is not a question of adding new duties to the county superintendent and teachers without additional pay, but a question of opportunity and service. No movement has yet been projected where superintendents of education and teachers may be of greater service to the people than in the organization of the Farm-Life clubs. This plan also furnishes the best method yet devised of bringing together in harmonious co-operation all the interests looking to better education and better farming. In this work the county superintendents, the teachers, the merchants, the newspapers, the State College of Agriculture, the State Department of Agriculture, and the State Department of Education can all work together for the common good.4

Another important phase of the agricultural-club idea is being developed by the Farmers' Institute Specialist of the Office of Experiment Stations of the United States Department of Agriculture. It is known as Farmers' Institutes for Young People. The following statement in regard to these institutes will indicate the object and character of the work undertaken:

In order, therefore, that opportunity to become acquainted with agricultural operations may be given to those who have left the public school and from whose ranks the future farmers and their wives must be supplied, the farmers' institutes in several states have organized and are now conducting what is known as "institutes for young people." The majority of these are not institutes in the sense in which the work of the farmers' institute has come to be defined. They are in reality boys' and girls' clubs conducted in the same manner as those operated by the public schools. . . . .

Because of the fundamental difficulty in securing teachers capable of giving vocational training and instruction in agriculture in the rural schools, and from the fact that after the scholars leave school no provision has been made for giving them the opportunity to receive such instruction, the farmers' institute has undertaken the training in agriculture of rural children after leaving school. In doing this it has found it necessary to drop from its system of instruction the purely educational feature and to devote itself strictly to giving vocational instruction. Such studies and practice, therefore, as the institute utilizes have in view the perfecting of the individual in his vocation. The institute system, therefore, partakes more nearly than any other of the trade-school method, and is intended for youths

- From a letter written by L. N. Duncan, U.S. demonstrator for Alabama, and professor of school agriculture, Alabama State Agricultural College. 
above 14 years of age. It will become the connecting link between the agricultural-club movement on the one hand and the regular farmers' institutes for adults on the other (I43).

In 1909, 20 states and territories are reported to have held institutes for young people. This system seems to be the best organized in Indiana, where about one-third of the counties have such institutes with an enrolment of over 12,000. The young people's institutes are held at the same time as the farmers' institutes but in separate sessions. The public is interested as indicated by liberal contributions, one county appropriating, in $1909, \$ 1,000$ for this work.

The extension department of the Kansas State Agricultural College is just introducing a correspondence school in connection with its young people's extension work. The object of this is similar to that of the young people's institute, being designed to help boys and girls who have been compelled to leave school.

The boys' clubs of Kansas, whose work thus far has been almost wholly confined to corn contests, are now being organized on a somewhat different basis. The plan follows that of the Boy Scouts of America and the clubs are known as the "Rural-Life Scouts." Although just started, considerable interest is being shown in these clubs. The leaders are generally principals of village schools or pastors of village churches. In counties where there is a Y.M.C.A. secretary, the organizations are affiliated with the Y.M.C.A. work.

The county superintendent of education and his teachers have been an important factor in making boys' clubs a success, whether under the auspices of the Government Demonstration Work, state agricultural colleges, or state departments of education. The work in large units, state or sectional, is really made possible by successful work carried out by county superintendents of schools or teachers in the various parts of the country. It may be of interest at this point to give somewhat in detail a concrete example of how a county superintendent of education 
went about organizing successful boys' agricultural clubs in his own county.

The county superintendent of Delaware County, Iowa, began to organize boys' clubs six years ago, holding township meetings where the boys brought corn selected from their fathers' seed corn. The meetings were addressed by an expert, on "What Constitutes Good Seed Corn." This was accompanied by demonstrations from samples of poor and good ears. The corn brought by the boys was then judged and commented upon by the expert. The superintendent then distributed seed corn which he had bought for this purpose. The year following the boys came together in a contest showing the results obtained from the corn distributed the year before. This work was continued through the next year, except that the boys selected their own seed corn from their fathers' corn. A short course in agriculture was held at Manchester, the county seat, which about sixty boys attended. The corn clubs continued to grow in interest from year to year until most of the boys were as good as, or even better judges of corn than, their fathers. Last year the work was varied by using oats instead of corn. The superintendent purchased forty bushels of Canadian oats, and distributed the seed among the boys of the county. At the close of the season a contest was held at which the results of the season's work were shown. The experiment was watched with much interest throughout the county, and the farmers were eager to purchase seed from the boys for their own farms. In one year the value of Canadian oats for Delaware County was demonstrated by the boys, and oat production in the county was greatly improved.

All this was extra school work, but the superintendent made good use of the interest thus aroused to help and improve the regular school work. Raising corn and oats became subjects of compositions, references to bulletins and books were used as reading lessons, and estimates of cost and yield furnished material for arithmetic. By means of printed instructions sent to teachers from time to time, the formal work of the schools became enlivened and strengthened by its practical application. 
The work in Delaware County is a typical example of how the education of a county or township system may be redirected by means of boys' clubs. Springfield Township, Ohio (I42), Keokuk (6I) and Page (I44) counties, Iowa, Natchitoches Parish, Louisiana, Winnebago County, Illinois (145, I46), Wexford County, Michigan, and many other places might be mentioned where boys' agricultural clubs have not only been the means of improving school conditions but by their success have led to similar work being introduced in other places.

Although not connected in any way with the public schools, the work of W. B. Otwell, editor of the Otwell's Farmer Boy, Carlinville, Ill., deserves special mention. Mr. Otwell is chiefly responsible for the beginning of the state-wide development of boys' corn clubs in Illinois, and had charge of their exhibit at the St. Louis Exposition, where I,250 boys' exhibits received awards. By means of his paper he is interesting a large number of boys of the Middle West. He conducted in I9Io a corn contest in which 25,000 boys were competing. ${ }^{5}$ Another feature of his boys' club is an annual encampment for those who can attend, for the purpose of agricultural study.

In order to give description in sufficient detail, the foregoing discussion of boys' agricultural clubs has been limited to a few typical examples of what is now actually being accomplished. References have been made from time to time to the public interest in the clubs and to their influence upon the public schools.

It was the intention in preparation of this chapter to include a fuller discussion of the relation of this movement to rural education than space will permit. Opinions have been gathered from a number of state superintendents, and from others interested in rural education as to the reaction of the agricultural club movement upon the rural schools. These opinions are well summed up in the following:

Keeps boys in school longer; gives teacher greater influence and power; convinces farmers that school people want to and can be useful to the

sOtwell's Farmer Boy, Carlinville, Ill., December, Igro. 


\section{II4 AGRICULTURAL EDUCATION IN PUBLIC SCHOOLS}

farming interests, and tends to make the school the center of community life; stirs farmers to greater endeavor and to better methods of farming, and increases general interest in agriculture and returns.

Perhaps the most important contribution that these clubs are now making to agricultural education in the public schools is the recognition by the patrons of the direct value in dollars and cents that such instruction has, a recognition which will lead to better support of the schools by the community and greater interest in them. 


\section{CHAPTER XIII}

\section{ELEMENTARY AND SECONDARY SCHOOLS}

One of the most important recent tendencies in education is the redirection of schools of a community in terms of the daily welfare of its people. For a rural community such redirection must be largely in terms of agriculture and of other country-. life interests. It is for this reason that so much emphasis is placed upon agriculture as a means of increasing the efficiency of rural schools.

When this idea began to express itself in practice in rural communities the elementary school was the first to receive attention. But age of pupils, many grades in one room, lack of properly qualified teachers, and various other limitations have led many to doubt the wisdom of this selection. The results of introducing agriculture as a school subject into the elementary schools have thus far not been entirely satisfactory. Nevertheless adjustments are taking place, so that agriculture, not as a systematized subject of instruction but in certain of its naturestudy aspects, will no doubt find an important place. About all that may reasonably be expected of agriculture in the elementary schools is to interest the children in country-life subjects so that they may know the common birds, insects, trees, weeds; the meaning of some of the best farm practices, such as selecting and testing seed, how the soil holds water and means of preventing its loss, care of milk and value of its fat content, etc.; and through such studies to lead the children to appreciate the fact that there is something worth while in the immediate world in which they live.

The rural high school is now being recognized as the best place below the college for instruction in agriculture. Such a high school is closely related to rural education in two ways: one in the adjustment of its own work to the industrial and 
social needs of its community, the other in giving its graduates who expect to teach in rural elementary schools some preparation for teaching country-life subjects.

\section{ELEMENTARY SCHOOLS}

The introduction of agricultural subjects into elementary schools has proceeded mainly along two lines-one as a result of legislation, the other as a natural outgrowth of boys' agricultural clubs.

In many places in states where agriculture is a required subject for instruction in rural schools no such legislation was really needed, for the subject was already being introduced in a sane and effective way, and was being made use of as far as the experience of the teacher and conditions of the school environment would permit.

The results of compulsory teaching of agriculture in the elementary schools have been twofold: first, in stimulating those in charge of the administration to provide helps to those teachers who are expected to carry out the provisions of the law; second, in the production and use of textbooks on elementary agriculture. The first has been done through bulletins, teachers' leaflets, institute instruction, summer normal schools, and in various other ways. Some agricultural colleges have been called upon to give attention to elementary education sooner than they otherwise would. They have been forced to study the rural-school situation and devise means for improving it. The work of state offices of education and of agricultural colleges in promoting agricultural education in rural communities has already been considered somewhat in detail in previous chapters. But the contributions of these two agencies to agricultural education in elementary schools must not be ascribed wholly to legislation, for in several states having no requirements as to teaching of agriculture both state departments of education and agricultural colleges have done excellent service in providing helps for teachers wishing to introduce the subject in their schools. 
The second result has been less satisfactory. Indeed, in some instances it has proved a positive detriment to agricultural education. It has in effect added another textbook subject to an already crowded rural-school curriculum, for many teachers, in spite of whatever suggestions they may receive from leaflets or institute instruction, know of no other way to teach except by means of a textbook. It has put undue emphasis on the agricultural textbook. More than a score of elementary textbooks have appeared within a decade. Publishers have been very active in securing the use of their books in the rural schools. While the value of a good textbook must be conceded, it is apt to be the means of substituting agricultural information for real agricultural instruction. The kind of agricultural instruction best adapted for the elementary schools cannot be given merely by means of recitations from a textbook.

There may be some justification in making the teaching of a subject compulsory on the ground that otherwise it would never be taught. On the other hand it may seriously be questioned, since the whole burden of such a measure falls upon the teachers, whether efficient teaching of any subject may be secured by mandatory legislation. The length of teaching service of the average rural teacher is very short, perhaps less than three years. As a result rural teachers are constantly being recruited from the young graduates of grammar and high schools. It is claimed by some that whatever preparation these inexperienced teachers may make is largely determined by what they are expected to teach. If they must teach agriculture they will make some effort to prepare themselves to teach this subject. It is probably on this theory that so many states have tried this plan of introducing agriculture into the rural schools. At least sixteen states have tried this plan, and in several other states bills providing for such instruction were considered by legislatures last in session, and one (in Ohio) became a law.

The second line of development of agricultural education 
in elementary schools has produced a much better type of instruction than the former or mandatory method. This is partly because the results of boys' clubs have shown the value of agriculture as a school subject, and have thus secured for it public approval and support, and partly because experience in managing these clubs has given the teachers some insight into methods of adapting the subject to the needs of the school, and of making it an effective part of the regular school work.

Teachers who have been the most successful are those who have selected agricultural subjects of special interest to the school community, and who have used methods calling for selfactivity on the part of the pupils-having the pupils learn by doing rather than by reciting. The following is a list of various kinds of work reported to be successfully adapted to rural schools (I47): experimental plots for plant breeding, soil inoculation, and other soil experiments; ear-to-row method of improving corn, and use of acre plots; seed germinating including tests of viability; collection of economic plants, weeds, weedseed, and insects; budding, grafting, pruning, and spraying fruit trees; milk testing with Babcock milk tester.

The importance attached by pupils and patrons to such work is well illustrated by the following report. In one county in Iowa it is the practice for each school to have in the spring a germinating test for corn. One teacher says of this work:

$\mathrm{My}$ boys who would not go across the road for a song book went two miles in the snow to get some sawdust for a germinating box. When the corn had germinated, the farmers came to the schoolhouse to see how their corn had turned out, and incidentally saw the work of the school. Why, farmers came who couldn't remember when they had been inside the schoolhouse before! (148, p. 18).

The rural school is badly in need of redirection, but it will take more than the teaching of agriculture to bring this about. However, some sort of nature-study agriculture that has elements of interest to pupils and parents alike may do much toward putting the rural school in the way of redirection. Here and there are promises of the fulfilment of L. H. Bailey's vi- 
sion of a rural school living up to its possibilities. Referring to the kind of agricultural studies suggested in the above report, he says:

All such teaching as this will call for a new purpose in the school building. The present country-school building is a structure in which children sit to study books and recite from them. It should also be a place in which the children can work with their hands. Every school building should have a laboratory room, in which there may be a few plants growing in the windows, and perhaps an aquarium and terrarium. Here the children will bring flowers and insects and samples of soil, and varieties of corn or cotton in their season, and other objects that interest them, and here they may perform their simple work with tools. Even if the teacher cannot teach these subjects, the room itself will teach. The mere bringing of such objects would have a tremendous influence on children: patrons would ask what the room is for; in time a teacher would be found who could handle the subject pedagogically. Now we see children carrying only books to school; some day they will also carry twigs and potatoes and animals and tools and contrivances and other personal objects (122).

\section{SECONDARY SCHOOLS}

Previous to 1906 there were but few high schools (excepting agricultural high schools) giving instruction in agriculture; in $1906-7$ there were $75-80$; in $1907-8,240-50$; in $1908-9$, over 500; in I909-10, probably 1,000 ; in I9IO-II, incomplete data indicate as many as $\mathrm{x}, 500$. The number of agricultural high schools (those giving two or more years of agricultural instruction) in 1909 was 125 ; in I910, I44. Of these there were receiving local support, in 1909,24 ; in 1910,33 ; receiving state aid in 1909, 29; in I910, 39; technical schools giving agricultural instruction in 1909, 37; in 1910, 47 ; connected with agricultural colleges in 1909, 34 ; in I9IO, 35 ( 149 , pp. 333-35; I 50, pp. 23-25).

Secondary agricultural education has developed along several lines, giving rise to as many as eight more or less distinct types, viz. (a) agricultural-college, (b) district, (c) county, $(d)$ village-township, $(e)$ city, $(f)$ state aid, $(g)$ technical, $(h)$ normal. ${ }^{1}$

'The first four types of this classification are suggested by G. A. Bricker in his Teaching of Agricultural in the High School, chap. ii (151). 
The agricultural-college type is well illustrated by the School of Agriculture of the University of Minnesota. This school has the distinction of being one of the first secondary schools of agriculture. It was

organized in 1888 with the object of giving practical education to young men and women who are unable to pursue the full college course in agriculture. It offers a practical course of study designed to fit young men and women for successful farm life, and aims to give its students the necessary preparation for useful citizenship (I 52, p. 8).

The district type is found in Alabama, Arkansas, Georgia, Oklahoma, and Virginia. The districts in each of these states except Oklahoma correspond to the several congressional districts. The objects of all these schools are similar and are summed up in the following statement concerning the Alabama District Agricultural Schools which were the first of this type of schools to be established:

To turn out young men well grounded in the underlying principles of scientific and practical agricuiture, that they may make successful planters and advance the farming interests of the state.

To give such instruction and training as will fix in the minds of the young men high ideals of country-life education, as is done in the best agricultural high schools under the name of "agriculture and home economics."

To educate and fully equip young men and women for efficient teaching in the public schools of the state.

To prepare those who desire to enter higher institutions of learning $\left(153\right.$, p. 15). ${ }^{2}$

The establishment of county agricultural high schools is now authorized in at least twenty-three states. In many of these states such schools receive state aid. The county schools of Wisconsin are the oldest and best known. In the Wisconsin schools

the courses are two years in length and include subjects of general agriculture; biology and physical subjects; laboratory and field and shop work; domestic science, home economy, and hygiene; sewing and millinery; farm management and accounts, besides courses in English, history, civics, and other branches of the usual high-school type (15I, p. 23).

- See Georgia Districl Agricullural Schools (154). 
The Baltimore County (Md.) Agricultural High School presents some features that deserve special mention:

The school is meant especially to meet the needs of a rural community. It presents all the usual subjects taught in high schools, except foreign languages, and in addition teaches agriculture, domestic science, and manual training. It is thus planned that students graduating from this school will, in addition to a good general or academic education, have some industrial or vocational training to fit them to take their places in the world (I 55, p. I). The principal, who is a specialist in agriculture. devotes the entire year to the school, spending the usual summer vacation in the interests of the school, inspecting and directing the work of the pupils who are carrying out in a practical way experiments and problems outlined during the school year. In this manner the principles of agriculture taught in the school are carried over into practice under normal farming conditions. In addition to offering excellent instruction in agriculture and in other subjects, the school further serves the community by giving courses for rural school teachers and for farmers and their wives, and by furnishing a center for religious service and literary and social activities for the young people ( 156$)$.

Most of the high schools giving instruction in agriculture are of the village-township type. The work of two of these high schools which were among the first to make agriculture a subject of instruction has already been referred to in chap. vii. The motive for reorganizing rural village and township high schools on the basis of country-life interests is well expressed in an account of the New Holland (Ohio) High School:

The larger percentage of the boys and girls who are enrolled in the village and township high schools of this state will spend their lives either in the rural districts or villages where farm life and agricultural industries are the leading interests. They will be either farmers or farmers' wives, or they will be engaged in business very intimately connected with agriculture. In view of this condition the Board of Education at New Holland, Ohio, has placed agriculture in the curriculum of the high school ( $157, \mathrm{p} .3$ ).

Another of the earlier schools of this type whose success has attracted considerable attention is the John Swaney School, Putnam County, Illinois ( $5^{8}$ ). 
High schools of cities surrounded by agricultural communities enrol a large number of pupils from the country. The special needs of such pupils have recently been recognized by a few city high schools. Thus in the Stockton (Cal.) High School a department of agriculture was organized at the beginning of the present school year. A director who is an agriculturalcollege graduate, has charge. $\mathrm{He}$ is not expected to teach more than one-third of his time; the rest of his time is to be devoted to the "study of agricultural problems at first hand throughout the farm'area tributary to Stockton." He is to take up any agricultural problem at any time, go to the farm, and help find a solution. By this means the farmer is reached directly and made to feel that our school director and teachers are willing and able to educate boys and girls for profitable farm life and to cope with economic problems troublesome and burdensome to them. Short courses are also offered to farmers and those interested in agriculture who cannot take the full course. A course is offered to students who expect to be teachers with a view of providing the rural schools with teachers having a knowledge of, and an interest in, farm life. Further aid is given the rural schools by a series of teachers' meetings and conferences with the director in charge (I59).

The Gardena High School of Los Angeles has been offering courses in agriculture with particular reference to horticulture, gardening, and poultry raising which are the dominant interests of the community (I60). The San Diego (Cal.) High School has also recently established a department of agriculture somewhat after the Stockton plan.

Agriculture in city high schools located in farming regions offers a very promising field for further development. These schools have advantages that compensate somewhat for their immediate non-rural surroundings. Their laboratory facilities are usually very good, and they are able by means of high salaries to secure experienced and well-equipped teachers.

In order to encourage the introduction of agriculture into 
rural high schools some states have offered the inducement of state aid to a limited number of schools undertaking this work. For example, Minnesota is now giving for this purpose $\$ 2,500$ to each of thirty high schools, and $\$ 1,000$ to each of sixty. This method has some advantages over entire local support, for it not only makes possible the securing of good teachers but provides for a higher standard of efficiency than is likely to be secured by a purely local management. (See chaps. iii. and iv.)

The Hinckley State High School which is a good example of this type of high school organized in Minnesota offers the following courses: literary course, four years; agriculturalindustrial course, four years; special agricultural course, two years; short course for institutes for farmers; normal course for rural teachers, one year (I6I).

A somewhat different plan of state aid to high schools giving instruction in agriculture, mechanic arts, and home-making is being worked out in New York. The following extract from the educational law of I9Io will indicate the scope of the New York plan:

The Commissioner of Education in the annual apportionment of the state school moneys shall apportion therefrom to each city and union free school district the sum of $\$ 500$ for each independently organized general industrial school, trade school, or school of agriculture, mechanic arts, and home-making, maintained therein for 38 weeks during the school year and employing one teacher whose work is devoted exclusively to such school, and having an enrolment of at least 25 pupils, and maintaining a course of study approved by him. The Commissioner shall also make an additional appropriation to each city or union free school district of $\$ 200$ for each additional teacher employed exclusively in such schools for 38 weeks during the school year (I62, p. 3).

In order to secure successful operation of this law, the organization and general oversight of all schools receiving state aid for teaching agriculture are under the direction of the State Department of Agricultural Education. The State Department of Education has also prepared a very complete series of syllabi of courses in agriculture for high schools. From this series it is 
possible for a school to select subjects adapted to the particular agricultural interests of the community (163).

Agriculture in the technical type of secondary schools receives much the same attention as in the district type, the chief difference being that the latter offers no courses in mechanic arts. These schools seem to be patterned after state agricultural and mechanical colleges, but offering only instruction of secondary grade. A good example of this type is the California Polytechnic School, which was opened in 1903 at San Luis Obispo. This institution is supported by the state, and is intended "to furnish to the young people of both sexes mental and manual training in arts and sciences, including agriculture, mechanical engineering, business methods, domestic economy, and such other branches as will fit students for non-professional walks of life" (16, p. 22).

Agricultural education in State Normal Schools has already been discussed in chap. vi. Instruction in agriculture in these schools is usually of secondary grade but with the special aim of preparing teachers. In some of these schools considerable emphasis is placed upon agriculture, and work corresponding to some of the best agricultural high schools is offered. For example, the Cape Girarcleau (Mo.) State Normal School has a department of agriculture not only for teachers but for furnishing "young men from the farm an opportunity of obtaining the equivalent of a good high-school education of such a nature as will fit them to carry on the business of farming according to the most approved farm methods" ( 164, p. 63).

The development of secondary agricultural instruction has proceeded along two lines, one by employing existing high schools, the other in organizing separate agricultural high schools. The recent tendency as indicated by the statistical summary introducing this discussion seems strongly in the direction of the former. No doubt there is much to be said in favor of separate agricultural high schools to meet conditions in certain localities, but taking the country as a whole the natural tendency, as above indicated, of maintaining the unity of our present 
school organization presents obvious advantages which the public has already begun to realize.

Attention should be given, in this connection, to the fact that much misapprehension and undue concern exists as to the plan of organization of the agricultural high school. A careful analysis of the course of study of the average agricultural high school will show less divergence from the plan of the ordinary high school than many suppose. It will be found that the courses of study are essentially the same in many particulars, the chief difference being the substitution of agricultural and household-arts subjects for the foreign languages, with perhaps more emphasis on the practical side of the sciences and less emphasis on certain phases of mathematics ( 165 ).

One real difficulty in making the most of agriculture as a school subject lies in the fact that there is little opportunity for agricultural practice corresponding to shop practice in mechanic arts. The most active season of agricultural work is during the summer vacation. This difficulty may be met in the way already referred to in the account of the Baltimore County (Md.) Agricultural High School, where the teacher of agriculture devotes the usual summer vacation period to looking after experiments being conducted by the pupils. This matter has been carefully studied by a special agent of the Massachusetts State Board of Education and conclusions submitted to the legislature in the form of a Report of the Board of Education on Agricultural Education (166). Provision for proper farm practice as recommended in this report is secured by part-time work in agriculture which may utilize "home land, equipment, and time, outside school hours, for practical training supervised by the school." The scheme is worked out in considerable detail by means of concrete examples of various "farming projects" that may be undertaken. Among the major projects suggested are caring for a kitchen garden, keeping a pen of poultry, caring for a selected part of an orchard, raising a specified crop of potatoes, caring for one cow. Each major project is broken up into minor projects. For example, keeping 
a pen of poultry would include as minor projects building a poultry house according to plans and specifications worked out at school. This in turn is divided into such subordinate minor projects as are necessary for successful completion, such as selecting a site for the house, taking into consideration: soil as related to poultry culture, underdrainage, conditions of sunlight and shade, convenience of access, etc. The legislation proposed by this report was passed by the legislature last in session. When the proposed plan goes into effect, its results should be carefully studied by all who are interested in secondary agricultural education.

The rapid introduction of agriculture into high schools is responsible, in part at least, for two interesting educational reactions. One is the changed attitude of colleges toward agriculture as an entrance unit. A few years ago most colleges refused to give any credit for work done in this subject in high schools. Now 36 colleges actually recognize the subject and 27 express a willingness to do so when it is offered as an entrance unit, and several other colleges are considering the matter (x67).

The other reaction is upon the method of presenting secondary science. There is now a growing tendency to relate science instruction more and more to the practical affairs of life (r68). Recent experiments seem to justify this method of approach to a science even when judged from the point of view of pure science ( 169, I 70).

Agricultural colleges are now well established, and their problems are largely matters of detail and of research. The problems of agricultural education are now being shifted to the secondary schools offering agricultural instruction. There is a great diversity, not only in respect to types of schools, but also as to methods, time devoted to the subject, equipment, qualification of teachers, and in other respects. But of the widespread interest there can be no doubt. The results on the whole promise much for the development of rural education and redirection of rural schools. 


\section{CHAPTER XIV}

\section{TEXTBOOKS}

One striking evidence of the growing interest in agricultural education in elementary and secondary schools is the number of textbooks on agriculture that have appeared in recent years. ${ }^{1}$ Of the seventy-five or more textbooks on this subject nearly forty have been published since 1900 .

An excellent account of the textbooks of agriculture, including historical aspects, was written by L. H. Bailey in 1903 (I7I). The present discussion will therefore be confined chiefly to the textbooks published since 1903. In this period of seven years at least twenty-eight textbooks of various kinds have been written. Emphasis should be put on various, for the diversity of plan and treatment of the subject in these books makes it difficult to find a basis of classification. They will be considered in this discussion as three types: for elementary schools, for secondary schools, and for teachers.

Most elementary textbooks are informational in character. The subject is generally presented in clear and simple language easily within the grasp of the pupil. It is assumed that the pupil has had sufficient concrete experiences with agricultural matters, and that the text will help him to interpret these experiences. There is a minimum of effort required of the pupil to find out things for himself. Questions are often given at the end of each chapter, but they are usually merely a summary

IIt is possible that this statement should be qualified, for the number of books published does not indicate the number in actual use. A quotation from a private letter written by the editor of one of the largest publishing companies of agricultural books is significant: "Outside of one textbook published by a Boston house, I do not believe there is another manual of agriculture or agricultural textbook that has paid the publishers anything beyond mere cost, and some have not even paid cost." This was written in r909. Since then conditions may have changed for there has been a great development of interest in the subject. Besides, fourteen books have been written during and since rgog. It seems likely that the small demand for certain textbooks may be due to the quality of the books themselves. 
of the text, and test the memory rather than ability to interpret. Sometimes experiments are introduced, either in the text or at the end of chapters. But conclusions to be drawn from these experiments are either so implied in the text or are so obvious that the suggested experiments become merely concrete examples or illustrations of discussion in the text. Books of this kind are easily adapted to the prevailing recitation method and consequently are in extensive use ( 172 ). Several books have appeared in which the experiment predominates. Here problems and some suggestions as to procedure are given. The pupil is expected to find answers by means of his own investigations. $\mathrm{He}$ is supposed to learn to find out things for himself. However, even in otherwise admirable books, induction is often "ready-made for the pupil" (I73). This method of teaching by means of experiment does not fit in very well with prevailing methods of teaching. Many of the teachers themselves have not had the benefit of laboratory training, and hence know very little of any other than the textbook method of learning or teaching.

Another kind is the one in which agriculture is correlated with arithmetic. Problems for demonstration of the various arithmetical principles relate to agricultural affairs. In the preface of one book occurs the statement, "The pupil will unconsciously absorb and retain many valuable facts and principles relating to agricultural practice"; in the preface of another, the statement, "We trust that this little book, by combining the subjects of arithmetic and agriculture, will be of material assistance to teachers in their efforts to do effective work in both branches" (177, 193).

Perhaps one reason for the number of elementary agricultural textbooks lies in the nature of the subject itself.

Considered as an industry, agriculture is manufacturing, buying, and selling. It is business. But unlike most other businesses, the operator is producer of the raw material as well as dealer in the products. In order to produce his wares to the best advantage he must know much of the principles in accordance with which the most successful production must proceed. 
In other words, he must know much of the sciences on which agriculture is based, as physics, chemistry, botany, and other sciences. But he should never forget that the practice of agriculture is an art and not a science.

These remarks will suggest why it is that there is such a bewildering diversity in plan in the various textbooks of agriculture. One reason why these textbooks have not been more successful in accomplishing the missions for which they are designed is the fact that they look upon agriculture from the academic point of view rather than from the agricultural. Another reason is the attempt to make them "practical" by inserting specific directions for the performing of accustomed farm operations; for these directions must necessarily be of local and temporary application, whereas principles are general and abiding (I I I, p. 690).

Considered from the standpoint of scientific accuracy most of these textbooks are good, but in some there are inaccurate data, or statements at variance with well-established facts. Considered from the standpoint of pedagogy most of these texts are lacking. The matter is often presented with little or no reference to this important aspect of a textbook. Indeed, some are barely more than abridged encyclopedias of agricultural information. This general defect may possibly be accounted for when we consider the fact that the authors of all these books, with a few exceptions, are college professors, whose chief interest is in the subject-matter with apparently little interest in organizing material from a teaching standpoint, and giving no recognition to the social possibilities of their subject.

It is probable that the most useful book, at least for the present, will be one that attempts at the same time to awaken an interest in country life and to set the pupil at the working out of specific problems. Mere problems are too "dry" to attract pupils, except now and then under the inspiration of an extra good teacher. On the other hand, mere information-giving has little teaching value and is not likely to arouse any important enthusiasm for the open country and the farm. On account of the diversity of interests to be served, no single textbook of agriculture can hope to have great leadership in all parts of the country. The thoroughly satisfactory text is apparently yet to be written (122).

The purpose of an agricultural textbook for secondary schools is well expressed in the preface of a recent book of this grade: "to make the teaching of agriculture in existing high 
schools comparable in extent and thoroughness with the teaching of physics, mathematics, history, and literature." Although some of the elementary textbooks already referred to are being used to some extent in high schools there are only five books known to the writer that measure up to the standard just quoted. No two of these follow the same plan of treatment. In one laboratory work largely predominates; in another good laboratory exercises follow each chapter; in another some experiments are suggested in the text and among the questions at the end of the chapters; in two no laboratory exercises are suggested except in a general way in the text ( $176,190,195,197$, 200). These are all well written, and where one is used as a textbook the others could be used to advantage as reference books. For a detailed comparison of these textbooks the bibliography should be consulted.

There are three other books which properly belong among secondary textbooks of agriculture but which do not cover the entire subject. "There are those who believe that when agriculture is fully introduced as a secondary subject, it will consist, as in college, not of one but of several courses, each with its distinct and separate text." One of these is a laboratory manual dealing with soils and crops (I98); the other two are textbooks, one dealing with fertility of the soil, the other with plant and animal improvement (184, 196).

A third type includes books for teachers. These books deal with the subject from the standpoint of teaching. Five are for teachers in elementary schools (185, I87, I89, I94, I99), and one is for teachers in secondary schools (I $5 \mathrm{I}$ ). Not much attention has yet been given to the teaching problems of the subject of agriculture, but they are quite as important as the subject-matter.

Referring to elementary agricultural textbooks, L. H. Bailey says: "Efforts enough have been made, but they have fallen short of anticipations. Before textbooks we need teachers; and we must appeal to the child through his interest in nature 
rather than technically in the farm" (I7I, p. 696). Elementary textbooks are not nearly so important as elementary teachers. It is to the new teachers who are to have at least a high-school education that we must look to carry agricultural education into the rural elementary schools. It is for this reason that additional importance is to be attached to instruction in agriculture and country-life subjects in rural high schools. A good textbook with well-selected experiments, although alone not suffcient, is, nevertheless, quite essential to any general introduction and efficient instruction in these high schools.

As this discussion of textbooks of agriculture is really supplementary to one already made by L. H. Bailey (I 7I), his plan of chronological bibliography, with annotations as to contents, will be followed. His article and this chapter, including references $I_{5} \mathrm{I}$ and $\mathrm{I}_{72--202}$, inclusive, will thus bring the subject up to date. 


\section{BIBLIOGRAPHY}

\section{WITH ANNOTATIONS}

The titles are arranged in order of citation in the various chapters of the text, except numbers 174 to 202 . These are arranged in chronological order as in L. H. Bailey's bibliography in his Development of the Textbook of Agriculture in North America (17I), the two lists making an almost complete bibliography of North American textbooks of agriculture up to the present.

The bibliography has been selected with the view of presenting typical contributions on various phases of agricultural education in elementary and secondary schools. No attempt has been made to make it complete.

I. Agricultural Education. Chardes W. Dabney. "Butler's Monographs in Education" (I904), II, No. I2.

A historical summary of agricultural education in the United States.

2. Historical Sketch of the U.S. Department of Agriculture: Its Objects and Present Organization. Charles H. Greathouse. U.S. Department of Agriculture, Division of Publications, Bul. 3, second revision (1907), 97.

The first part (pp. 5-57) deals with early government aids to agriculture, agricultural division of patent office, organization of the independent department, the department raised to first rank, buildings, bureaus, divisions, and offices. The second part gives an account of legislation and a tabulation of expenditures.

3. Secondary Courses in Agriculture (seventh report of the Committee on Instruction in Agriculture). U.S. Department of Agriculture, Office of Experiment Stations, Cir. 49, Io.

A number of high-school courses are given with suggested changes adapting them to the introduction of agriculture.

4. A Secondary Course in Agronomy (eleventh report of the Comnittee on Instruction in Agriculture). U.S. Department of Agriculture, Office of Experiment Stations, Cir. $77,43$.

This report contains a syllabus of agronomy, instructions to teachers and 113 lectures, recitations, demonstrations, and laboratory exercises on various phases of agronomy. The plan is a good one to work to, but is somewhat in advance of, or too advanced for, the average high school.

5. The Teaching of Agriculture in the Rural Common Schools (ninth report of the Committee on Instruction in Agriculture). U.S. Department of Agriculture, Office of Experiment Stations, Cir. 60, 20.

This report discussed the development of industrial training in the common schools and gives an oulline of wark in nature-study, and elementary agriculture for such schools. 
6. Publications for free distribution (revised annually), U.S. Department of Agriculture, Division of Publications, Cir. 2 (Ig08), 76.

This list of publications and copies of all publications which it mentions will be sent free on application to the Secretary of Agriculture, Washington, D.C.

7. Free Publications of the Department of Agriculture Classified for the Use of Teachers. D. J. Crosby and F. W. HowE. U.S. Department of Agriculture, Office of Experiment Stations, Cir. 94 (I910), 35.

This contains a list of "free publications classified for use of teachers of agriculture, botany, chemistry, domestic science, and hygiene, geography, physics, physiology, and zoölogy, including entomology."

8. Publications for sale (revised annually), U.S. Department of Agriculture, Division of Publications, Cir. 3 (1908), 99.

This list may be obtained in the same way as (5) but applications for publications mentioned in this list must be addressed to the Superintendent of Documents, Government Printing Office, Washington, D. C. Only coin or currency should be sent, as stamps are not accepted.

9. Monthly list of publications, U.S. Department of Agriculture, Division of Publications, Monthly Circular, 4.

This circular will be sent regularly to all who apply for it. Address, Secretary of Agriculture, Washington, D.C. The list contains titles of all new publications, including reprints and revisions, of the Department.

Iо. The Weather Bureau and the Public Schools. JoHn R. WEeks. Reprint from Yearbook of Department of Agriculture for 1907, 267-76.

This reprint contains a discussion of methods of teaching, an outline by grades of meteorology for the elementary schools of the state of New York, the purpose and value of meteorology in school work, weather map and other aids to teachers, home-made apparatus, lantern slides.

II. Forestry in the Public Schools. Hugo A. Winkenwerder. U.S. Department of Agriculture, Forest Service, Cir. I30 (I907), 20.

This circular suggests how various school subjects may be correlated with forestry and gives an outline for such correlation with each subject. It also contains a very complete classified list of references.

12. Forest Nurseries for Schools, U.S. Department of Agriculture, Farmers' Bul. 423 (1910), 24.

Directions are given in detail for establishing a forest nursery in connection with an average public school.

13. The School Garden. L. C. CoRBETt. U.S. Department of Agriculture, Bureau of Plant Industry, Special Cir. (1905), 6.

Brief plans are given for a school garden. Six common vegetables and six common flowering plants are described with cultural directions.

14. The School Garden. L. C. CoRBetT. U.S. Department of Agriculture, Farmers' Bul. 218 (1905), 40.

This bulletin discusses value of garden work, type of plants for garden, laboratory exercises, studies of soil, plants, roots, stems, leaves, cuttings, budding, window boxes, and decoration of school yard. 
15. Results of Boys' Demonstration Work in Corn Clubs in IgIo. S. A. KNAPP and O. P. Martin. U.S. Department of Agriculture, Bureau of Plant Industry, Doc. 647 (I9IO), 7 .

The origin of the boys' corn club work in connection with the farmers' demonstration work is traced back to 1906, and a brief review of the development of the movement since 1909 is given.

16. The American System of Agricultural Education. A. C. TRUE and D. J. Crosby. U.S. Department of Agriculture, Office of Experiment Stations, Cir. 83 (1909), 27.

Agricultural education in America is discussed briefly as follows: Departments of original research and graduate study in agriculture; agricultural colleges; secondary schools of agriculture; elementary schools; schools for Negroes and Indians. Under elementary instruction the work in different parts of the country includes, (I) nature-study with plants, farm crops, domestic animals, and soils; (2) school garden work, including improvement of school grounds; (3) lecture courses and institutes for rural school children; (4) organization of clubs among school children.

17. Experiment Station Record. E. W. Allen, editor. U.S. Department of Agriculture, Office of Experiment Stations.

The Record contains numerous abstracts of publications of the agricultural experiment stations and kindred institutions in this and other countries; articles and editorials on topics of special interest in agricultural science by American and foreign experts. One department is devoted entirely to reviews of publications on agricultural education. With the beginning of the current volume (XXI) this serial will be issued in two volumes a year of six numbers each. Subscription, one dollar per volume, payable in advance to the Superintendent of Documents, Government Printing Office, Washington, D.C.

18. Form of Organization for Movable Schools of Agriculture. John Hamrton. U.S. Department of Agriculture, Office of Experiment Stations, Cir. 79 (1908), 8.

A plan is proposed to organize movable schools of agriculture for farmers over nineteen years of age and for teachers in rural schools. A course is to extend over three or four seasons. The purpose is to equip several persons in each community "so that they will be able to improve in their locality the branch of agriculture which the school represents."

19. Education for Country Life. Willet M. Hayes. U.S. Department of Agriculture, Office of Experiment Stations, Cir. 84 (1909), 40.

This is a reprint of an address given before the Minnesota Educational Association, January 2, 1908 . It contains a general discussion of agricultural education, followed by plans for organization of schools for country life, county system of consolidated rural schools, or the farm school, the agricultural high school, and financing consolidated rural schools in Minnesota.

20. List of publications of the Office of Experiment Stations on agricultural education, U.S. Department of Agriculture, Office of Experiment Stations, Cir. Oct. 27, 1908, I3.

This comprises 136 publications: 24 circulars, 65 bulletins, 25 separates, 9 lectures, 3 documents. All phases of agricultural education from elementary to graduate instruction are represented. The following are 
some of the publications relating to elementary schools: Separates, Boys' Agricultural Clubs, Illustrative Material in Teaching Agriculture in Rural Schools, Training Courses for Teachers of Agriculture; Bulletins: 160, School Gardens, 186, Exercises in Elementary Agriculture-Plant Production, 195, Simple Exercises Illustrating Some Applications of Chemistry to Agriculture; Circular 52, Books and Bulletins on Nature-Study, School Gardening, and Elementary Agriculture.

21. "The Work of the Bureau of Education." U.S. Bureau of Education. Report of Commissioner ( 1907 ), I-36.

A short historical account is given, followed by purpose, publications, organization, agricultural and mechanical colleges, and appendix containing laws relating to Bureau, descriptions of facilities for research, education in Alaska, and statistics of maintenance of Bureau.

22. Development of Agricultural Education. Elmer Ellsworth Brown. U.S. Department of Agriculture, Office of Experiment Stations, Bulletin No. I96 (1907), 49-54.

An address given on the occasion of the fiftieth anniversary of the founding of. Michigan Agricultural College. The Commissioner discusses the relation agricultural education bears to general education.

23. "School Gardens." E. GANG. U.S. Bureau of Education. Report of Commissioner (1898-99), 1067-84.

This is one of the best short accounts, especially from historical standpoint, published. "Contents: Historical review; sites and arrangement of school gardens; different sections of school gardens; management; instruction in school gardens; educational and economic significance of school gardens."

24. "Methods of Instruction in Agriculture." U.S. Bureau of Education. Report of Commissioner (1897-98), I 575-1616.

This chapter contains reprints of several Cornell University and Purdue University leaflets, and a report of the work at Cornell University under the Nixon law of 1897 .

25. Agricultural Education, Including Nature-Study and School Gardens. James Ralph Jewell. U.S. Bureau of Education, Bul. 2 (1907, revised I909), I48.

The subject is discussed under six heads: Nature-Study, School Gardens, Elementary Agricultural Education, Agricultural Education, Practical Advantages of Agricultural Education. There is also a bibliography of r 34 titles, and appendices on nature observations in schools of Nova Scotia, and on the Irish system of agricultural education.

26. "Agricultural and Mechanical Colleges." U.S. Bureau of Education. Report of Commissioner (I907), 869-924.

The first part of this chapter is devoted to general statements includ. ing summary of legislation; the second part is statistical.

27. "Agricultural and Mechanical Colleges." Ibid. (I908), 737-69.

28. "Industrial Education." Ibid. (I908), 84-89.

The full text of the Davis bill (H.R. I 8,204 ) is given. 


\section{I36 AGRICULTURAL EDUCATION IN PUBLIC SCHOOLS}

29. "Digest of School Laws." Ibid. (1904), 249-518.

A condensed account of organization of all state departments of education is given and a summary of school laws from time of organization of each state department to I904.

30. State School Systems. EDward C. Elliotr. U.S. Bureau of Education, Bulletin No. 3, 1906.

This contains legislation and judicial decisions relating to public education from October 1, 1904, to October 1, 1906.

31. Idem. Bulletin No. 7, 1908.

This contains legislation and judicial decisions relating to public education from October I, 1906, to October I, 1908.

32. Course of Study for Departments of Agriculture and Home Economics. V. L. Roy. Baton Rouge, La.: State Department of Education (rgro), 64 .

Most of this bulletin is devoted to agriculture. It includes requirements for departments of agriculture in high schools, outlines of courses of study, syllabi of courses on general agriculture, farm animals, farm bookkeeping, chemistry, dairying, agricultural engineering, entomology, farm crops, field practice, horticulture, rural law, farm management, poultry, shop practice, and soils and fertilizers. Directions to teachers of agriculture are given. A list of apparatus and reference books is also included.

33. Agricultural Projects for Elementary Schools. Julius E. WarRen. The Commonwealth of Massachusetts, Board of Education, Bul. I (IgI I), 53.

"This manual is prepared as a guide to teachers and superintendents in the iritroduction of work in agriculture in elementary schools." It consists of projects including potatoes, corn, tomatoes, beets, Swiss chard, carrots, parsnips, spinich, lettuce, cucumbers, radishes, kohl-rabi, alfalfa, sweet peas; suggestions for garden work, including nature of appeal to pupils, equipment, and general suggestions; laboratory work consisting of twelve exercises such as testing germinating power of small seeds, to show that plants need air, to show that liquids move upward through plants, etc.; collateral work including letters, filing letters, diaries, themes, stories, illustrations, drawing, reading, memory selections, arithmetic, etc.

34. Course of Study for Agricultural High Schools. D. C. HuLL, J. W. BelL, and H. L. Whitfield. Jackson, Miss.: State Department of Education (I9I0), 8.

Among the subjects discussed are: How to establish an agricultural high school; How to make a success of the school; When the school will fail; Inspector of agricultural high schools; Experimental stage of the schools; Course of study.

35. Manual of Agriculture for the Public Schools of Vermont. G. L. Green, L. C. Cook, and T. J. Aввотr. Montpelier, Vt.: State Department of Education (I9I I), 6r.

Sixty-nine exercises in elementary agriculture are given: twenty-two on soils, four on soil chemistry, twelve on seed germination, nine on plant growth, ten on crops, nine on forestry, and four on animal life. Score cards for potatoes, vegetables, cheese, butter, and dairy cattle, and a list of references are also given. 
36. On the Training of Persons to Teach Agriculture in the Public Schools. Liberty Hyde Bailey. Washington, D.C.: U.S. Bureau of Education, Bulletin No. 3 (1908), 53.

The subject is discussed in three parts: $I$, The nature of the problem in (a) elementary schools, (b) high schools, (c) special schools; II, The means of training the teachers $(a)$ those already in service, $(b)$ new teachers; III, The general outlook; the significance of normal work in the colleges of agriculture.

37. Cornell Nature-Study Leaflets. New York State College of Agriculture of Cornell University, Albany, N.Y.: State Department of Agriculture, Nature-Study Bulletin No. I (r904), 607.

This volume is made up of selections, with revisions, from the Teachers' Leaflets, Home Nature-Study Lessons, Junior Naturalist Monthly, and other publications from the College of Agriculture of Cornell University.

38. Rural School Leaflet. New York State College of Agriculture of Cornell University, Ithaca, N.Y.

Vol. I of this publication began in September, 1907. It is published monthly in the interest of the rural schools. It takes the place of the various other nature-study publications sent out by this institution: Teachers' Nature-Study Leaflets, beginning in 1897; the Junior Naturalist, from I901 to 1904; Nature-Study Quarterly, beginning in 1899; Home NatureStudy Lessons, beginning in 1900, new series in 1904.

39. The Junior Agriculturalist. C. A. Stebsins, editor. Berkeley, Cal.: University of California, College of Agriculture.

"A little paper issued twice a month for the boys and girls of California." The first number appeared March 18, 1911. This paper was planned primarily to reach the boys and girls who are studying agriculture with the extension work of the University Agricultural Department. Each number consists of two kinds of contributions: suggestions to pupils, and letters from pupils giving accounts of their work.

40. Agricultural Education. J. H. Mrller, editor. Manhattan, Kan.: Kansas State Agricultural College. Vol. I began November, 1908.

No regular dates of publication are announced, but it is intended that at least four numbers will be issued each year. Each number takes up somewhat in detail some one subject; Vol. I, No. I, A Corn Primer, pp. 46; No. 2, Plant Breeding, pp. 92; No. 3, A Study of Insects, pp. 52 ; No. 4 , Insects Injurious to Farm Crops, pp. 9I; No. 5, Boys' and Girls' Contest Number, pp. 22.

An educational series of four numbers appeared in 1907, being special editions of The Industrialist, a weekly publication of the College. Previous to 1907 occasional numbers devoted to agricultural education appeared from time to time.

4r. The Agricultural College Extension Bulletin. A. B. Graham, editor. Columbus, Ohio: Ohio State Agricultural College. Vol. I began October, 1905 .

Each volume consists of nine numbers published monthly. Each number treats some subject of interest to teachers and pupils of rural schools. Each year one number is devoted to the centralized schools in Ohio. 
42. New Hampshire College School Bulletin. E. Dwight Sanderson, editor. Durham, N.H.: New Hampshire State College of Agriculture. Vol. I began May, roo8.

This is a quarterly publication in the interest of New Hampshire schools. Contents of Vol. I, No. I, Agriculture through the Rural Schools; No. 2, Soil Studies; No. 3, Seeds and Seedlings; No. 4, Seed Testing.

43. The Nature Guard. A. E. StonE, editor. Kingston, R.I.: Rhode Island State College of Agriculture. Vol. I began October, I899.

This leaflet is issued monthly from October to May. It is the official organ of the Nature Guard and Junior League of Improvement Societies of Rhode Island. Each number has from four to eight pages and is usually devoted to one subject; for example, the title of No. 63 is Experiments with Soils.

44. West Virginia School Agriculture. D. W. WorkING, editor. Morgantown, W.Va.: West Virginia College of Agriculture.

Vol. I of this publication began in November, 1910. It is published monthly from November to April inclusive. Each number is devoted to some special phase of agriculture adapted for use in public-school instruction, e.g., Nos. 4-5 (pp. 67-88), Vol. I, to "Judging and Testing Corn." It is arranged in a series of lessons: The purpose of corn judging; How judging is done; The score card; Selecting seed corn; Will the corn grow; Will the corn yield; Will the corn mature; Is the corn improving; The profit in testing corn; Making the tester; Making the test; Conclusions from the test.

45. Public School Agriculture. W. R. HaRT. Amherst, Mass.: Massachusetts State College of Agriculture. Special Bulletin (I909), 32.

This is the Report of the Committee Appointed at the Conference on Agricultural Science at Amherst, Mass., 1908. Fifty-four exercises in elementary agriculture are outlined.

46. Proceedings of the Conference on Agricultural Science. Ibid. (1908), 43.

Four papers are published as follows: "The Place of the School Garden in the Development of Science Teaching," W. A. Baldwin; "Administrative Phases of Agricultural Instruction," C. H. Robison; "Physics and Agriculture," R. W. Guss; "Chemistry and Agriculture," Charles Wellington.

47. Proceedings of the Second Annual Conference on Agricultural Science. Ibid. (rgo9), 59.

Six papers are published: "Nature-Study and Agriculture in Rural Schools," M. A. Bigelow; "Elementary Agriculture as a Subject of Study in the Grades," W. R. Hart; "Some Connections between School Studies and Home and Industrial Activities," Hannah P. Waterman; "Relation of the Physical Sciences to Agriculture," S. B. Hasskell; "Biological Sciences in their Relation to Agricultural Science," E. D. Sanderson.

48. Proceedings of the Third Annual Conference on Agricultural Education. Ibid. (19I0), 30.

Seven papers are published: "Co-ordination between Garden Work and Nature Work and Book Work," G. L. Green; "How Agriculture Put Life into a Rural School," Ethel H. Nash; "The Story of Pinehurst Gardener's Club," A. Green; "Rural School" and Home Gardens during Summer," Elizabeth Hill; "Gardening in the Schools of Springfield," 
Fannie A. Stebbins; "Home Gardens of the Worcester Public Schools," E. R. Thayer; "Some Suggestions for Beginning Garden Work," W. R. Hart.

49. Extension Bulletins Relating to Agricultural Education. Illinois State Agricultural College, Urbana, Ill.

Consolidation of Country Schools, E. Davenport (1903, ad ed., 1904), 56. Developing the Farm Boy, Fred H. Rankin (1905), 26. The Grout Farm Encampment, Arthur J. Bill (1906), 42; Second Encampment, ibid. (1907), 40. Dairy Lessons, Wilbur J. Fraser (1907), four parts, one lesson in each. The Next Step in Agricultural Education, E. Davenport (1908), 22. Sugar Beets and How to Grow Them, Fred H. Rankin (1908), 7. How to Run Farm Machinery, Fred R. Crane (1908), 39.

50. Rural Education: The Soil. R. H. Emberson. Columbia, Mo.: Bulletin of the University of Missouri, X, No. ro (I9I0), 8.

This bulletin is intended for use of teachers in the rural schools but may be used by pupils of advanced grades. It consists of six lessons: How soils are formed; The kinds of soil; Soil texture; Soil tilth; The capillary water in soils; The free water in soils.

51. Public School Agriculture. T. I. MaIrs. State College, Pa.: The Pennsylvania State College Bulletin, IV, No. 5 (rgro), r3.

This bulletin contains a general discussion of agriculture with special reference to public schools, list of books and printed matter, equipment for agricultural instruction, suggested course for second- and third-class high schools.

52. A Manual for High Schools. Josiah MaIN. Knoxville, Tenn.: Tennessee State College of Agriculture, Special Bulletin (I909), 32.

A scheme for correlating agriculture with other high-school sciences is worked in with considerable detail.

53. Rural School Agriculture. W. M. HAyes, et al. St. Anthony Park, Minn.: University of Minnesota, Bulletin No. I (Ig03), 200.

"Exercises in this bulletin .... have been prepared for use of teachers in the rural schools of Minnesota." This publication is of especial interest because it represents one of the first efforts of agricultural colleges to assist teachers by preparing concrete lessons in an agricultural subject. A revised edition of this bulletin appeared as Bulletin No. $z$ in 1907. A comparison of the two bulletins shows an interesting shifting point of view as to matter presented and method of presentation.

54. Suggestions for Garden Work in Culifornia Schools. E. B. BABCock, Berkeley, Cal.: California State Agricultural College, Circular 46 (Igog), 48.

This contains a history of the movement, what teachers have done, what teachers can do, instructions for teachers beginning garden work, how to secure special preparation for teaching nature-study within California, and list of publications.

55. Tree Growing in the Public Schools. E. B. BABсосK, University of California. Ibid., Cir. 59 (IgrI), I9.

All the necessary directions for tree growing are given. The circular discusses tree growing in the public schools, best trees for children to grow, how to grow trees, boys' and girls' clubs, tree seed exchange, best free literature on tree study, best books on trees. 
56. "Agriculture in the Public Schools." C. A. Stebrins, editor. San Francisco, Cal.: Town and Country Journal.

Since the beginning of the year 1911, a series of lessons in agriculture for rural schools have appeared biweekly in this journal. These lessons are especially well outlined for teachers, giving general aim, specific lesson aim, method of approach, and lesson in detail.

57. An Elementary Laboratory Study of Crops. Jos. A. JEFfery. Lansing, Mich.: State Department of Education, Bulletin No. 26 (1907), 28.

An Elementary Laboratory Study in Soils. Jos. A. JeFfery. Ibid., Bulletin No. 27 (1908), 36.

An Elementary Course in Horticulture. S. W. Fletcher. Ibid., Bulletin No. 28 (Igo8), 3 I.

58. The Study of Farm Crops, Farm Animals, Horticulture and Agriculture. A. D. Shamel, E. Davenport, and J. S. Blatr. Taylorville, Ill.: C. M. Parker, The School News (1900-4).

About fifty short articles on the above subjects were published in the School News and afterward reprinted by the publisher in form of leaflets, and sold at one cent each in quantities of ten or more. They had a wide sale and no doubt contributed much toward arousing an interest in agriculture in the public schools of Illinois.

59. Correspondence Courses in Agriculture. T. S. MAIRs. State College, Pa.: Pennsylvania State College of Agriculture, Special Bulletin (1909), I6.

This bulletin contains announcement of "thirty-one courses of study. Each course consists of from five to nine lessons and is expected to occupy the time of the student for a week or two." This study is intended for the farmer, the dairyman, the gardener, the nurseryman, the florist, the teacher, and others who may be interested.

60. Nebraska Boys' and Girls' Association State Contest and Convention. VAl. Keyser and E. C. Bishor. Lincoln, Neb.: University of Nebraska Bulletin, Ser. XIV, No. I2 (I909), 20.

This bulletin contains announcement of the State Convention of 1910 of the Boys' and Girls' Association of Nebraska. Other bulletins concerning this Association have appeared from time to time, e.g., Selecting Corn for the Contest, Ser. 12, No. 25; Planting Corn for the Contest, Ser. 12, No. I2 (1907); Selecting Potatoes for the Contest, Ser. I3, No. II (1908); Cooking and Sewing, Ser. 13, No. 14 (1908).

6r. "Boys' Agricultural Clubs." D. J. Crosby. Washington, D.C.: U.S. Department of Agriculture, Yearbook for r 1904, 489-96.

This article gives a description of "the boys' exhibit of corn at the Louisiana Purchase Exposition, the development of boys' clubs in Illinois and other states, and school fairs; and discusses the educational value of the work done by such organizations."

62. Outline of the Courses in Science. Madison, Wis.: Board of Regents of State Normal Schools (r9or), 32.

Each of the subjects of instruction in the state normal schools is briefly outlined. About seven pages are devoted to agriculture and include purpose of subject, scope (soil, plant and crops, animals and stock), and plan. 
63. "Shall Teachers Be Prepared to Give Instruction in Elementary Agriculture?" B. M. DAvis. The Western Journal of Education, May, I $906,5-15$.

This is a report submitted to the Joint Board of the California State Normal School Trustees at its annual meeting held at Chico, Cal., Apri! 15, 1906. It discusses the organization of agricultural education in the United States, agriculture in the elementary schools, work in Canada, N.E.A. report on industrial education in schools for rural communities. work of the normal schools, the problem as concerns the California normal schools including a tabulation of answers to questionnaire sent to all the county superintendents of the state, and a discussion of the work of the normal school.

64. "What Has Been Done by Normal Schools and Agricultural Colleges for Popular Education in Agriculture." E. E. BALCoxB. Proceedings of the National Education Association for 1907, 1069-75.

This report is a summary to answers to letters to the president of each agricultural college, to each state normal school, and to certain other schools of the United States.

65. Education for Efficiency. E. Davenport. Boston: D. C. Heath \& Co. (1909), 184 .

Its subtitle is "A discussion of certain phases of the problem of universal education with special reference to academic ideals and methods." The book is in two parts: the first, a discussion from general educational standpoint including education for efficiency, industrial education with special reference to high school, as a phase of the problem of universal education, educative value of labor, culture aim and unity in education; the second, an illustration of the principles discussed in first part as applied to agriculture-including agriculture in the high school, in the elementary school, in the normal school, and the development of agriculturewhat it is and what it means.

66. "The Organic Field of Nature-Study." George H. Hudson. NatureStudy Review, Vol. III, No. 5 (I907), I 29-35.

A scheme is given outlining the subject in considerable detail in two parts; one, the physical or practical, the other, the psychical. Both are amplified by a discussion which follows.

67. School Gardens for California Schools. B. M. DAvis. Chico, Cal.: State Normal School Bulletin No. I (1905), 79.

This is a manual for teachers. It discusses the history of school gardens and their educational importance, the plant and its relations, plant propagation, instruction including aim and scope, practical work, correlative subjects, adaption to school conditions, etc. The annotated bibliography of nearly three hundred titles is a summary of the literature of the subject up to I 905 .

68. Normal School Instruction in Agriculture. N. J. Aвbey. U.S. Department of Agriculture, Office of Experiment Stations, Circular 90 (I 909 ), 3I.

This circular "sets forth in a brief way the manner in which agriculture is taught at the Maysville State Normal School, No. Dakota." It contains a discussion of why normal schools should train teachers in 
agriculture and the place of agriculture in the normal school curriculum. Most of the circular is a detailed account of the work, including textbook instruction, class exercises, laboratory instruction, typical laboratory exercises, apparatus, the school garden, the model school, visiting a rural school, field excursions, methods, correlation, and difficulties.

69. Normal Agricultural Society. Charles R. Weens. Peru, Neb.: State Normal School, Special Cir. (I909), I.

This circular gives history, purposes, and plans of this organization.

70. Western Illinois State Normal Experiment Field. J. T. JoHnson. Macomb, Ill.: State Normal School, Cir. I (I907), 4.

The circular contains statement of purpose, location, and plans of conducting the soil experiment field.

71. A Correlated Course of Study in Agriculture, Geography, and Physiology for Rural Schools. E. A. CockefaIr. Cape Girardeau, Mo.: State Normal School, Special Bulletin (1909), 63.

It contains daily program of recitation; general outline including such subjects as seed, corn judging, corn selection, corn breeding, how corn grows, the soil, crops, foods, live stock judging, markets, dairying, gardening, fruit growing, forestry, cooking, sewing, home decoration; elaboration of outline.

72. Elementary Horticulture for California Schools. C. F. PALMER. Los Angeles, Cal.: State Normal School, Bul. (I9ro), 76.

The following subjects are discussed: The school garden; The lathhouse; Seed-sowing in boxes; Transplanting; Propagation of plants; Potting and repotting of plants; House plants; Window boxes and their care; The planting and care of bulbs; The inside miniature farmstead; Lawnmaking and care; Ornamental gardening; Where to obtain seeds and plants; Publications of the U.S. Department of Agriculture.

73. Agriculture and Nature-Study for Rural Schools. H. W. HochBaum. Greeley, Colo.: State Normal School Bulletin, Ser. Io, No. 5 (I9I0), 44.

The subject is discussed as follows: Why the rural schools are inefficient; The work of the rural school needs to be redirected; The aims in teaching nature-study and agriculture; How to redirect the work of rural schools; Some suggestions for nature-study and agriculture; Outline of subjects for nature-study and agriculture.

74. Educational Agriculture. JosiaH Main. Hays, Kan.: Western State Normal School Bulletin, II, No. 3 (I9I0), 74.

This bulletin consists of three parts: Part I, Introduction: Limitations of the field as a realm of knowledge; Part II, Organization; Motives, Genetic psychology as an aid to organization, The kinaesthetic factor in apperception-reaction and inhibition, A problem of readjustmentposition of the various sciences: Formal discipline and its transfer: Humanistic science, applied science, and agriculture; Agricultural arts - habit v. judgment, Collateral or extra program agriculture, The essential order of presentation. Other correlated subjects, Retardation-admission $\rightarrow$ graduation-and accrediting of students. Part III, Equipment: The laboratory, Plots and grounds; Agricultural literature. 
75. Course in Nature-Study and Elementary Agriculture. RILEY O. JoHNSON. Chico, Cal.: State Normal School, Special Circular (I908), 8.

The work outlined in this circular is designed for the ungraded schools of California. There are three parts: (I) an outline of the work, (2) specimen lessons, and (3) a list of references.

76. Rural Industrial Education. B. M. Davis. Oxford, Ohio: Miami University Bulletin, Ser. VIII, No. 9 (IgIo), 15.

A general discussion of the problem of rural industrial education with especial reference to Ohio conditions. This discussion is followed by an outline of course for high-school teachers offered in the Ohio State Normal College, Miami University.

77. "Historical Sketch of the National Educational Association." Z. RICHARDS. Proceedings of the National Educational Association for I89I, I I 8-33.

78. "Bibliography of Topics from I857-1907." Ibid. (I906), 659-730.

This is a classified list under fifty-nine heads.

79. "Should Rural Schools Introduce Agriculture, Chemistry, Agricultural Botany, or Arboriculture?" Ergraff De Kovalevskx. Ibid. (I893), 304-7.

The writer concludes that "instruction in the rural schools can and should have an agricultural bearing."

80. "Report of the Committee of Twelve on Rural Schools." Ibid. (1897), $385-582$.

This is probably the most complete and important contribution of rural schools in American educational literature up to the date of its publication. Besides a full discussion of the four phases of the subject there are nineteen appendices devoted to such subjects as transportation of pupils, enrichment of the rural-school course, the rural-school problem, the course of study, the farm as a center of interest, etc.

8I. Report of the Committee on Industrial Education in Schools for Rural Communities. Publications of National Educational Association: Report of Special Committee (1905), 87.

This report contains argument for industrial work, scope of work, statements of what kind of work was being done in the different types of schools in which a beginning in industrial education had been made, and the desirability of a new type of secondary school of distinctively industrial character and adapted to the needs of rural communities.

82. Idem. "Supplementary Report." Proceedings of the National Education Association (1907), 409-46.

83. Idem. "Second Report." Ibid. (1908), 385-448.

84. "Conference of National Committee on Agricultural Education." Ibid. (1907), 1063-84. 
85. Proceedings of the Nineteenth Annual Convention of the Association of American Agricultural Colleges and Experiment Stations. U.S. Department of Agriculture, Office of Experiment Stations, Bul. I64 (1905), r89.

In the detailed account of the convention considerable attention is given to agricultural education: Agricultural education in the National Education Association; Methods of teaching agriculture; Address of the U.S. Commissioner of Education.

86. "Educational Periodicals." U.S. Bureau of Education. Report of the Commissioner (I 906 ), 257-59.

This is a list of educational periodicals in the United States in 1906 that are in the library of the Bureau of Education.

87. "Henry Barnard." C. H. Thurber. School Review, VIII (1900), 505-6. A tribute to the life and work of Henry Barnard.

88. "Fellenburg and Manual Labor Schools." Henry Barnard. Barnard's Journal of Education, XV (1865), 232-34.

An account of the influence of Fellenburg's Agricultural School at Hofwyl on the establishment of similar schools in this country.

"Plan of an Agricultural School." John A. Porter. Ibid., I (1856), 329-35.

89. "Josiah Holbrook." Henry BARnARD. Ibid., VII (1860), 229-47.

89a. "Primary Instruction by Object Lessons." Ibid., XII (r862), 605-45.

This is a report of a committee selected by the Board of Education of the city of Oswego, N.Y., to attend an examination of the primary schools of that city with special reference to an investigation of the system of object-teaching recently introduced into these schools.

90. "Pestalozzi, De Fellenburg and Wehrli, and Industrial Training." Ibid., $\mathrm{X}(1876), 8192$.

Republished from the Transactions of the National Association for the Promotion of Social Science, 1858.

91. "Preventive and Reformatory Education." Henry BARNARD. Ibid., III (I858), 56r-8I8.

A very complete discussion of the subject including the work in foreign countries as well as in our own country.

92. "Scientific Instruction." HENRY BARNARD. Ibid., XXI (187I), 807.

93. "Newer Ideas in Agricultural Education." L. H. BAlley. Educational Review, XX (1900), 377-82.

94. "A Significant Factor in Agricultural Education." Kenyon L. ButterFIELD. Educational Review, XXI (rgor), 30I-9.

Extension work advocated.

95. "Place of Nature-Study, School Gardens and Elementary Agriculture in Our School System." J. R. Jewell. Pedagogical Seminary, XIII (1906), 273-92.

This is preliminary to a more complete presentation of the same subject (25). 
96. "Agricultural High Schools." Frederick E. Bolton. School Review, XVI (1908), 56-58.

An editorial note.

97. "The Agricultural High School." Arthur D. CROMwell. Ibid., I98200.

A rejoinder to $(96)$.

98. "The Correlation of High-School Science and Agriculture." JosiaH MaIN. Education, XXX (I909), I35-45.

99. "Shall Secondary Agriculture Be Taught as a Separate Science?" G. A. BRICKER. Ibid., 352-56.

A view directly opposite to that expressed in (98) is presented.

I00. "The Methods, Content and Purpose of Biologic Science in the Secondary Schools of the United States." G. W. Hunter. School Science and Mathematics, X (I9I0), I-IO, I03-II.

ror. "Introduction" (to first number). M. A. Bigelow. Nature-Study Review, I (1905), I-2.

102. "School Work in Agriculture." D. O. BARTo (Taylorville, Ill.). School News, XXI (1907).

A department of this magazine for aiding teachers to make use of the prescribed state course of study in elementary agriculture.

I03. "Lessons in Agriculture and Home Economics." E. C. Bishop (Lincoln, Neb.). Nebraska Teacher, XII (I9Io).

A series of articles to aid teachers in their work with the Nebraska boys' and girls' clubs.

I04. "Learning by Doing for the Farmer Boy." O. J. KERN. Review of Reviews, XXVIII (1903), 456-6r.

A description of the Farmer Boys' Club organized in Winnebago County, Ill., February 22, 1902. It includes method of organization, educational excursions, experimental work of the boys, local meetings of the club, the club and the farmers' institute, future outlook of the club. There is also a short account of the first consolidated school in Illinois.

105. "Common-Sense Country Schools." Adele MARIE Shaw. World's Work, VIII (I904), 488I-94.

An illustrated account of O. J. Kern's work among the rural schools of Winnebago County, I1l. It contains a good account of the Farmer Boys' Club.

I06. "The New Education for Farm Children." Willet M. Hays. Review of Reviews, XXVIII (I903), 449-55.

The article is introduced by a general discussion of the educational situation, concluding that there should be a school system adapted to rural conditions. A scheme is presented for an articulated system of education adapted to rural needs: (1) consolidated rural school ; (2) agricultural high school; (3) agricultural college. This is one of the first publications of the author's views on a system of rural education. His present views on this subject have been reviewed at some length in a previous article of this series (15). 
107. "Teaching Farmers' Children on the Ground." George Iles. World's Work, VI (Ig03), 34I 5-20.

After a general discussion of rural education, its needs and shortcomings, the author gives an account of the program for rural educational reform, known as the Macdonald Consolidated Rural School Movement, which was to take effect in Canada the following September. A large number of interesting facts are given not only concerning this proposed reform but also concerning the agricultural work in general in Canada.

108. "Farmer Children Need Farmer Studies." Clarence H. Poe. World's Work, VI (I903), 3760-62.

Reviewed in text.

I09. "Agricultural High Schools" (Editorial). Independent, LVIII (I905), $334-36$.

I I0. "Two Clear Aims in Education" (Editorial). World's Work, XII (Igo6), 7706-7.

These aims are ( 1 ) training for practical purposes, the machinery of which has been perfected only for the professions; (2) training for culture where public good is put before personal aims.

II I. "Agricultural Education in the United States." J. C. MEAD. Nineteenth Century, LX (I906), 299-306.

A popular historical account dealing mainly with agricultural colleges.

I 12. "Agriculture in the Common Schools" (Editorial). Independent, LXIII (I907), I508-9.

Two questions are raised: (1) Are the sciences underlying agriculture to be taught? (2) Where will teachers be found to give adequate instruction along such lines? Both questions are answered, the first by making use of pupils' everyday experiences, the second through training schools for teachers.

I13. "New Work in Education." World's Work, XVI (Igo8), I0453-62. Reviewed in text.

II4. "Catching Them Young." F. G. Moorhead. Technical World, XI (I909), 6r 2-I8.

Reviewed in text.

II5. "The Martian and the Farm" (Editorial). Outlook, XXIX (I909), 433-34.

Reviewed in text.

II6. "Training for Farm Life." D. H. Smalley. Outlook, XXIX (I909), 8II-I 2 .

A reply to (115).

II7. "The Automatic Farm." WM. Halstead. Outlook, XXIX (Igog), 8 I $2-13$.

A reply to (115). 
II8. "Agriculture the Basis of Education." O. F. Coor. Monist, XVII (1907), 347-64.

Reviewed in text.

I 19. "Farm Life as a Basis of Practical Education." Craftsman, XVI (I909), $243-45$.

Some of the plans of the Craftsman Farms are set forth. Active farm operation is regarded as the first step in creating an ideal school environment. "To use the idea of education seems as big and interesting as the whole of life itself. And the farm work which is necessary to make the land productive for our own maintenance and also to make the ground attractive to the eye seems to us to afford a series of experiments, the educational value of which no scientific laboratory could equal."

120. "Need for Agricultural Education." D. Y. Thomas. Annals of the American Academy, XXXV (I910), I50-55.

The purpose of this paper is to "emphasize the advisability" of extending the work in agricultural education. "Education must be democratized and made to subserve the economic interest of man. This will not kill the cultural school but foster it. The man who wants to be a lawyer or a doctor or a teacher or a journalist will have a hundred opportunities where he now has one."

I21. "Social Problems of American Farmers: Rural Education." KENYON L. Butterfield. American Journal of Sociology, X (I905), 6I5-I9. Reviewed in text.

122. "State Organizations for Agriculture." Encyclopedia of American Agriculture, IV (I909), 328-39.

A brief general account is given, followed by short sketches of the various state organizations.

123. "Agricultural Education." A. W. Gilmax. Seventh Annual Report of the Commissioner of Agriculture of the State of Maine (I908), I I-I 2.

Reviewed in text.

124. An Address-no title. P. G. Holden. Annual Report of the Nebraska State Board of Agriculture (I909), I I 2-37.

A stenographic report of an address supposed to be upon corn but a considerable portion of it relates to rural education, and offers many valuable suggestions on this subject.

I25. "Some Rural Problems." Wallace. Ibid. (г910), r 24-39.

Four problems are discussed: maintenance of soil fertility, farm labor, education, and socialization of farm life. Mr. Wallace was a member of the Country Life Commission. His discussion of rural education, therefore, is of more than ordinary interest.

126. "Rural Education." A. C. TRUE. Annual Report of the Pennsylvanio Department of Agriculture (I907), 23I-36.

General improvement of rural schools is regarded as necessary and certain to be brought about. Better teaching, consolidation, attention given to nature-study and agriculture in public schools are suggested as means of improvement. 
I27. "The Most Useful School in the Country." D. J. Crosby. Ibid. (rgo9),
$257-63$.

Two small country schools are described in considerable detail as illustrating the possibilities of a rural school: one at Calvert Center, Md., the other at Waterford, Pa.

128. Steps in Agriculture. S. M. JoRdoN. Monthly Bulletin, Missouri State Board of Agriculture, VIII, No. 8 (1910), I36.

This contains simple studies to help "teachers interest our boys and girls in better farming" as follows: the stand of corn, leaves or blades, roots, flowers and blossoms, yield, corn judging, score card, seed selection, weeds, insects, flies, grafting and budding, crossing, diseases of plants, wheat and oats, clovers and cowpeas.

I29. Boys' and Girls' Contests. A. E. Chamberlain. South Dakota State Board of Agriculture, Special Bulletin (Igro), I-I 5 .

Reviewed in text.

130. The School of Agriculture at the State Fair. S. E. ANDREws. Oklahoma State Board of Agriculture, Monthly Press Bulletin, Series rgro, No. 7 (September), 8-9.

An account in detail of how the school is to be conducted.

I3I. Boys' State Fair School. Springfield, Ill.: Illinois State Fair Association, Announcement (I9II), I5.

This gives an account of the first annual Boys' State Fair School held in 1910. "The aim of the school is to offer to a well-selected body of young men the means for systematic observation and study" of the great agricultural and mechanical exhibits of the state fair.

132. Agricultural Schools. E. J. Martin. Office of Commissioner of Agriculture, Commerce and Industries of South Carolina, Sixth Annual Report (1909), 93-94.

An account of agricultural demonstration work in connection with certain high schools.

I33. Agricultural Fair Associations and Their Utilization in Agricultural Education and Improvement. JohN Hamiston. U.S. Department of Agriculture, Office of Experiment Stations, Cir. rog (I9I I), 23.

"This circular is the result of extended study of the conditions that exist in the various states in connection with county fairs, and is a contribution toward increasing their usefulness by suggesting lines of effort along which they can act for the betterment of educational, social, and economic conditions in rural communities."

134. History of Farmers' Institutes in the United States. John Hamlton. U.S. Department of Agriculture, Office of Experiment Stations, Bulletin I 74 ( 1906$), \mathrm{I}-96$.

As the name indicates, it is a historical account of farmers' institutes in the United States. It is divided into five parts: introduction, historians, government aid to institutes, American Association of Farmers' Institute Workers, institutes in the several states and territories. 
135. "The Farmers' Institutes in the United States, I908." JoHn Hamilton. U.S. Department of Agriculture, Office of Experiment Stations, Annual Report of the Office of Experiment Stations (1908), 289-335.

A summary of the work of farmers' institutes for 1908 giving institutes held, sessions, attendance, appropriations, and other data concerning the year's work.

136. The Origin of the Land Grant Act of 1862 and Some Account of Its Author. Edmund J. James. University of Illinois Bulletin, VIII, No. ro (I9ro), I39.

"It is proposed to prove in this paper that Jonathan B. Turner, at one time professor in Illinois College at Jacksonville, Ill., was the real father of the so-called Morrill Act of July 2, 1862, and that he deserves the credit of having been the first to formulate clearly and definitely the plan of a national grant of land to each state in the Union for the promotion of education in agriculture and mechanic arts, and having inaugurated and continued to a successful issue the agitation that made possible the passage of the bill ...." (p. 7).

A reprint of the Turner pamphlet, "Industrial Universities," is appended. This contains an excellent discussion of industrial education, much of which has present-day application.

137. Michigan State Association of Farmers' Clubs. Proceedings of the Seventeenth Annual Session (1909), 56.

Besides a report of the proceedings there is included resolutions regarding state and national affairs, and constitution and by-laws of the Association.

I38. "What Shall We Teach the Farm Child?" H. W. Collinwoon. Proceedings of the New Jersey State Horticultural Society, Thirty-fifth Annual Session (1909), I69-74.

Reviewed in text.

I39. "Agriculture in Our Public Schools." William Langham. Proceedings of the Iowa State Horticultural Society, XLIV (1909), I47-54.

Reviewed in text.

140. "Report of Committee on School Gardens and Children's Herbariums of the Massachusetts Horticultural Society." Transactions of the Massachusetts Horticultural Society. I894-1907.

Beginning with 1894 and continuing to 1907 these reports of the committee on children's school gardens appeared in the transactions of the Society. After 1907 the Society discontinued the special school-garden feature of its meetings and of its transactions.

I4I. Boys' and Girls' Agricultural Clubs. F. W. Howe. U.S. Department of Agriculture, Farmers' Bulletin No. 385 (1910), 23.

This bulletin contains history, plans, and recent development of these clubs under the following heads: Introductory Summary of Results; How Work Has Been Accomplished in Several States; Assistance Given by the Department of Agriculture; The Relation of Club Work to Rural Education; Suggestions for Organization; List of References; Statistics. 
142. Agricultural Clubs in Rural Schools. Homer C. PrICE. Ohio State University Bulletin, Ser. 7, No. 10 (1904), I4.

The bulletin contains suggestions for organizing clubs in the rural schools of Ohio. These suggestions are the outgrowth of the previous year's experience of the first club formed in Ohio under the auspices of the students of the Agricultural Union. This bulletin is of special interest because it represents the beginning of organized effort to develop agricultural clubs in Ohio.

I43. Farmers' Institutes for Young People. John Hamilton. U.S. Department of Agriculture, Office of Experiment Stations, Circular No. 99 (I910), 40.

This circular calls attention to "lack of adequate means for giving vocational training in agriculture to young people in rural districts after they leave the public school and before they enter upon their life occupations." Boys' and girls' clubs, farmers' institutes for young people, subjects for institute study, systematic course for contest work, boys' encampments, form of organization, season for meeting, states and territories in which young people's institutes are organized, model constitution for young people's institutes, order of topics for boys' institute, score cards for various products are some of the subjects discussed.

144. Boys' Agricultural Club Bulletin. Jessie Fiesd. Office of County Superintendent of Schools, Clarinda, Ia. (r9o9), I4.

This bulletin gives an account of the boys' club of Page County, Iowa, including summary of results of 1908 and plans for 1909.

145. The Winnebagoes. O. J. KERN. Office of County Superintendent of Schools, Rockford, Ill. (1903), 64 .

This is a report of the Winnebago County (IIl.) schools, with suggestions for their improvement. One chapter (pp. 39-49) is devoted to boys' and girls' clubs. An account is given of the Boys' Experimental Club organized in 1902. This was one of the first boys' agricultural clubs organized in the United States.

r46. Among Country Schools. O. J. KerN. New York: Ginn \& Co. (1906), 366.

This is one of the best contributions to rural education that has been written. One chapter is devoted to a Boys' Experiment Club (pp. 129-57).

Only titles cited by number in text are included in the following list:

147. "What Constitutes Successful Work in Agriculture in Rural Schools?"

B. M. Davis. Proceedings of the National Education Association for I908, II 89-94.

This discussion is based on a study of replies to a questionnaire addressed to teachers and others interested in agricultural education.

148. "The District Schools in a County as Educational and Social Centers." Jessie Field. National Society for the Study of Education, Tenth Yearbook, Part II (I9II), I 7-I9.

In the county system described agricultural studies are an important means for bringing the school and community into a closer relation. The subjects are not uniform in the various schools of the county but are chosen primarily because of some dominant community interest. 
149. "The Present Status of Agricultural Education in the Public Secondary Schools of the United States." C. H. RoBrson. School Revierw, XIV, No. 5 (I9II), 333-44.

This article contains summary of agricultural instruction in secondary schools from 1907 to 1910 . Considerable attention is paid to efficiency and cost of instruction.

I50. Agricultural Instruction in the Public High Schools of the United States. C. H. Robison. Teachers 'College, Columbia University (I9ro), 205.

This book deals with the present status of agricultural education in the secondary schools of the United States. The chapter headings are as follows: "The Public High School"; "Some Types of High Schools"; "Special Secondary Schools of Agriculture"; "Problems of Agricultural Instruction in the Secondary Schools." Two appendices, one on legislation, the other giving a very complete list of references, are added. This is a valuable reference book on agricultural education bringing together, as it does, an immense amount of data hitherto inaccessible.

I5I. The Teaching of Agriculture in the High School. G. A. BrICKer. New York: Macmillan (I9II). XXV, 202.

The subject is considered from a teaching standpoint in the following chapters: "Nature of Secondary Agriculture"; "Rise and Development of Secondary Education in Agriculture in the United States"; "Social Results"; "As a Separate Science"; "Psychological Determination of Sequence"; "Seasonal Determination of Sequence"; "Organization of the Course"; "Aims and Methods of Presentation"; "Organization of the Laboratory and Field Work"; "Illustrative List of Classified Exercises"; "Educational Aims, Values, and Ideals." This is the first attempt to present in detail the problems of secondary agriculture from the point of view of instruction.

152. The School of Agriculture. University of Minnesota Bulletin, XIII, No. ro (I910), 66.

Annual announcement of the School of Agriculture connected with the University of Minnesota.

153. Secondary Agricultural Education in Alabama. C. J. Owens. United States Department of Agriculture, Office of Experiment Stations, Bulletin 220 (I909), 30.

This bulletin contains "concrete information as to methods of organizing courses of study, needed equipment, and cost of secondary agricultural schools.

I54. First Annual Report of the Congressional District Agricultural Schools of Georgia. Georgia State College of Agriculture, Bulletin for December, I909.

A complete account of the organization of these schools is given.

I55. Agricultural High School. B. H. CRocheron. Philopolis, Md.: Prospectus of the Baltimore (Md.) Agricultural High School (I909).

A brief account of the foundation, purpose, entrance requirements, courses of study, and equipment of this school. 
I 56. "Community Work in the Agricultural High School." B. H. CrochERON. National Society for the Study of Education, Tenth Yearbook, Part II (I9II), 9I-6.

A detailed description of the community work undertaken by the Baltimore (Md.) County Agricultural High School. It includes an account of the school, its organization, and work among the farmers, farmers' wives, and young people of the community. This paper shows the great possibilities of a rural high school in its service to an entire community, children and adults as well.

157. Elementary Agriculture in the New Holland (Ohio) High School. G. A. Bricker. Ohio Agricultural College Extension Bulletin, III, No. 7 (I908), 6.

A brief description of the organization of work in agriculture with concrete examples of some of the things actually accomplished.

158. "The John Swaney School." V. C. Kays. Nature-Study Review, IV, No. 9 (I 908 ), 27 I -75 .

An account of the history and of the first two years' experience of this school. It is in the country, "planned and built by country people for the education of country children."

I59. Opportunity for the California High School: Industrial and Agricultural Education. Edward Hiatt. California State Department of Education, Special Bulletin (July, I910), 21.

This bulletin describes the plans for introducing agriculture into the high school of the city of Stockton, Cal.

160. "Agriculture in the Secondary Schools of California." E. B. BABCock. Nature-Study Review, V (1909), 210-18.

The work of several high schools giving instruction in agriculture is described. The article includes extracts from a report of F. H. Bolster of the Gardena (Los Angeles City) High School. This is of particular interest as it is claimed that the Gardena High School is the first city high school to "offer agriculture as the one principal purpose of the school."

16r. The State High School. A. E. PrCKard. Hinckley (Minn.) High School Bulletin (1910), 23.

A full account of this school is given, including courses of study, general information as to admission, expenses, certificates, scope and purposes of courses, etc., detailed description of work offered in agriculture, manual training, domestic science, and normal work. This school is one of the ten high schools of Minnesota receiving state aid. All of these schools are similar in organization to this one.

162. Schools of Agriculture, Mechanic Arts, and Home Making. F. W. Howe. New York State Department of Education, Special Circular (November I, I9IO).

This circular contains a "general statement in reference to the relations of this type of school to the so-called 'trade schools,' and the responsibility of the Division of Trade Schools in respect to it, and the text of the law relating to these schools, notes on this law, brief descriptions of some typical 
schools teaching agriculture, mechanic arts, and home-making, a list of books, periodicals, and national and state publications dealing with agriculture, farm mechanics, and household economy."

I63. "Syllabus for Secondary Schools: Agriculture." Ibid., Annual Report (I9IO), III, I-IO2.

This syllabus includes apple growing, general fruit growing, cereal and forage crops, potato growing, dairy husbandry, animal husbandry, poultry husbandry. Each subject is presented as a series of exercises, giving the object of the exercise, materials, and directions for study.

164. "Department of Agriculture." E. A. CockeraIR. Cape Girardeau, Mo.: The Missouri State Normal School Bulletin, Catalogue Number (I9og), 63-67.

A description of objects of work offered and detailed outline of course of study. It is of particular interest because provision is made for giving instruction to farmers as well as to teachers.

165. "The Curriculum of the Agricultural High School." Stuart G. Noble. The Mississippi School Journal, XV (IgII), 7-II.

The writer presents the results of a detailed study of the curricula of the agricultural high schools of Alabama, Georgia, and Mississippi.

166. Report of the Board of Education on Agricultural Education. R. W. Strmson, et al. Massachusetts State Department of Education, Special Report (I9II), I04.

This report was prepared for the state legislature which requested that an investigation be made as to the advisability of establishing a system of agricultural education throughout the commonwealth. The matter presented in this report is a valuable contribution to the literature of agricultural education because it outlines some plans not hitherto undertaken in agricultural instruction.

167. "Report of Committee on Encouraging College-Entrance Credit in HighSchool Agriculture." A. B. Graham, Proceedings of the National Education Association for I9Io, 480-83.

This report is the result of an investigation of a committee appointed the previous year by the Department of Rural and Agricultural Education of the N.E.A.

168. "Practical Aspects of Science in Secondary Education." W. R. HART, et al. Ibid., 446-80.

This general topic was discussed at a joint session of the departments of secondary, of science, and of rural and agricultural education. Following the presentation of the pedagogical and scientific viewpoints are brief discussions of the subject as related to the various sciences usually taught in high schools.

I69. "An Experiment of Methods of Teaching Zoölogy." J. P. Gilbert. Journal of Educational Psychology (June, I910), 32 I-32.

This paper is a preliminary report of a series of investigations "to determine the relative merits of the pure-science and applied-science methods of approach in teaching secondary science." 
I 70. Idem, School Science and Mathematics, XI, No. 3 (March, I9II), 205-15.

A further report of the experiment referred to in 144. The following significant statement occurs among the conclusions of the author: "In former discussions those who advocated applied science have been forced to take the defensive. While the data here obtained do not finally settle the question of the relative merits of the pure-science and applied-science approach to secondary-school zoölogy, they do shift the burden of proof to those who advocate the cultural approach."

171. "Development of the Textbook of Agriculture in North America." L. H. Barley. U.S. Department of Agriculture, Office of Experiment Stations, Annual Report for I903, 689-712.

This article is based on a similar contribution to Book Reviews, VII (1899), No. 2, 43-53, but is greatly extended. An abridged discussion of this subject by the same author is found in the Cyclopedia of American Agriculture, IV (1909), 379-85.

A historical account of the development of the textbook of agriculture in North America is given, and is followed by an annotated chronological bibliography of fory-nine titles, including the first textbook (1824) and all others known to the writer at the time of publication (1903).

I72. "Textbooks of Agriculture." B. M. Davis. Nature-Study Review, V (I909), No. 9, 244-48.

Four types of textbooks are briefly discussed. These are illustrated by reviews of seven textbooks.

I73. "Some Textbooks for Secondary-School Agriculture." C. H. RoBison. Nature-Study Review, III (1907), No. 6, 180-85.

The article is introduced by a general discussion of the movement for agricultural education, and is followed by a detailed account and criticism of three well-known textbooks representing three distinct types.

174. The School and Farm. Chardes A. Eggert. Chicago: W. M. Welch \& Co. (1902), 279.

The book is divided into six parts: Basis and Conditions of Farming; Field Crops; Animals on the Farm; Forest; Science and Agriculture; Rural Scenery. Each part is divided into chapters, e.g., Part II into Raising and Rotation of Field Crops; Grain Crops, Corn; Grass, Clover, and Hay ; Root Crops, Potatoes; Value of Different Fertilizers; Silos and Ensilage.

175. First Principles of Agriculture. Emmett S. Goff and D. D. Mayne. New York: American Book Co. (I904), 248.

"The first part is based on experiments which may be performed in the school or at home. A summary entitled 'What We Have Learned' has been placed at the close of each chapter. These summaries furnish definite statements for pupils to learn, and may be used by the teacher as a basis for drill work."

There are forty chapters: Dead and Living Matter; Soil and Soil Water; Plant and Water; How Plants Grow; Ideal Soil; Soil Fertility: Humus; Clover; Rotation; Saving Soil Moisture; Plant Parasites; Seeds and Soil Water; Air and Germination; Seed Testing; How Seeds Come Up; Value of Large Sceds: Budding; Transplanting; Plant Improvement; The Flower; Crop and Weeds; Garden Orchard; Insect Destroyers; Animal Husbandry; Dairy Breeds; Beef Breeds; Feeding; Horses; Shcep; Swine; 
Poultry; Bee-keeping; Home and School Grounds. There is an Appendix of fifteen pages, including various tables, and also directions for Babcock milk-testing.

176. Agriculture through the Laboratory and School Garden. C. R. JACKSoN and Mrs. L. S. Daugherty. New York: Orange Judd Co. (1905), $\mathrm{x}+403$.

The author's aim is to "present actual experimental work in every phase of the subject possible." Contents: Nature and Formation of the Soil; Classification and Physical Properties of Soils; Soil Moisture and Preparation of the Soil; The Soil as Related to Plants; Leguminous Plants; Principles of Feeding; Rotation of Crops; Milk and Its Care; Propagation of Plants; Improvement of Plants; Enemies of Plants; Ornamentation of Grounds. General References, Agricultural Publications, List of Experiment Stations, Publishing Houses, and Glossary follow. For critical summary of his book see 148 .

177. Elementary Agriculture with Practical Arithmetic. K. L. HaTcH and J. A. Haselwood. Chicago: Row, Peterson \& Co. (I905), I98.

Each chapter is followed by a set of practical farm problems to be used as exercises for arithmetic class. Contents: Growth of Plants; Plant Water; Plant Foods; Soil; Soil and Crops; Wearing the Soil ; Legumes; Drainage; The Crop; Insects; Weeds; Farm Stock; Feeding; The Three C's; Dairy; Poultry; Special Crops; Farm Buildings; Accounts; Forestry; Grounds; School Gardening; Home Gardening; Barn Plan and Ventilation.

I78. Elements of Agriculture. J. H. Shepperd and J. C. McDowell. St. Paul: Webb Publishing Co. (1905), 254.

This book is intended especially for use in the Northwestern states. "This course of study follows the seasons: the work on farm crops coming in the fall, that on domestic animals in the winter, and the work on soils and the beautifying of the home and school grounds forms a large part of the course during the spring months."

179. The First Book of Farming. Charles L. Goodrich. New York: Doubleday, Page \& Co. (I905), $x x+259$.

The subject is developed by means of experiments as follows: Roots; Soils; Relation of Soils to Water; Forms of Soil Water; Loss of Soil Water; Soil Temperature; Plant Food in the Soil; Seeds; Seed Planting; Spading and Plowing; Harrowing and Rolling; Leaves; Stems; Flowers; A Fertile Soil; Soil Water; After Cultivation of Crops; Farm Manures; Commercial Fertilizers; Rotation of Crops; Farm Drainage.

I80. Agriculture: Its Fundamental Principles. ANDrew M. Soule and Edna LEe Turpin. Richmond, Va.: B. F. Johnson Pub. Co. (I907), 320.

"The aim of this book is so to state the scientific facts and principles which underlie the processes of agriculture that they will be intelligible and interesting to young people." Contents: The Soil; The Plant; Soil Improvement; Field, Orchard, and Garden Crops; Crop Enemies and Friends; Domestic Animals; Miscellaneous, Including Trees, Tools, Roads, School Gardens, etc. An Appendix giving tables, references, etc., is included. 
18I. Rural School Agriculture. Charles W. Davis. New York: Orange Judd Co. (I907), vii+ 267 .

"This book is a manual of exercises covering many phases of agriculture" as follows: Plants; Soils and Fertilizers; Corn; Wheat and Oats; Cotton; Feeds and Feeding; Milk; Fruits; Home Grounds; Insects; Spraying. There is a Glossary and an Appendix of useful tables.

182. Agriculture for Southern Schools. J. F. Duggar. New York: Macmillan (1908), 355 .

As the title indicates, this book is intended especially for southern schools, the adaptation being the use of the best practices and materials of southern agriculture for illustration.

The first part of the book deals with plant growth, including the plant's relation to the soil. The second part deals with crops, including enemies (the cotton boll-weevil receiving particular attention), animal husbandry, farm machinery. Important reference tables are arranged in an Appendix.

183. Elements of Agriculture. W. C. WeLboRn. New York: Macmillan (Ig08), xvi+359.

This book is prepared for use in southern and western elementary schools. Three phases of the subject are taken up as follows: Crop Production, including the plant and its environment, characteristics of various field crops, soil fertility, etc.; Special Crops, in which the management of each crop is described in detail; Animal Production, including feeding and ration, care of animals, various kinds of farm animals in detail. An Appendix gives a classification of the most common economic plants, plant diseases, and insect enemies of plants and their remedies, score cards for judging, and a Glossary.

184. First Principles of Soil Fertility. Alfred Vivian. New York: Orange Judd Co. (Igo8), 265 .

The book is intended for home reading as well as for school use. It is divided into four parts: Plant Food, Its Nature and Source; Making Potential Plant Food Available; Barnyard Manure; Commercial Fertilizers.

185. Manual of Agriculture for the Common Schools of Illinois. D. O. BARTo. New York: Appleton \& Co. (Igo8), 52.

"The writer has tried to outline in this little guide sets of studies and exercises in agriculture on topics of general importance and interest to farmers in all sections of Illinois." The "sets of exercises" are as follows: What Is a Soil? Water; Demands on Water Supply of the Soil; Saving the Soil Water; Effect of Color on Temperature of Soils; Plant and Essentials of Plant Production; Seed; Testing the Seed; Importance of Fine Tilth; Seed Planting; Roots; Root Tubercles; Inoculating the Soil; Plot Experiments; How Necessary Fertilizers Can Be Obtained; Care of Plot Experiments in Vacation; Studies in Corn; Pollination. Two pages of references are given.

186. One Hundred Lessons in Elementary Agriculture. A. W. Nolan. Morgantown, W.Va.: Acme Publishing Co. (Igo8).

The wide range of topics included in the hundred lessons touches all important phases of agricultural problems. Soils, seeds, gardens, trees, crops, insects, weeds, poultry, foods, birds, machinery, rural civics, and economics-these suggested by titles of prominent lessons-indicate the scope of the book. Much of it is nature-study with agricultural materials and some of it is strictly the technical aspect of the science of agriculture. 
187. Teachers' Manual of Elementary Agriculture, Nature-Study, and Domestic Science. F. E. Thompson, T. S. Parsons, et al. Boston: Ginn \& Co. (rgo8).

This manual was prepared under the direction of the Colorado Teachers' Association. After an introduction dealing with the educational aspects of the subject follow chapters on Soils, Plant Life, School Gardening and Improving School Grounds, Field Crops, Insects and Birds, Live Stock, and Domestic Science. Five pages are devoted to a Bibliography for agriculture and nature-study work.

I88. Agriculture for Common Schools. MARTin L. Fisher and FASSETT A. CotTon. New York: Scribner (I909), xxiii+38I.

The book is divided into five sections as follows: I, Soils; II, Farm Crops; III, Horticulture; IV, Animal Husbandry; V, Dairying. There are several appendices. One of these deals with the teaching of the subject with special reference to correlation with reading, arithmetic, geography, etc.

I89. Agriculture in the Public Schools. Lester S. Ivins. Lebanon, O.: March Bros. (1909), I 56 .

This is a handbook for teachers. It includes suggestions for organization of rural schools, teaching of nature-study and agriculture in rural schools, plans for conducting parents' meetings, public displays of school work, corn, potato, and vegetable growing contests, home, rural, and cityschool flower gardens, and other valuable information that is intended to be helpful to the teacher.

I90. Elements of Agriculture. G. F. WARREN. New York: Macmillan (I909), xxiv +434 .

"This book is intended for use in high schools, academies, and normal schools, and in colleges when only a short time can be given to the subject." The author has attempted to carry out the suggestions of the Committee on Instruction in Agriculture of the Association of American Colleges and Experiment Stations. All important phases of agriculture are discussed in the eighteen chapters that make up the body of the book. The text of each chapter is followed by questions, laboratory exercises, and collateral reading. A summary of chap. v, "The Soil," will illustrate the method of treatment which is typical of each chapter: What Soil Is; Rock Particles of the Soil; Soil Water, Including Irrigation and Drainage; Soil Air; Organic Matter of the Soil; Life in the Soil. The chapter is reviewed by means of twenty-four questions. The following is typical: "Where does a fence post rot most rapidly? Why?" Fifteen excellent laboratory and field exercises give concreteness to the text. Ten references are given in the Collateral reading. There are twenty pages of appendix containing information useful to teacher and pupil.

19I. Elementary Principles of Agriculture. A. M. FERguson and L. L. Lewis. Sherman, Tex.: Ferguson Publishing Co. (rgog), xvi+3r8.

The aim of the book is perhaps best expressed by the authors: "Our own ideas are that the primary object of a text on agriculture, intended for the common schools, is to satisfy the natural interest of all children about the whys of common farm conditions."

The book is in three parts: Part I, deals with the plant, soil diseases of plants, injurious insects, etc.; Part II, with animals, including dairying; Part III, is devoted to special topics, such as home lot, school gardens, forestry, etc. There is an Appendix of nine parts, including references, formulae for sprays, tables of nutrients, rainfall, etc. 


\section{I58 AGRICULTURAL EDUCATION IN PUBLIC SCHOOLS}

192. Practical Agriculture. JoHN W. Wilkinson. New York: American Book Co. (rgo9), 383 .

This is a "brief treatise on agriculture, horticulture, forestry, stock feeding, animal husbandry, and road building." These subjects are discussed in forty-five chapters. In the Appendix of twenty-two pages are found useful tables and references, and a list of apparatus needed for conducting laboratory courses in agriculture.

193. A Practical Arithmetic. F. L. Stevens, Tatt, Butler, and Mrs. F. L. Stevens. New York: Scribner (rgog), ix+386.

In addition to the usual aims sought in arithmetic tests, the authors have included "teaching valuable facts by basing the problems of the book upon problems of real life." The book contains a good collection of interesting and valuable applications of arithmetic to the affairs of farm life. Instead of the hypothetical problems concerning what $A$ and $B$ did, occur such problems as, "If kainit contains $12 \mathrm{~T} / 2$ per cent potash and muriate of potash contains 50 per cent potash, how many pounds of kainit will it take to supply as much potash as 40 pounds of muriate of potash?"

194. Practical Nature-Study and Elementary Agriculture. John M. Coulter, John G. Coulter, and Alice Jean Patterson. New York: Appleton \& Co. (rgo9), ix+354.

This is a manual for use of teachers and normal students. It is divided into four parts. The first part considers the educational aspects of naturestudy and agriculture; the second, "a detailed topical outline by grades and seasons of the materials used in nature-study in the training school at the Illinois State Normal University"; the third, "a sliorter outline for work in the lower grades arranged according to seasons, and leading more directly to agricultural studies of the seventh and eighth grades"; the fourth "comprises certain chapters upon general topics; material which has been found serviceable for teachers whose general science training has been slight or lacking entirely."

195. Agriculture for Schools of the Pacific Slope. E. W. HIlgard and W. J. Osterhout. New York: Macmillan (Igro), xix +428.

This book contains twenty-three chapters devoted to plants and their cultivation. Five chapters are devoted to animals. This emphasis on plants is doubtless due to the fact that horticulture is one of the chief agricultural industries of the Pacific Slope. The living plant in all its relations receives more attention than is usual in an agricultural textbook. The book could very well be used as a textbook of botany. It is illustrated by 209 good illustrations. Elementary School Agriculture (1911), a teacher's manual to accompany this text, has been prepared by E. B. ВАвсоск and C. A. Stebins.

196. Domesticated Animals and Plants. F. Davenport. Boston: Ginn \& Co. (I9ro), xiv $+32 r$.

This is a brief treatise upon the origin and development of domestic races with special reference to the methods of improvement. It is in two parts, one "constituting a brief course covering the essential principles that are fundamental to an understanding of hereditary transmission and of the business of plant and animal improvement"; the other deals with the origin of domesticated races. 
197. Farm Development. Willetr M. Hayes. New York: Orange Judd Co. (r9ro), $x i i+39$ r.

This is "an introductory book in agriculture, including a discussion of soils, selecting and planning farms, subduing the fields, drainage, irrigation, roads, fences, together with introductory chapters concerning farm business, and the relations of the general science of agriculture."

198. Manual of Agriculture: Soils and Crops. D. O. BARTo. Boston: D. C. Heath \& Co. (I9II), $x i+492$.

This manual is a series of laboratory and field experiments in two parts, one relating to soils; the other to crops. The work included is considered sufficient to cover one year of the high-school course in agriculture, and is intended to "offer training" in science comparable to that furnished by the other science courses in good high schools."

199. Outlines of Agriculture for Rural Schools. C. M. Evans. Chicago: W. M. Welch Mfg. Co. (I9ro), 3 I.

A year's work is outlined for rural schools with one lesson each week.

200. Fundamentals of Agriculture. James Edward Halligan. Boston: D. C. Heath \& Co. (Igrr), xi+492.

"Every subject in this book is written by an expert in his line. This idea was carried out in order to furnish the student with the best information that could be obtained. The editor thought it would be better to have authorities treat of the various topics rather than write the book alone, as there are very few men competent enough to warrant their writing the best book on agriculture." Thirty-three experts in various fields of agriculture have contributed.

201. An Introduction to Agriculture. A. A. Upham. New York: Appleton $\&$ Co. (I9II), xi+270.

The aim of the book is "to touch those matters which would be most useful to the pupils in our rural schools, and especially to give the underlying theory for many farm processes and practices." There are twentyone chapters and an Appendix. All of the usual subjects of agriculture are covered in these chapters, and the Appendix contains references and a number of useful tables.

202. Beginnings of Agriculture. Albert R. MANN. New York: Macmillan, (IgII), $\mathrm{x}+3 \mathrm{I} 7$.

"This book is designed for the purpose of introducing the study of agriculture into the seventh and eighth grades of our elementary schools. The book is founded on the suggestions in the Report of the Committec on Industrial Education in Schools for Rural Communities of the National Education Association. It has been the aim of the author to cover the work very largely in a nature-study spirit, by which it is meant that the pupil shall be brought into as close touch as possible with the actual farms, soils, crops, animals and affairs." There are four parts: I, The Affairs of Agriculture, eight chapters; II, The Soil, seven chapters; III, Farm Plants, sixteen chapters; IV, Farm Animals, ten chapters. Each chapter is followed by a series of problems dealing concretely with various phases of the subject in text. There are two hundred and forty-one such problems in the book. 



\section{INDEX}

Agriculture, U.S. Department of: agricultural education, Ir; Association of Agricultural Colleges, 8, 64; Bureau of Plant Industry, II; farmers' institutes, I 2; Forest Service, ro; history of, 7; Office of Experiment Stations, 7 , Ir; organization of, 9; Weather Bureau, 9

Agricultural Colleges, 8, 38, III, I26; association of, 8, 64

Agricultural-College high schools, I 20

Agricultural education, U.S. specialist, I2

Agricultural extension, 38, 87, III; publications, 40

Alabama: Agricultural College, 43, 46; district agricultural schools, I 20; Educational Association, 66; Farm Life Club, I08; legislation, 20

American Association of Farmers' Institute Workers, 90

Arithmetic, 128

Arizona, 20

Arkansas: Agricultural College, 43; district agricultural schools, 27, r20; legislation, 20, 27

Bailey, L. H., 38, 47, r19, r27, r30, r3 r

Baltimore County, Md., high school, IOI, I2I

Barnard's Journal of Education, 67

Bishop, E. C., 74

Boys' clubs, 39, 4r, 44, 76, II6, Ir8; agricultural, 42, ro5; corn, ro6

Boy Scouts, III

Brown, Elmer E., I8

Bureau of Education, U.S., I4

Bureau of Plant Industry, U.S., I I

Burkett bill, I6

Butterfield, K. L., 64

California: Agricultural College, 39, 40, 43, 46, 91; high schools: Gardena, I22, Polytechnic, I24, San Diego, r22, Stockton, r22; legislation, 20, 27, 37; State Normal School, 49, 54

Canada, 78

Cecil County, Md., 62

Clapp, Henry L., 62

Claxton, P. P., I8

College entrance, 64, r 26

Colleges, agricultural, 38 , I I 6 , I 26

Colorado: legislation, 20; State Normal School, 54
Columbia College, 7, 95

Columbian Magazine, 68

Commissioner of Agriculture, 85

Commissioner of Education, U.S., r4; state, r9

Committee on Industrial Education, N.E.A., $6 r, 62$

Committee of Twelve, N.E.A., $6 r$

Congressional district schools, $63, x_{20}$

Connecticut: Agricultural College, 46; legislation, 20

Course of study in agriculture, 8

Consolidation, 76

Cornell University, 25, 38, 39, 87, 96; leaflets, I5, I9

Crosby, D. J., I2, 64

Davenport, Eugene, 50

Davis bill, I6, 62, 64

De Fellenburg, 69

Delaware, I9, 43

Delaware County, Ia., I I 2

Demonstration work, government, I I I

Department of Agricultural Education: agricultural colleges, 43, 44; National Education Association, 64; New York, r23; Pennsylvania, 36

Department of Agriculture, U.S., 7

Department of Superintendence, N.E.A., 63

District agricultural schools, 63, I 20

Dunn County School of Agriculture, 62

Educational periodicals, 67

Elementary schools, II 6

Experiment clubs. See Boys' clubs

Experiment Station, Office, of, II

Experiment Station Record, I 2, 83

Extension, agricultural, $38,87,89$, rrr; methods, 38

Farm boys' encampment, 88

Farm Life Club, I08

Farmers': Alliance, 98, 99; bulletins, 9; clubs, 100; institutes, r2, 85, 89; institute specialist, r2, 90 , rro; institutes for young people, I Io

Florida: Agricultural College, 4I; legislation, 20

Forest Service, U.S., Io

Forestry: in agriculture, $\mathrm{Ir}$; in geography, $I x$; in nature-study, $I_{I}$

Franklin, Benjamin, 94 
Gardena (Cal.) high school, I 22

Gardens, school, I1, 14, 52, 102

Georgia: Agricultural College, 43, 46; district agricultural schools, 63,120 ; legislation, 20; Teachers'Association, 66 Grange, 98

\section{Hamilton, John, 12}

Harris, W. T., 59

Harvard, 7

Harvey, L. D., 66

Hatch act, 7

Hays, Willet M., I3, 66

High schools, agriculture in: agriculturalcollege, 120; city, I22; county, 120; district, I20; normal, I24; state aid, I23; technical, I24; village-township, I 2 I

Hinckley State High School, Minnesota, I 23

Holbrook, Josiah, 68

Hopwyl, 70

Horticultural Society: of Iowa, ror; of Massachusetts, I02; of New Jersey, I00

Idaho: Agricultural College, 43; legislation, $21,28,37$

Illinois: Agricultural College, 39, 40, 43, 46; Grange, 99; Industrial League, 96; legislation, 21; School News, 74; State Fair, 88; state normal schools, $49,53,54$

Indiana: Agricultural College, 39, 43; legislation, $2 \mathbf{I}$

Industrial education, N.E.A., 60, $6 \mathrm{r}$

Industrial League of Illinois, 96

International Congress of Education, 60

Iowa: Agricultural College, 43; corn clubs, 112, I1 3 ; legislation, $20,28,37$

John Swaney Consolidated School, Illinois, 62

Johnson State Normal School, Vermont, 48

Journal of Education, 67

Junior Demonstration Work, I $\mathrm{x}$, 108

Kansas: Agricultural College, 39, 4I, 43, 46; boys' clubs, I06; legislation, $2 \mathrm{I}$, 28, 37; Rural Life Scouts, II I; State Normal School, 54

Kentucky, I8, 2 I

Keokuk, Ia., 18, 2 I

Kern, O. J., 76

Kingsville Township, Ohio, 76

Knapp, S. A., 108

Laboratory exercises, 130

Land Grant act, 14, 96
Lethe, S. C., 68

Louisiana: Agricultural College, 43; agricultural high schools, 28; boys' clubs, 4I, 104; legislation, 2 I, 28, 37

Macdonald Movement, 79

Maine: Agricultural College, 43; legislation, 21,29

Manual training, 60

Martin, O. B., IO7

Maryland: Baltimore County Agricultural High School, ror; legislation, 21, 29, 37

Massachusetts: Agricultural College, 40 , 43, 46; Agricultural Society, 96; Board of Agriculture, 87; Board of Education, I 25; Horticultural Society, IO2; legislation, 2I, 29, 37; project plan, 29, I 25

Miami University, 56

Michigan: Agricultural College, 40, 43; agricultural extension, 91; Agricultural Society, 96; legislation, 22, 30; State Association of Farmers' Clubs, 100; State Board of Agriculture, 85; state normal schools, 49

Minnesota: Agricultural College, 40, 46; high schools, 31, I20, 123; legislation, 22, 31, 37; State Fair, 88; state normal schools, 49

Mississippi: Agricultural College, 42, 43,46 ; boys' clubs, 107; legislation, 22, 32, 37

Missouri: Agricultural College, 43, 44, 46; Board of Agriculture, 87; legislation, 22; state normal schools, 53, 54, 55 , I 24

Montana, 22, 32, 37

Moore, Jerry, 107

Morrill act, 7, 15

National Committee for Agricultural Education, N.E.A., 62

National Education Association, 58

National Teachers' Association, ${ }^{8} 8$

Nature-Sludy Review, 72, 73

Nebraska: Agricultural College, 42, 43; boys' clubs, 42, 74; legislation, 22, 32; State Fair, 87; state normal schools, 53; Ncbraska Teacher, 74

Nelson act, 15

Nevada, 32

New Hampshire: Agricultural College, 39; legislation, 23,33

New Jersey: Agricultural College, 46; Horticultural Society, Ioo; legislation, $23,33,37$

New Mexico, 23 
New York: Agricultural College, 37, 4I, 45, 46, 96; Agricultural Society, 95, 96; Department of Agriculture, 87, 92; Department of Education, 92, I23; high schools, 12.3 ; legislation, 23,25 , 26, 33, 37, I23; Nixon law, 25; state normal schools, $49,50,5 \mathrm{I}, 53$

Nixon law, 25

Normal Agricultural Society, 53

North Carolina: Agricultural College, 43, 46; legislation, 23, 33, 37; State Normal School, 49

North Dakota: Agricultural College, 46, 92; legislation, $23,34,37$

Office of Experiment Stations, U.S., I I

Ohio: Agricultural College, 40, 43, 46; boys' clubs, I05; district supervisor, 35 ; legislation, $23,35,37$, I 17 ; New Holland high school, I2I; State Normal College, 56

Oklahoma: Agricultural College, 43, 46, 92; district agricultural schools, I 20; legislation, 23; State Fair, 88; state normal schools, 49

Oregon: Agricultural College, 43, 46; legislation, 23; state normal schools, 47

Oswego, 69

Otwell's Farmer Boy, II 3

Otwell, W. B., II3

Page bill, I 8, 64

Pennsylvania: Agricultural College, 39, 40, 43, 46; Agricultural Society, 95: legislation, $23,36,37$; state normal schools, 49,50

Periodical literature, 75

Pestalozzi, 69

Phenological studies, Io

Philadelphia agricultural societies, 94

Philbrook, John D., 59

Pickering, Timothy, 94

Porter, John A., 68

Rhode Island, 39, 43, 46

Rock Hill State Normal School, 49

Rural and agricultural education, N.E.A., $62,64,65$

Rural high school, I I 5

Rural Life Scouts, I I I

Rural-school curriculum, I I 7

Rural-school problem, 60

St. Louis Exposition, boy's' exhibits, II 3

School Agriculture, 73

School gardens, I1, I4, 52, 73, 102

School News, 74

School Science and Mathematics, 72
Schools, secondary, 110

Schools, state normal: California, 49, 53, 54; Colorado, 54; Illinois, 49, 53, 54 ; Iowa, 49; Kansas, 49, 54; Massachusetts, 53; Michigan, 49; Minnesota, 49; Missouri, 49, 53, 54, 55; Nebraska, 49, 53; New Jersey, 53; New York, 49, 50; North Carolina, 49; Ohio, 49, 56; Oklahoma, 49; Oregon, 47; Pennsylvania, 49, 5०; South Carolina, 49; Utah, 49; Vermont, 48; Virginia, 55; Wyoming, 48

Seed collection, II

South Carolina: Agricultural Society, 94; boys' clubs, I07; legislation, 23;

State Department of Agriculture, 48; State Normal School, 49

South Dakota, 24

State fairs, 88,89

State organizations for agriculture, 85

State teachers' associations, 66

Summary of legislation, 27,37

Summer schools, 46

Teachers' associations, 58

'Tennessee: Agricultural College, 40, 43, 46 ; legislation, 24

Texas, $24,36,37$

True, A. C., 66

Turner, Jonathan B., 97

United States: Bureau of Education, I4; Department of Agriculture, 7

University of Pennsylvania, 95

Utah: Agricultural College, 43, 46; legislation, 24, 36, 37; State Normal School, 49

Vermont: Agricultural College, 43, 46; legislation, 24, 36; State Normal School, 48, 49

Virginia, 24, 55

Washington: Agricultural College, 43, 46; legislation, 24, 36, 37 Washington, George, 94

Waterford High School, Pa., 62

Wehrli, 69

West Virginia: Agricultural College, 39, $43, \Delta 6,92$; legislation, 24

Winnebago County, Ill., 76

Wisconsin: Agricultural College, 43, 46, 92; agricultural high schools, I 20; legislation, 24, 36, 37

Wyoming: Agricultural College, 46 ; legislation, 24; state normal schools, 48

Yale, 7

Y.M.C..., I06, II 2 



from which it was borrowed.

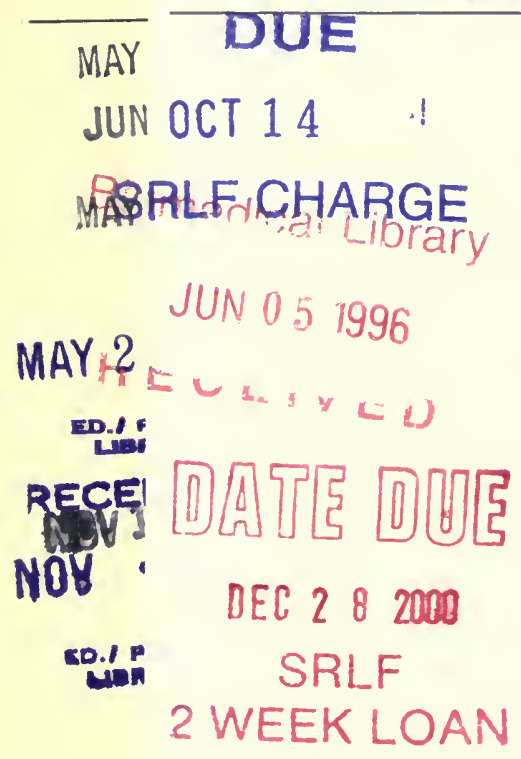


A $001036836 \quad 3$
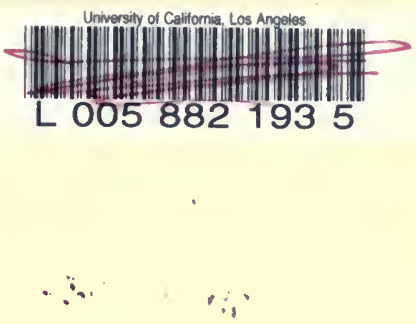

\section{Education \\ Library \\ $\mathrm{S}$ \\ 533 \\ D29a}

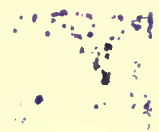

?4. 
